UNIVERSIDADE DE SÃO PAULO

INSTITUTO DE PSICOLOGIA

LUCIANA BITTENCOURT FEVORINI

\title{
O envolvimento dos pais na educação escolar dos filhos: um estudo exploratório
}

SÃO PAULO 


\section{O envolvimento dos pais na educação escolar dos filhos: um estudo exploratório.}

Tese apresentada ao Instituto de Psicologia da Universidade de São Paulo para a obtenção do título em doutora em psicologia.

Área de concentração: Psicologia Escolar e do Desenvolvimento Humano.

Orientador: Professor Associado Dr. José Fernando Bitencourt Lomônaco.

SÃO PAULO 
AUTORIZO A REPRODUÇÃO E DIVULGAÇÃO TOTAL OU PARCIAL DESTE TRABALHO, POR QUALQUER MEIO CONVENCIONAL OU ELETRÔNICO, PARA FINS DE ESTUDO E PESQUISA, DESDE QUE CITADA A FONTE.

Catalogação na publicação

Serviço de Biblioteca e Documentação

Instituto de Psicologia da Universidade de São Paulo

Fevorini, Luciana Bittencourt.

O envolvimento dos pais na educação escolar dos filhos: um estudo exploratório / Luciana Bittencourt Fevorini; orientador José Fernando Bitencourt Lomônaco. -- São Paulo, 2009.

$179 \mathrm{p}$.

Tese (Doutorado - Programa de Pós-Graduação em Psicologia. Área de Concentração: Psicologia Escolar e do Desenvolvimento Humano) - Instituto de Psicologia da Universidade de São Paulo.

1. Família 2. Crise da família 3. Relações pais-escola 4. Rendimento escolar I. Título.

HQ10 
Luciana Bittencourt Fevorini

O envolvimento dos pais na educação escolar dos filhos:

um estudo exploratório.

Tese apresentada ao Instituto de Psicologia da Universidade de São Paulo, para a obtenção do título de doutora em psicologia.

Área de concentração: Psicologia Escolar e do Desenvolvimento Humano.

Aprovado em:

Banca Examinadora

Prof. Dr.

Instituição:

Assinatura:

Prof. Dr.

Instituição:

Assinatura:

Prof. Dr.

Instituição:

Assinatura:

Prof. Dr.

Instituição:

Assinatura:

Prof. Dr.

Instituição:

Assinatura: 


\section{AGRADECIMENTOS}

Ao meu orientador, Professor Associado Doutor José Fernando Bitencourt Lomônaco, pela tranquilidade na condução do trabalho, sempre com orientações sensatas e precisas.

Aos membros da Banca Examinadora do Exame Geral de Qualificação, Professora Doutora Belinda Pilcher Haber Mandebaum e Professora Heloísa Szymanski, pelas sugestões pertinentes e oportunas.

Aos diretores e coordenadores das escolas pesquisadas, pela abertura e pela confiança depositada em meu trabalho.

Aos pais e mães entrevistados, pela disponibilidade e pela generosidade com que receberam a mim e as minhas questões.

A toda comunidade do Colégio Equipe, representada aqui pela Ausonia Donato e por Luís Márcio Barbosa, sempre me desafiando a aprimorar minha prática profissional.

À minha família: pai, mãe, irmãs, pelo apoio.

Ao Gílson, meu marido, pelo rigor nas correções das vírgulas, pontos, concordância, regência, além de comentários e sugestões instigantes, mas, acima de tudo, pelo companheiro que é.

Ao Gil, filho querido, pelo carinho! 


\section{Epígrafe}

"Ser capaz de "ir além das informações" dadas para se "descobrir as coisas" é uma das poucas eternas alegrias da vida".

Jerome Bruner 


\section{RE S U M O}

FEVORINI, L. B. O envolvimento dos pais na educação escolar dos filhos: um estudo exploratório. 2009178 p. Tese (Doutorado) - Instituto de Psicologia, Universidade de São Paulo, São Paulo, 2009.

O presente estudo procurou avaliar o grau de envolvimento dos pais, das classes sociais média-alta e alta na educação escolar dos filhos. Para isso, algumas escolas que atendem a esse público foram procuradas com a solicitação da permissão de conversar com algumas das famílias de seus alunos. A seleção das escolas particulares da cidade de São Paulo foi feita a partir dos resultados de seus alunos no exame do ENEM (Exame Nacional do Ensino Médio): escolheu-se uma escola com boa colocação (entre as dez primeiras), uma com colocação média (entre as 60 primeiras) e uma que não obteve bons resultados. $O$ instrumento para a coleta de dados foi a entrevista semi-estruturada com casais de pais ou apenas com a mãe. Foram realizadas 13 entrevistas, totalizando 21 entrevistados. A análise dos resultados revelou que esses pais e mães, contrariando estereótipos e/ou crenças comuns a respeito do envolvimento dos pais na vida escolar dos filhos, mostraramse muito envolvidos com a escolaridade dos filhos e afirmaram não delegar à escola tarefas como a formação de valores e o estímulo à disciplina. A ideia de diferentes estudiosos de que a família vive uma crise de valores e de autoridade e que delega à escola tarefas que não se sente capaz de realizar não foi corroborada neste estudo. Em face dos resultados, foram sugeridos alguns caminhos para que a escola possa desenvolver uma parceria efetiva com as famílias de seus alunos: estabelecer relações simétricas e de corresponsabilidade com os pais e oferecer a eles espaços de debate e reflexão sobre questões que vivenciam no dia-a-dia com seus filhos.

Palavras-chaves: família; crise da família; relações pais-escola; rendimento escolar. 


\begin{abstract}
FEVORINI, L. B. Parents involvement in children's learning: an exploratory study. 2009. $178 \mathrm{f}$. Thesis (Doctoral) - Instituto de Psicologia, Universidade de São Paulo, São Paulo, 2009.

This study aimed to assess the degree of involvement of both high middle-class and upper class families in their children's education. The selection of private schools in São Paulo, SP, was based on students' performance at ENEM (National High School Standardized Examination). Three kinds of schools were chosen: one ranking among the top ten first, one from the sixty top first, and one whose performance was below average. A semi-structured interview was used as the instrument for the collection of data. Thirteen interviews with couples or with just the mother were carried out, totaling 21 interviewees. The analysis of the results shows that those parents, contradicting stereotypes and widespread beliefs about parent involvement in their children's learning process, are in fact deeply involved, and do not delegate the school to teach students such things as moral values and discipline. The idea shared by various scholars that families are at present undergoing both a value and an authority crisis and that they expect their children's school to do what they feel unable to do has not been corroborated by this study. In face of the results obtained, some suggestions have been put forward on how the school might develop an effective partnership with students' families: establishing symmetric and coresponsible relationships with parents and offering them an opportunity to stir up debate and reflection on the issues they experience with their children on an everyday basis.
\end{abstract}

Keywords: family; family crises; parent school relationship; academic achievement. 


\section{SUMÁRIO}

APRESENTAÇÃO

\section{CAPÍTULO 1}

FAMÍLIA E ESCOLA: UMA INTEGRAÇÃO NECESSÁRIA................................... 17

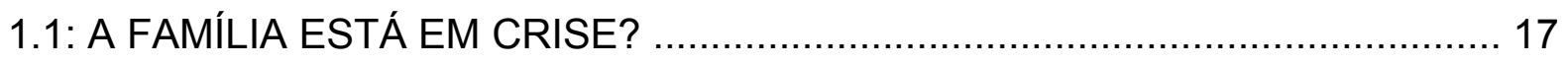

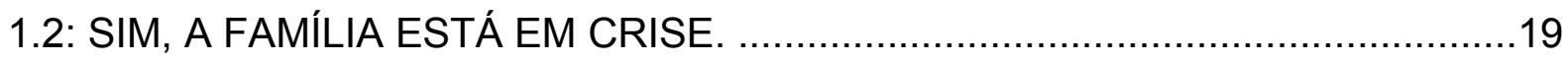

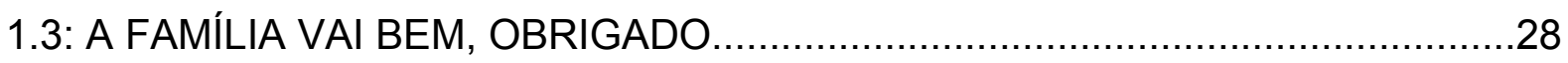

1.4: CONFLITOS E INCERTEZAS NA RELAÇÃO FAMÍLIA-ESCOLA......................31

1.5: QUANDO A ESCOLA TAMBÉM NÃO CUMPRE SEU PAPEL: A FORTE TENDÊNCIA DE RESPONSABILIZAR AS FAMÍLIAS.........................................34

1.6: FAMÍLIA E ESCOLA: PARCERIA E CORRESPONSABILIDADE......................38

1.7: OBJETIVOS:

\section{CAPÍTULO 2:}

MÉTODO

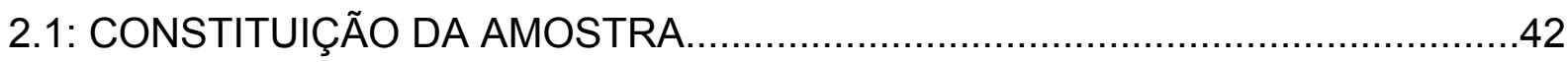

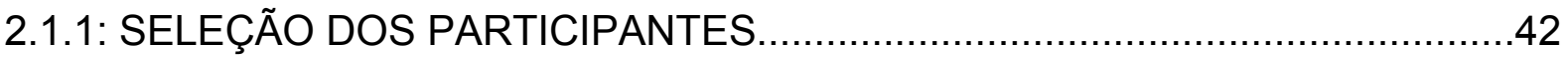

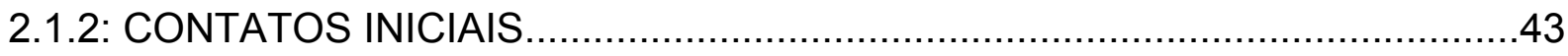

2.1.3: CRITÉRIOS DE SELEÇÃO DAS ESCOLAS...............................................44

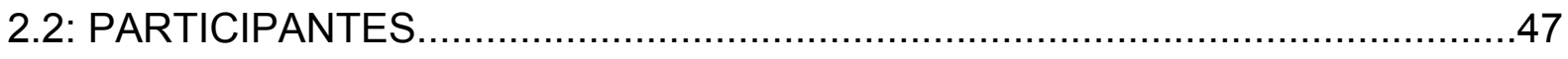

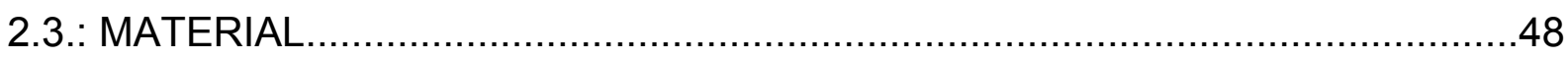

2.4. PROCEDIMENTO 


\section{CAPÍTULO 3:}

RESULTADOS

3.1: ETAPAS DA ANÁLISE DOS RESULTADOS .52

3.2: A IMPORTÂNCIA E OS CRITÉRIOS DA ESCOLHA DA ESCOLA. 68

3.3: PAIS CULPADOS E PERMISSIVOS QUE DELEGAM TODAS AS FUNÇÕES EDUCATIVAS PARA A ESCOLA: UMA GENERALIZAÇÃO INDEVIDA.

3.4: O ACOMPANHAMENTO DA VIDA ESCOLAR DOS FILHOS PELOS PAIS NEM SEMPRE LEVA AO SUCESSO ACADÊMICO.

3.5: O INTERESSE DOS PAIS ACOMPANHA TODA A VIDA ESCOLAR DOS

FILHOS. 83

3.6: AFINAL, O QUE OS PAIS ESPERAM DA ESCOLA? 85

3.7: O QUE OS PAIS CRITICAM NAS ESCOLAS? 91

3.8: REUNIÃO DE PAIS. .93

\section{CAPÍTULO 4:}

DISCUSSÃO. 100

4.1: O PERIGO DAS GENERALIZAÇÕES. 100

4.2: NOVAS PERSPECTIVAS PARA A PARCERIA FAMÍLIA-ESCOLA 102

4.3: IDEIAS PARA APRIMORAR AS REUNIÕES DE PAIS 108

4.4: SOBRE ALGUMAS POLÍTICAS PÚBLICAS DE INTEGRAÇÃO FAMÍLIAESCOLA.

4.5: DE VOLTA AO INÍCIO.

4.6: CONSIDERAÇÕES FINAIS: AS LIMITAÇÕES DO TRABALHO.

REFERÊNCIAS BIBLIOGRÁFICAS

ANEXO A

ANEXO B.

ANEXO C. 


\section{Apresentação}

Por que decidi estudar a relação família-escola? Uma forte razão para essa iniciativa decorre de minha experiência profissional. Como orientadora educacional e pedagógica do Colégio Equipe, escola particular de classe média de São Paulo, sou responsável por acompanhar e intervir no planejamento de ensino dos professores, por acompanhar o processo de aprendizagem dos alunos e por fazer contato com as famílias para informar-Ihes como está ocorrendo esse processo, tanto individualmente quanto coletivamente. Nessa tarefa de representar a escola para as famílias e de trazer informações e questões das famílias para a escola é que me deparo com dificuldades e nebulosidades...

Se há definições claras de ensino e de aprendizagem pelas quais devo me pautar para orientar minha atuação com professores e alunos, o mesmo não ocorre no trabalho que desenvolvo com os pais. Além dos aspectos informativos e de esclarecimento sobre questões pedagógicas, percebo que não há, no contexto educacional em que atuo (e, talvez, no contexto educacional como um todo), clareza sobre o papel que a escola deve desempenhar diante das famílias. Como partilhar com as famílias a formação de crianças e jovens? Há um papel formativo também para elas? Se sim, como deve ser desenvolvido? Acredito que é exatamente por essa indefinição que a relação família-escola é muitas vezes marcada, se não por conflitos, por incômodos de ambas as partes. E foi com o objetivo de entender melhor a relação família-escola, de me aprofundar nessas questões e, também, de aprimorar minha prática profissional que iniciei este trabalho de pesquisa.

Há uma ideia, muito difundida nas escolas e nos meios de comunicação, de que o sucesso escolar depende do valor atribuído pelas famílias ao estudo e à decorrente dedicação a ele. Cláudio Moura de Castro, economista e articulista da Revista Veja (10 de novembro de 2004 , p. 20), num artigo intitulado "A vovó na janela", por exemplo, afirma que o bom resultado dos coreanos em exames internacionais sobre a aprendizagem de leitura é devido à enorme importância que eles atribuem à educação, o que leva as avós a vigiarem, pelas janelas, o comportamento dos netos nas salas de aula. A partir das leituras iniciais para desenvolver este trabalho, encontrei vários estudos indicando que, de fato, o acompanhamento da vida escolar dos filhos pelos pais é um fator importante para a aprendizagem e para o sucesso 
acadêmico de crianças e jovens (PINHEIRO, 2007; POLONIA; DESSEN, 2005; PEREZ, 2004; CHECHIA, 2002; MARQUES, 2002; FRAIMAN, 1997). Pais que adotam em casa uma postura interessada nas atividades que os filhos desenvolvem na escola e participam de eventos organizados por ela, tais como reunião de pais ou mostra de trabalhos, etc., parecem influenciar muito positivamente o progresso escolar de seus filhos. Há pesquisas indicando que, mesmo numa boa instituição escolar, com bons programas curriculares, a aprendizagem do aluno só se evidencia quando ele tem a atenção e o acompanhamento dos pais (POLONIA; DESSEN, 2005).

Os estudos (LOPEZ 2002; MARQUES, 2002; PARO, 2000; SIRAJ-BLATCHFORD, 1999) apontam inclusive para a necessidade de a escola incentivar e favorecer a participação da família na vida escolar dos filhos pois, quando família e escola estabelecem uma boa relação, as condições são melhores para o aprendizado dos alunos. Paro (2000), por exemplo, opina que, para a escola funcionar bem, precisa da adesão de seus usuários, não só alunos, mas também pais e responsáveis. Também Lopez (2002) acredita que a eficiência da educação escolar depende do grau de implicação e participação dos pais. Nesse mesmo sentido, Bhering e SirajBlatchford (1999) apontam que a falta de contato produtivo entre família e escola pode ser um dos fatores determinantes para a má situação da educação brasileira. $\mathrm{E}$ Marques afirma que

O desenvolvimento e a educação da criança dependem sobretudo do esforço comum das esferas sobrepostas que constituem o mundo da criança. Quando estas esferas comunicam e se relacionam de forma positiva, cria-se um ambiente ecológico favorável ao desenvolvimento. Quando estas esferas estão de costas voltadas, perseguem objetivos opostos ou comungam valores conflitantes, estamos perante um ambiente que dificulta o desenvolvimento da criança $(2002$, p. 3).

Em função disso "[...] a relação família-escola vem sendo incentivada pelas políticas públicas e apontada como fundamental para uma escolarização bem sucedida" (RIBEIRO, 2006, p. 386). Nas conclusões do "Resumo Técnico Executivo da Pesquisa Nacional Qualidade da Educação: A escola pública na opinião dos pais" está dito: 
A pesquisa apontou para um desejo dos pais ou responsáveis em intensificar a relação família-escola. Essa intensificação pode ser estratégica na elevação da qualidade do aprendizado. [...] os pais mantêm expectativas de uma participação maior e mais abrangente. Ao que indicam os resultados, as reuniões de pais e professores, tornando-se mais frequentes, podem se constituir um instrumento efetivo de interação de escolas e famílias (PACHECO e ARAÚJO, 2005, p. 19 e 20).

Há em São Paulo o programa "Escola da Família", que incentiva as escolas estaduais a abrirem seus prédios nos fins de semana e oferecer atividades esportivas, culturais e relacionadas à saúde para a comunidade. Também foi lançada por uma grande rede de TV, já há algum tempo, uma campanha, denominada "Amigos da Escola", que incentiva a população a fazer trabalhos voluntários nas escolas públicas. Embora ainda não se tenha tido contato com muitas pesquisas sobre o impacto efetivo dessas iniciativas no aproveitamento escolar, de tempos em tempos os próprios veículos de comunicação divulgam alguns dos efeitos positivos desses programas: a aproximação da comunidade com a escola e a diminuição da violência nas relações entre alunos e entre alunos e professores.

Não obstante a sua relevância, parece que o tema despertou o interesse de pesquisadores no Brasil apenas nas últimas décadas. Romanelli, Nogueira e Zago (2003) fizeram um levantamento em quatro números temáticos de periódicos científicos de circulação nacional da área de Educação, publicados entre 1980 e 1990, e encontraram apenas três artigos, num total de 37, que abordavam a família e sua relação com a vida escolar dos filhos. Consideram que não há uma sistematização na produção brasileira sobre essa temática, o que dificulta avaliar a importância que está assumindo na produção contemporânea. No meu próprio levantamento encontrei, entre dissertações e teses da Universidade de São Paulo em todas as suas unidades, de 2002 até 2008, cinco trabalhos abordando a relação família-escola. Já na PUC de São Paulo, essa temática parece despertar mais interesse, pois foram encontrados dez trabalhos nesse mesmo período, ou seja, o dobro da produção da USP. Mas, ainda assim, não é uma produção muito extensa.

A revisão bibliográfica realizada por Gasonato (2007) aponta diferentes enfoques nos trabalhos e nas pesquisas sobre a relação família-escola: importância do envolvimento familiar no rendimento escolar das crianças e jovens; relações entre 
classes sociais e sucesso ou fracasso escolar; estudo das significações da educação escolar; continuidade e descontinuidade no processo educativo entre casa e escola; preconceitos de educadores a respeito das famílias de seus alunos. Entretanto, a partir do seu levantamento, Gasonato considera poucos os trabalhos cujo enfoque seja as famílias e suas expectativas em relação à educação escolar dos filhos e pergunta: "[...] e, quanto aos pais, quais seriam os seus pensamentos? O que as famílias esperam e podem esperar da escola? Quais são as suas expectativas em relação à escola e à formação dos seus filhos?" (p. 12). Também, segundo Oliveira (2002), são poucos os estudos que esclarecem como a integração família-escola deve ser promovida pela escola, ou seja, que indicam caminhos para uma parceira efetiva ${ }^{1}$. Nessas duas direções o presente trabalho pretende se desenvolver: aprofundar a investigação sobre o que os pais esperam da educação escolar e elaborar princípios para a escola estabelecer vínculos de cooperação com a comunidade de pais.

A opção de me restringir às camadas médias $^{2}$ também foi devido à minha experiência profissional e com o intuito de me aprofundar na caracterização e no estudo de uma realidade social e cultural na qual já estou inserida profissionalmente. Mas, também, porque esse segmento não parece despertar muito o interesse dos pesquisadores em educação do país. Paixão afirma que "seria necessário mapear resultados de pesquisas realizadas no Brasil, sistematizando informações que apontam para a compreensão do problema quando o foco são as camadas médias e a elite" (2007, p. 43). Segundo a pesquisadora Maria Alice Nogueira, há uma "[...] imensa lacuna - para não dizer ausência total - na literatura científica de análises sobre as práticas educativas nas classes médias brasileiras" (1995, p. 10), "o tema constitui território ainda a ser explorado" (2004, p. 26). Para ela, o desconhecimento das condutas escolares das classes relativamente favorecidas e das favorecidas impede a compreensão, de forma mais global, da escolaridade das classes

\footnotetext{
${ }^{1}$ Uma exceção neste contexto é o trabalho desenvolvido por Szymanski (2000) que será considerado posteriormente.

${ }^{2}$ Não cabe neste trabalho uma discussão sobre como caracterizar classes médias e médias altas da população, uma vez que o enfoque é nas práticas educativas. Deste modo, o termo vai indicar "àquelas famílias que se caracterizam pela posse de um certo capital cultural e por ocupações de nível superior [...]" (NOGUEIRA, 1995, p. 14)
} 
populares, mais sistematicamente pesquisadas, pois diminui as possibilidades de comparação.

Há também outro fator que foi se tornando mais claro a partir de leituras e do próprio trabalho de campo: é nas camadas médias da sociedade, com alto capital cultural, como define Bourdieu ${ }^{3}$, ou seja, com bom nível de informação e cultura, que o sucesso escolar é mais frequente. As camadas médias "têm como traço central e mais característico o fato de atribuírem à escola um lugar central em seus projetos futuros, construídos em longo prazo [...] e, com esse fim, mobilizam amplos recursos (em tempo, energia e meios financeiros) a serviço de uma elevada ambição escolar" (NOGUEIRA, 1995, p.12). Essa ambição e essa adesão à escola, segundo Nogueira (1991), advêm da percepção de que ela é um possível canal de manutenção e até mesmo de êxito social. Sendo assim, com suas condições materiais, os pais optam por pagar e, portanto, por escolher a escola em que seus filhos vão estudar, ou seja, garantem "[...] a consonância entre projeto familiar de educação e orientação pedagógica" (PAIXÂO, 2007, p. 43). Investem mais (em todos os sentidos) na educação dos filhos e, portanto, também têm mais expectativas e são mais exigentes com a qualidade dos serviços prestados pela escola.

Assim, estudar o perfil de famílias preocupadas e envolvidas com a educação dos filhos pode ajudar a compreender o fracasso escolar, sem cair em explicações simplistas e preconceituosas. É muito frequente, principalmente nas escolas públicas, as famílias serem responsabilizadas pelo fracasso escolar dos filhos, sendo ele decorrente da pobreza, baixo grau de escolaridade dos pais, "famílias desestruturadas" ou ainda de atitudes, por parte dos pais, contrárias às prescrições da escola (RIBEIRO, 2006; PATTO, 1997; SZYMANSKI, 2003). Mas, como será explicitado neste trabalho, esse é um problema extremamente complexo. Estudar também os procedimentos que boas instituições de ensino desenvolvem, visando um bom relacionamento com as famílias, pode ser um caminho adequado para descobrir princípios mais amplos que busquem o fortalecimento da relação família-

\footnotetext{
${ }^{3}$ A noção de capital cultural impôs-se, primeiramente, como uma hipótese indispensável para dar conta da desigualdade de desempenho escolar de crianças provenientes das diferentes classes sociais, relacionando o "sucesso escolar", ou seja, os benefícios específicos que as crianças das diferentes classes e frações de classes podem obter no mercado escolar, à distribuição do capital cultural entre as classes e as frações de classe. Este ponto de partida implica em uma ruptura com os pressupostos inerentes, tanto à visão comum que considera o sucesso ou o fracasso escolar como efeitos das "aptidões" naturais, quanto às teorias do capital humano (BOURDIEU, 2001, p. 73).
} 
escola e, consequentemente, a melhoria da qualidade da educação oferecida pelas escolas, inclusive as públicas. 


\section{CAPÍTULO 1}

\section{FAMÍLIA E ESCOLA: UMA INTEGRAÇÃO NECESSÁRIA}

\subsection{A família está em crise?}

Nas últimas décadas, pôde-se observar a ocorrência de muitas mudanças nas configurações familiares. A chamada família nuclear, composta por pai, mãe e filhos, tendo o pai como principal provedor financeiro e a mãe dedicada exclusivamente à educação dos filhos e à administração do lar, parece não ser mais tão comum quanto o era até a segunda metade do século passado, principalmente nas camadas médias e altas da população (HOBSBAWM 1996, ROUDINESCO, 2003, BERGAMASCO 2007; IBGE 2007; FERRY, 2008). Assim, novas formas de relacionamento pessoal apareceram e começaram a ganhar visibilidade: há um aumento de pessoas vivendo juntas sem estarem casadas legalmente ou vivendo sozinhas por opção. Mais mulheres se tornaram chefes de família e, culturalmente, há uma aceitação maior da homossexualidade e, portanto, de casais homossexuais.

Esse fenômeno, se não é mundial, pelo menos tem acontecido "nos países ocidentais desenvolvidos” (HOBSBAWM, 1996, p.315). Hobsbawm (1996), um dos historiadores mais importantes da atualidade, ilustra com dados essas novas configurações familiares. Na Inglaterra, em 1938 houve um divórcio para cada 58 casamentos; em 1980, ocorreu um para cada 2,2 casamentos. O número de pessoas morando sozinhas aumentou nas grandes cidades ocidentais, chegando perto de $50 \%$ da população. Nos Estados Unidos o número de famílias compostas por um casal e filhos caiu de $44 \%$ para 29\% em vinte anos (1960-1980) e na Suécia aproximadamente metade de todos os partos em meados da década de 1980 foi de mulheres solteiras.

Ao mesmo tempo, segundo Hobsbawm, passou a ocorrer, em países como a GrãBretanha e os EUA, a descriminalização de práticas homossexuais em meados da década de 1960. Mas, afirma ele, tudo isso não aconteceu da mesma maneira em todos os países. Na Itália, nos países da Península Ibérica e na América Latina o divórcio era bem menos frequente. Entretanto, onde foi permitido, ele aumentava. 
Aqui no Brasil, segundo dados de 2007 do Instituto Brasileiro de Geografia e Estatística (IBGE), o número de separações e divórcios se manteve relativamente baixo, em torno de 2,0\% nessa mesma época. Só a partir da promulgação do divórcio, em 1977, é que se registrou um aumento para 2,7\%. Entretanto, as últimas estatísticas (2007, IBGE) registraram tanto o aumento no número de casamentos legais como o de divórcios.

Em 2007 foram registrados no Brasil 916006 casamentos. Houve, portanto, aumento de $2,9 \%$ no total de casamentos registrados em relação ao ano anterior. Manteve-se, deste modo, a tendência de crescimento que vem sendo observada desde 2003, decorrente, em grande parte, de iniciativas de formalização de uniões consensuais (Estatísticas do Registro Civil, v. 34, p. 45).

Já as taxas de divórcios em 2007, segundo o IBGE, atingiram seu maior índice desde 1984. Comparando esses dados no período verifica-se um crescimento superior a 200\% - a taxa geral de divórcio foi de 0,46 em 1984 para 1,49 em 2007. "A elevação das taxas de divórcio revela uma gradual mudança de comportamento na sociedade brasileira, que passou a aceitar o divórcio com maior naturalidade e a acessar os serviços de justiça de modo a formalizar as dissoluções (IBGE, 2007, Estatísticas do Registro Civil, v 34, p. 49)".

Os dados da pesquisa Datafolha, publicada em 7 de outubro de 2007, também apontam para o aumento no número de divórcios:

[...] $24 \%$, ou seja, aproximadamente uma entre quatro pessoas no país é filha de um casamento que já acabou [...] O número de filhos de pais separados cresce rápido: na pesquisa feita pelo Datafolha em $199878 \%$ dos entrevistados diziam que seus pais continuavam casados, contra $65 \%$ no ano de 2007 (BERGAMASCO, FOLHA DE SÃO PAULO, Caderno Família, p. 62-64).

Mas será que dados como esses são indicadores de que a instituição familiar está em crise? E, se sim, quais as causas dessa crise? Uma consulta a autores preocupados com essa questão permite verificar que não há consenso entre os vários pensadores. Um número significativo afirma que sim; outros, em menor quantidade, afirmam o contrário: as novas configurações só acentuam o fato de como o viver em família tem 
se tornado importante na nossa sociedade. Uma breve exposição das principais ideias de alguns pensadores que procuraram entender o comportamento das famílias na sociedade pós-capitalismo é apresentado a seguir.

\subsection{Sim, a família está em crise.}

O historiador francês Philippe Ariès $\left(1981^{4}\right)$ afirma que é a partir do final do século XVIII que "a família tornou-se o lugar de uma afeição necessária entre os cônjuges e entre pais e filhos" (p. xi). Só então é que os pais passaram a se interessar pelos seus filhos e as famílias passaram a se organizar em torno deles. Antes elas mantinham laços intensos com a comunidade mais ampla e conservavam uma "enorme sociabilidade" (p. 189). Foi nessa época que surgiu a chamada "família moderna" (p.188), caracterizada como um grupo centrado no casal e nos filhos, isolado da coletividade, em que toda a atenção é voltada para a promoção de todas as crianças igualmente. A família passa a ser não apenas uma instituição para a transmissão de bens e de nome, mas a ter uma função moral e espiritual. Os cuidados dispensados às crianças promoveram uma nova afetividade, e o amor obsessivo aos filhos passou a dominar a sociedade desde então.

[...] a família acabava de se reorganizar em torno da criança e erguia entre ela mesma e a sociedade o muro da vida privada. A família moderna retirou da vida comum não apenas as crianças, mas uma grande parte do tempo e da preocupação dos adultos. Ela correspondeu a uma necessidade de intimidade, e também de identidade: os membros da família se unem pelo sentimento, o costume e o gênero de vida (ARIĖS, 1981, p. 195).

Para o historiador norteamericano Edward Shorter (1975), o motivo da crise da família moderna foi justamente o seu rompimento com a ordem social mais ampla. "A família tradicional era muito mais uma unidade produtiva e reprodutora do que uma unidade emocional. Era um mecanismo destinado a transmitir patrimônio e posição social de geração para geração" (p. 11). À medida que os laços exteriores e os controles sociais que mantinham a unidade familiar foram se enfraquecendo, os laços que ligavam os membros da família se fortaleceram, pautados pelo afeto e pela compreensão.

\footnotetext{
${ }^{4}$ Ariès publica “L'énfant et la vie familiale sous l'Ancien Regime" pela primeira vez em 1960, na França. A data da primeira edição brasileira é de 1978.
} 
Conforme a família passou a ser formada com base no amor romântico do casal, amor que se sustenta em bases inconscientes e irracionais, passou a haver "uma instabilidade inerente ao próprio casal [...] sendo o amor o único cimento que mantém o casal unido, a família dissolver-se-á logo que ele desapareça" (p. 12 e 13).

Outra consequencia do isolamento das famílias, para Shorter, é a perda do controle dos pais sobre os filhos: "Os adolescentes de hoje depressa se dão conta de que não são elos de uma cadeia familiar [...] Quem são e o que se tornam são coisas independentes de quem são seus pais" (p. 14). Sem os laços que prendem uma geração à outra, a autoridade moral dos pais sobre os filhos não se sustenta. Portanto, pode-se concluir que, na visão de Shorter, os mesmos sentimentos amorosos que isolaram a família dos laços sociais mais amplos e que a constituíram são os responsáveis pela sua fragilidade, como se a crise fosse intrínseca à família moderna.

Adorno e Horkheimer (1978) também se dedicaram a pensar sobre a família moderna, mas têm outro enfoque sobre a crise. Para eles não se pode pensar as relações da vida privada isoladas da dinâmica social: "A família não só depende da realidade social, em suas sucessivas concretizações históricas, mas também está socialmente mediatizada, mesmo em sua estrutura mais íntima" (p. 133). Também apontam que a família é constituída por fatores irracionais, os sentimentos. E a crise se dá justamente pelo seu antagonismo com a sociedade burguesa, pautada no sistema de troca e na racionalidade, ou seja, é contraditório estabelecer e manter laços irracionais dentro da ordem racional dominante. "Perpetuava-se um elemento irracional dentro da sociedade industrial, orientada pela ordem racionalista, pelo domínio exclusivo do princípio do 'calculismo' [...] Diante disso a família burguesa continuou, num certo sentido, sendo um anacronismo" (p. 137). Portanto, a crise não é propriamente intrínseca à família, mas à sua relação com a sociedade capitalista.

Entretanto, essa mesma família burguesa, segundo Adorno e Horkheimer, também atuava como um fator de adaptação à sociedade, pois o respeito e o amor da criança à autoridade paterna no seio da família favoreciam, posteriormente, sua submissão a qualquer outro tipo de autoridade, assim como às condições do trabalho assalariado. "A família convertera-se em agente da sociedade: era o veículo pelo qual os filhos aprendiam a adaptação social; formava os homens tal como eles tinham de ser para cumprir as tarefas impostas pelo sistema social" (p. 139). 
$\mathrm{Na}$ visão desses pensadores, a mesma dinâmica social que contribuiu para a constituição da família burguesa a ameaça constantemente, porque a capacidade técnica e a eficiência passaram a ser mais importantes do que a herança familiar para o futuro do indivíduo. A autoridade da família se enfraquece, pois já não garante de forma segura a vida material de seus membros e tampouco os protegem contra 0 mundo externo. "E a decadência histórica da família contribuiu [...] para agravar o perigo do domínio totalitário que, por sua vez, tem raízes nas mesmas tendências econômicas que vão destruindo a família" (ADORNO e HORKHEIMER, 1978, p. 144).

Se a autoridade paterna fazia com que a criança tivesse as experiências de amor e ódio dirigidas à figura paterna, o seu enfraquecimento faz com que a criança não se identifique com o pai e não interiorize as exigências impostas pela família. Assim "[...] a família cumpre cada vez menos a sua função de instituição de aprendizagem e educação [...]. Da sua relação com o pai, o filho apenas obtém uma ideia abstrata de um poder e de uma força arbitrários e incondicionados [...] e é substituído por poderes coletivos" (ADORNO E HORKHEIMER, 1978, p. 143, 144 e 145). É assim que Adorno e Horkheimer explicam, portanto, a adesão da sociedade a movimentos totalitários como o nazismo na Alemanha. Quanto mais isolados e solitários os indivíduos se sentem, mais se tornam propensos a seguir cegamente ideologias totalitárias. Portanto, para eles a própria família que contribuiu para a constituição da sociedade industrial se enfraquece na mesma proporção em que o capitalismo avança.

Christopher Lash (1991), sociólogo norteamericano, partilha do mesmo ponto de vista de Adorno e de Horkheimer ao explicar a crise da família no fim do século XIX. Segundo ele, os mesmos aspectos que fizeram com que a privacidade e a família fossem consideradas "refúgios seguros contra o mundo" também tornaram cada vez mais difícil a manutenção de seu isolamento na sociedade racional. Mas Lash aponta para outro fator importante que contribuiu para o enfraquecimento das famílias: as políticas públicas.

Os historiadores da família prestaram muito pouca atenção na forma como a política pública - às vezes concebida deliberadamente, não como uma defesa, mas sim como uma invasão da família - contribuiu para a deterioração da vida doméstica. A família não evoluiu simplesmente em resposta às influências sociais e econômicas; foi deliberadamente transformada pela intervenção de planejadores políticos (p. 35). 
Segundo Lash, os educadores e reformadores sociais passaram a considerar as famílias como um empecilho para o progresso social, uma vez que conservavam tradições, hábitos e costumes - na terminologia de Shorter, de Adorno e de Horkheimer seriam alguns dos aspectos irracionais - que atrasavam a constituição do Estado Nacional. Por isso, propuseram afastar as crianças da influência retrógada das famílias e colocá-las nas mãos bondosas do Estado, expandindo o período escolar e os serviços de bem-estar social. "Os educadores afirmavam que [...] antes a escola devia principalmente ensinar os rudimentos do conhecimento, enquanto que agora deve encarregar-se também da formação física, mental e social da criança" (LASH, 1991, p.37).

O surgimento das profissões assistenciais nas três primeiras décadas do século $X X$, para Lash, fez com que a sociedade invadisse a família, tomando para si muitas das funções desta. A nova ideologia do bem-estar social "[...] ao convencer a dona-de-casa [...] que confiasse na tecnologia e nos conselhos de especialistas externos, [...] minou a capacidade de a família prover-se a si mesma" (1991, p. 43). Assim, o próprio conhecimento transformou-se numa indústria, fazendo com que os pais se sentissem incompetentes para criar os filhos sem ajuda profissional especializada. Somente a ciência e a tecnologia modernas podiam oferecer às crianças as condições necessárias para seu amplo e integral desenvolvimento. As profissões assistenciais, aliadas à publicidade, acabaram expondo a vida pessoal ao escrutínio médico e psiquiátrico ou à manipulação da indústria da publicidade, ou seja, "o estabelecimento de uma jurisdição ética e industrial sobre o casamento frustrou assim seu próprio objetivo - reforçar o último reduto de privacidade" (LASH, 1991, p. 44). Portanto, para Lash, o enfraquecimento das famílias também está relacionado às políticas públicas do Estado do Bem-Estar Social e ao surgimento das profissões assistenciais.

Aqui no Brasil, Costa $\left(2004^{5}\right)$ relata que esse mesmo mecanismo aconteceu no nosso país no final do período colonial, principalmente nas famílias de elite. Segundo ele, a partir da terceira década no século passado, a família passou a ser considerada incapaz de proteger a vida de crianças e adultos, pelos altos índices de mortalidade infantil e das condições precárias de saúde dos adultos. Assim o pensamento médico

\footnotetext{
${ }^{5}$ A primeira edição do livro é de 1979.
} 
higienista passou a se impor à família, baseado nos preceitos sanitários da época, e revolucionou os costumes familiares.

\begin{abstract}
$\mathrm{Na}$ família conjugal moderna os pais dedicam-se às crianças com um desvelo inconcebível nos tempos coloniais. No entanto, e este é um aspecto fundamental, de maneira permanentemente insatisfatória. Perante os novos técnicos em amor familiar, os pais, via de regra, continuam sendo vistos como ignorantes, quando não doentes. Há sempre um a mais a corrigir um a menos a tratar. Amar e cuidar dos filhos tornou-se um trabalho sobre-humano, mais precisamente, científico. Na família burguesa os pais jamais estão seguros do que sentem ou fazem com suas crianças. Nunca sabem se estão agindo certo ou errado. Os especialistas estão sempre ao lado, revelando os excessos e deficiências do amor paterno e materno (p. 15).
\end{abstract}

Hobsbawm (1996) também aborda as mudanças ocorridas na família a partir de meados do século XX, corroborando alguns aspectos do pensamento de Adorno, Horkheimer e Lash. Todavia, não caracteriza essas transformações propriamente como uma "crise". Para ele, elas são reflexos de uma "revolução cultural" mais ampla que ocorreu juntamente com o avanço das sociedades industriais. A liberdade sexual que as mulheres conquistaram, o divórcio, a legalização do aborto em alguns países, etc. só se tornaram possíveis porque houve uma profunda mudança nos padrões culturais da sociedade ocidental.

Segundo Hobsbawm (1996), a primeira característica da "revolução cultural" foi a prevalência de uma cultura juvenil, em que a juventude não é mais vista como uma preparação para a vida adulta, mas como a fase do pleno desenvolvimento humano, a melhor época da vida. A segunda, decorrente da primeira, é que essa cultura juvenil tornou-se dominante nas economias de mercado (porque o poder de compra da juventude se ampliou muito) e a velocidade dos avanços tecnológicos deu aos jovens uma grande vantagem em relação aos grupos etários mais conservadores e com maior dificuldade de adaptação. "O que os filhos podiam aprender com os pais tornou-se menos óbvio" (p. 320), invertendo-se os papéis entre as gerações. E a terceira é que essa cultura nas sociedades urbanas passou a ser internacional, ou seja, "passou a existir uma cultura jovem global" (p.321).

Essa cultura juvenil, para ele, tornou-se o motor da revolução cultural que foi simultaneamente "informal e antinômica" (p. 323) principalmente em questões de 
conduta pessoal. A antinomia se tornou mais evidente quando associada à expressão intelectual em algumas manifestações lideradas pela juventude, como o levante de maio de 1968, por exemplo. Com a aparência de contestação política e de questionamento de leis repressivas, esses movimentos, na verdade, defendiam o subjetivismo, o individualismo e tornavam públicos e legítimos sentimentos e desejos privados. Deram origem a um novo liberalismo contra convenções e restrições, mas que não propunha um novo padrão de ordenação social; apenas propagava uma aceitação sem limites do desejo humano.

\footnotetext{
Assumia-se tacitamente agora que o mundo consistia em vários bilhões de seres humanos definidos pela busca de desejo individual, incluindo desejos até então proibidos ou malvistos, mas agora permitidos - não porque se houvesse tornado moralmente aceitáveis, mas porque tantos egos os tinham (HOBSBAWM, 1996, p. 327).
}

Também Shorter (1975) define a revolução sexual desse período como hedonista: "na primeira revolução sexual pré-conjugal do fim do século XVIII, a sexualidade afetiva estava ligada ao romantismo. Na segunda revolução sexual na década de 1960, estava ligada ao hedonismo" (p. 23).

Hobsbawm (1996) complementa as análises de Adorno e Horkheimer sobre as consequencias dos avanços do capitalismo porque se aprofunda nas mudanças culturais que os avanços do capitalismo nas sociedades industriais provocaram. Também conclui, como eles, que houve um "triunfo do indivíduo sobre a sociedade" (p. 328), que levou a um rompimento dos laços e mecanismos sociais que ligavam os seres humanos em "texturas sociais" (p. 328). Isso enfraqueceu a família e a comunidade, fortalecendo uma sociedade anônima e impessoal. E, com a participação das políticas públicas, como assinala Lash, a sociedade transferiu algumas das responsabilidades tradicionais das famílias, como o cuidado com os velhos e as crianças, para o Estado, o chamado "Estado do Bem-Estar Social" (p. 332), rompendo com velhos valores e costumes.

Assim como Adorno e Horkheimer, Hobsbawm afirma que a família colaborou para a consolidação do capitalismo porque oferecia uma educação moral pautada em hábitos de trabalho, obediência, confiança, lealdade, além de ensinar a ter 
disposição para adiar a satisfação imediata. E o capitalismo, apesar de construído nas operações de mercado, dependia dessas motivações "[...] o capitalismo venceu porque não era apenas capitalista" (HOBSBAWM, 1996, p. 336) Com o enfraquecimento desses valores, "o capitalismo podia funcionar sem isso, mas, quando o fez, tornou-se estranho e problemático mesmo para os homens de negócios". (p. 335) É esse individualismo, portanto, um dos ingredientes fundamentais da crise nas famílias, segundo Hobsbawm.

Mais um pensador, agora um filósofo e educador brasileiro, que já trabalhou em escolas particulares renomadas da cidade de São Paulo como orientador pedagógico e diretor, será apresentado não só por complementar algumas das ideias dos importantes autores já citados, mas porque suas reflexões partem de sua experiência profissional com a elite da sociedade paulistana. É possível, assim, relacionar esses fenômenos globais, como o enfraquecimento das famílias em função do avanço do capitalismo, com uma das realidades brasileiras. Enquanto os pensadores até agora mencionados fizeram análises estruturais e históricas sobre a questão da crise nas famílias, Dante Donatelli (2004) esmiúça os efeitos dessa crise e desses novos valores no interior da família, aprofundando-se na questão das transformações do papel da mulher e na invasão do espaço público pela esfera privada.

Segundo Donatelli (2004), não houve, a partir de meados do século XX, uma reorganização estrutural da família, mas apenas mudanças nos valores, nas funções, nas regras estabelecidas internamente e na sua ligação com a esfera pública, principalmente em função da industrialização e da transformação do papel feminino. Se, antes, o papel da mulher estava restrito a casa, ela passa agora a assumir o espaço público com a sua entrada definitiva no mercado de trabalho. "Não porque os homens se tornaram tolerantes com as mulheres, mas porque não existia alternativa para eles: havia uma pressão econômica e antropológica oriunda do exterior, vinda de fora da segurança do lar" (p. 45).

A possibilidade de escolher o parceiro e o sentimento de igualdade diante do homem, corroborados pelo mesmo nível de escolaridade, a profissionalização e a experiência de corresponsabilidade financeira e moral da família, aponta Donatelli, "permitiram às mulheres reinventar o público e o privado" (p. 59). Na prática, o que 
passou a acontecer na vida de um casal foi o retardamento da vinda dos filhos, a diminuição do número destes e o divórcio como uma saída possível quando se deixa de ter projetos e perspectivas comuns ou quando se constata a dificuldade de viabilizar o amor romântico. Obviamente, numa sociedade hedonista e individualista tal como a caracterizada por Hobsbawm, é bem mais difícil conciliar desejos individuais com projetos comuns. E, como diz Shorter (1975) "o afeto e o amor romântico [...] se assentam na imprevisibilidade e na transitoriedade. Está-se profundamente ligado a uma pessoa num dia, no outro já não" (p. 13).

Donatelli, apoiado em Ariès, lembra que o fenômeno do amor incondicional e devotado dos pais pelos filhos é relativamente recente. E esse sentimento, muitas vezes, é associado, nos pais contemporâneos da elite, a uma culpa desmedida por não poderem estar presentes o tempo todo na vida cotidiana dos filhos, acompanhando o seu crescimento e o seu desenvolvimento. Dessa forma, há uma mistura desses dois sentimentos - amor e culpa - que é extremamente perniciosa para o desenvolvimento dessas crianças. Elas se tornam mimadas, superprotegidas e dependentes. E os pais "[...] sentindo-se culpados por tudo o que deu errado e, principalmente, por aquilo que possa vir a dar, compensam a situação consumindo grande parte do que a indústria cultural e de quinquilharias produz" (p. 69).

Enfim, Donatelli também constata que a chamada família moderna nuclear está em crise. Segundo ele, estamos vivendo um momento de transição, sem a construção de um modelo ideal de família.

\begin{abstract}
A ausência de papéis definidos entre homens e mulheres permite que o vazio moral seja um adjunto na confusão vivida dentro de casa. Uma existência voltada para o acúmulo material, antes de ser uma vida para a construção de um legado, torna-se um dever enfadonho de juntar coisas, e não de agregar sujeitos (p. 79).
\end{abstract}

Na sua análise, Donatelli, assim como Adorno e Horkheimer, traz o problema do enfraquecimento da autoridade nas famílias. Os dois pensadores, como já foi exposto, afirmam que sem a autoridade familiar, principalmente a paterna, os filhos não se identificam totalmente com os pais e não interiorizam exigências repressivas fundamentais para a formação do indivíduo autônomo. Já para Donatelli, o 
enfraquecimento da autoridade familiar faz com que a afetividade substitua as relações de mando. "A coação e a força da autoridade [...] hoje se esvai em afetividade. E somente em afetividade" (p. 30), tornando os pais reféns do próprio afeto pelos filhos e incapazes de lhes ensinar como se comportar na vida pública.

Há, segundo Donatelli, hoje em dia, uma confusão entre público e privado. A distinção clássica de que o privado é o espaço da família e do afeto e de que o público é o lugar do trabalho e da cidadania, o que exige dos indivíduos o cumprimento de regras morais, não é mais tão simples. "Paulatinamente, o público foi perdendo terreno para a esfera privada [...]" (p. 26). O que era a marca da vida privada, a afetividade, foi invadindo o público, passando a regular suas relações e descaracterizando-o como o seu oposto. "Em um verdadeiro exercício de tirania sobre a vida pública, a vida privada se apropriou dos valores que regulavam a vida política" (p. 31).

Por outro lado, a vida privada passou a se reduzir à intimidade, "e somos íntimos de alguém à medida que podemos fazê-lo cúmplice, sem que necessariamente haja amor para balizar essa cumplicidade" (p. 37). Inspirado em Lash, Donatelli afirma que o privado desaparece, o íntimo assume o seu lugar e, sem a fronteira públicoprivado, a intimidade se expõe ao "escrutínio" da mídia e das profissões técnicas e especializadas, como psicólogos, psiquiatras, e até mesmo da escola. Não é mais possível se refugiar na casa e na família. Portanto, para Donatelli, a crise da família está vinculada à indistinção entre o espaço público e o privado, sendo que a perda dessa noção obedece à própria lógica do mundo capitalista burguês.

A partir da exposição das ideias de todos esses pensadores, pode-se concluir que a crise nas famílias é decorrente de dois fatores importantes: o seu rompimento com a comunidade, em função da escolha amorosa dos parceiros, como traz Shorter e Ariès, e a contradição em estabelecer e manter laços irracionais dentro da ordem racional dominante - ordem que dependeu do afeto e da família para se constituir, mas que depois a invadiu e a subverteu -, na explicação de Adorno e Horkheimer. Mas é, além disso, alimentada pelas políticas públicas do Estado do Bem-Estar Social e pela expansão dos serviços assistenciais, na visão de Lash, reforçada pela cultura individualista e hedonista, caracterizada por Hobsbawm, pela inserção definitiva da mulher no mercado de trabalho e pela indistinção entre o espaço 
público e o privado, como diz Donatelli. E, apesar das razões quase estruturais do enfraquecimento das famílias e de tantos fatores agindo sobre elas desde a constituição das sociedades capitalistas industriais, é de se espantar que ainda existam...

\subsection{A família vai bem, obrigado.}

O filósofo contemporâneo francês Luc Ferry (2008), que foi ministro da educação na França entre os anos de 2002 a 2004, traz uma nova perspectiva sobre as famílias. Leitor de uma grande parte dos autores mencionados no item anterior, para ele é justamente a partir da vida privada que valores como igualdade, liberdade e fraternidade podem ser reconstruídos socialmente. Para Ferry, o viver em família não significa uma recusa e um desinteresse pelo mundo público e coletivo, mas a possibilidade de se pôr em prática um novo humanismo e uma democracia autêntica. Ferry (2008) chega a ser bastante contundente com os que alardeiam que a família está enfraquecida e em perigo por causa de suas novas configurações. "Sejamos claros: esse clichê está histórica e filosoficamente errado" (p. 77).

Segundo ele, "o século XX funcionou como um ácido" (p. 13), pois se voltou a desconstruir tradições e a elevar o potencial individualista, o que por si só suscita medo e angústia. Por outro lado, o capitalismo globalizado reavivou o mito da criatura que escapa ao domínio do seu criador. A lógica dominante dos mercados financeiros faz com que a sociedade tenha a impressão de que os dirigentes políticos têm cada vez menos controle sobre o mundo, que o "Estado é fraco" ( $p$. 17), o que gera descrença e paralisia. E é neste contexto social que Ferry acrescenta que o crescimento dos valores da intimidade não deve ser considerado um "recolhimento individualista", mas o caminho para um humanismo maduro. É na família "[...] que subsistem e até se aprofundaram formas de solidariedade das quais o restante da sociedade, dominado quase que exclusivamente pelos imperativos da competição e da concorrência, quase não tem mais conhecimento" (p. 74 e 75).

Ao traçar uma perspectiva histórica da família, Ferry entende sob outra ótica o casamento por amor, o amor parental e a privacidade, as três grandes rupturas da família tradicional para a família moderna. Enquanto antes o bom casamento era o 
que assegurava a conservação e a transmissão do patrimônio, hoje o casamento por interesse é desprezado e é valorizado somente aquele em que o amor é compartilhado. No seu ponto de vista, é justamente a escolha livre e a afinidade entre os parceiros que permitem que a família tenha funções afetivas e educativas, pois o afeto entre os pais é uma das condições para o amor parental. Quanto à privacidade, considera-a como uma proteção da vida familiar à influência, muitas vezes agressiva e repressora, da comunidade.

Essas novas concepções, na visão de Ferry, fizeram com que "o sentido da vida se viu virado de cima para baixo, pois a partir dali seria o amor profano - e não mais o amor a Deus - a dar à existência dos indivíduos a sua significação mais manifesta" (p. 91 e 92). Os valores transcendentes não desapareceram com a desconstrução dos valores do século XX, nem com a globalização, mas se voltaram para a própria humanidade. A própria noção de sacrifício, inseparável da noção de sagrado, definida como a disposição do indivíduo em dar a própria vida por algo superior a ele mesmo, se volta para o humano. Qualquer pai ou mãe hoje em dia é capaz de arriscar a vida para salvar ou proteger quem amam. Mas esse sentimento de "transcendência" e solidariedade não está presente apenas na família. Ferry lembra o exemplo da organização "Médicos Sem Fronteiras", formada por pessoas dispostas a arriscar a vida pela de outras. E é essa a base para o que define como "humanismo pós-metafísico".

\footnotetext{
O humanismo pós-nietzschiano que proponho se baseia na constatação de uma exterioridade ou uma transcendência radical de valores, mas justamente afirmando que se manifestam exclusivamente na imanência da consciência. Eu não invento a verdade, a justiça, a beleza ou o amor, eu os descubro em mim mesmo, mas como algo que me ultrapassa e que, por assim dizer, me é dado a partir de fora - sem que eu possa identificar 0 fundamento último dessa doação (p. 98 e 99).
}

Ao contrário de Hobsbawm e de Donatelli, Ferry (2008) não pensa que o sagrado na vida privada provoca a atomização do social ou a "emergência do indivíduo rei", pois nem o indivíduo se opõe ao coletivo e nem a vida privada, à vida pública. Afinal, questões coletivas se expressam no indivíduo. Nas existências particulares se encontram, muitas vezes, as mesmas dificuldades, como a capacidade de consumo, 
a vida escolar dos filhos, separações, doenças, acidentes, etc. E é por isso que na sua visão a política deve se voltar para as famílias, a vida pública deve se intrometer na vida privada, garantindo, por exemplo, educação e saúde para todos igualmente. "Não que as ideias de pátria e de república me pareçam absurdas e fora de moda [...] Só que elas mudaram de sentido [...] não mais as pessoas devem servi-las [...] agora estas entidades [...] que estão sendo e devem ser mais ainda postas a serviço dos seres humanos" (p. 109 e 110).

Portanto, para Ferry a família não só não está em crise como é o laço social que mais se intensificou nos últimos dois séculos, podendo se tornar a base para uma nova forma de pensar e fazer política. "Frequentemente decomposta, situada fora do casamento ou sem dúvida recomposta, no entanto menos hipócrita, mais autêntica e mais atraente do que nunca na história: é este o paradoxo da família moderna" ( $p$. 74).

Sua visão é coincidente com aquela que a psicanalista francesa, Elizabeth Roudinesco, expressa em sua obra A família em desordem, de 2003. Nesse livro ela busca entender por que homossexuais, homens e mulheres expressam desejo de formar uma família por meio do casamento, da adoção ou da procriação medicamente assistida. A questão que fica ainda mais intrigante se considerarmos que a homossexualidade "sempre foi repelida da instituição do casamento e da filiação" (p. 7) e que intelectuais homossexuais, como Oscar Wilde, Arthur Rimbaud e Marcel Proust, por exemplo, contestavam bravamente e rejeitavam a família justamente por ela oprimir o desejo e a liberdade sexual. Depois de uma leitura psicanalítica da história da família moderna, Elizabeth Roudinesco conclui: "a família contemporânea, horizontal e em redes vem se comportando bem e garantindo corretamente a reprodução das gerações" (p. 197).

Ainda acrescenta que o casamento se desfez de sua antiga sacralidade e se tornou um modo de conjugalidade afetiva, em que as pessoas podem se proteger das desordens do mundo exterior. Os filhos acabam assistindo às núpcias dos pais, que se unem não para uma vida inteira, mas provavelmente para viverem momentos felizes até se culminar no divórcio ${ }^{6}$. E, mesmo que os avanços tecnológicos venham

\footnotetext{
${ }^{6} \mathrm{Na}$ França um em cada três casamentos termina em divórcio, segundo os dados trazidos por Roudinesco.
} 
possibilitar a reprodução sem o ato carnal, "o desejo de um filho sempre terá algo a ver com a diferença dos sexos" (p. 198). Para a autora, portanto, as novas configurações da família não são indícios de que ela está se desfazendo, mas, pelo contrário, são provas de que está sendo reinventada, pois é desejada por homens, mulheres e crianças de todas as idades e de todas as orientações sexuais. É "reivindicada como único valor seguro ao qual ninguém quer renunciar [...] e parece em condições de se tornar um lugar de resistência à tribalização orgânica da sociedade globalizada" (p. 198 e 199).

\subsection{Conflitos e incertezas na relação família-escola}

Independente de as novas configurações familiares serem indícios ou não da dissolução da família, como a escola, outra instituição responsável pela educação de crianças e jovens, reage diante dessas mudanças? Como essas transformações culturais e morais se refletem na escola e no trabalho do professor? Há uma sensação entre os educadores, reforçada pelo pensamento de alguns intelectuais, de que essa "nova" família parece não ser capaz de cumprir algumas funções educacionais que são a base para a educação escolar e delega essa tarefa para a escola. Adorno e Horkheimer, por exemplo, afirmam que "a família cumpre cada vez menos a sua função de instituição de aprendizagem e de educação" (1978, p. 143).

Também Hanna Arendt (1997 ${ }^{7}$ ) aponta para uma "crise na educação", tanto na escola como na família. Para ela, como a essência da atividade educacional é a conservação do saber sistematizado pela humanidade, e o problema da educação na era moderna é que ela não pode abrir mão da autoridade e da tradição num contexto cultural e social que já não é mais estruturado por autoridade e tradição. Além disso, na escola alguns pressupostos pedagógicos, como a concepção de que as crianças devam aprender mais entre elas do que com os adultos; a transformação do ato de ensinar em ciência do ensino - o surgimento da pedagogia - e a concepção de que para aprender é preciso fazer ou entender a aplicação do conhecimento, colaboraram ainda mais para confundir a tarefa da escola e do professor.

\footnotetext{
${ }^{7}$ O texto em que Hanna Arendt trata da crise na educação foi publicado pela primeira vez em 1954.
} 
As ideias desses pensadores parecem ser confirmadas por pesquisadores contemporâneos. Oliveira (2002), nas conclusões da sua pesquisa sobre as representações de pais e professores de seus papéis, escreve que a escola tutela a família - principalmente sua dinâmica afetiva -, que, por sua vez, abre mão do direito de resolver seus problemas interiores, tal como Lash (1991) descreve. Assim, criam-se, em vez de espaços de troca e de interação, demarcações insólitas que geram tensões e indicam que nem família e nem escola sabem mais quais são os seus papéis e o que as diferenciam. "A desconfiança e a vigilância quase concretas da escola em relação à família e desta em relação àquela parecem apontar para um contrato mal-escrito entre essas duas agências, que precisam se auto-aderir para se sustentar. Pais tentam vigiar a escola, e professores tentam entrar nos lares" (OLIVEIRA, 2002, p. 138 e 139).

E Silveira (2003) também afirma que as famílias, antes, tinham formas mais claras de educar os filhos, pautadas na autoridade e na hierarquia. "No entanto, com o surgimento de muitas ideias psicológicas e de um movimento pedagógico e psicológico em prol da autonomia das crianças [...] os pais parecem ter perdidos seus referenciais" (p. 129). Além disso, uma participação maior da mulher na sociedade fez com que os cuidados com os filhos ficassem terceirizados e o contato entre pais e filhos mais restrito. Assim, os pais "buscam desfrutar com os filhos momentos de prazer, sem sancioná-los, frustrá-los ou provocar qualquer forma de conflito. Fica implícito, então, nessa prática, que tal tarefa cabe à escola" (p. 130).

Fraiman (1997) também corrobora a ideia de que os pais delegam cada vez mais tarefas para a escola e de que esta acaba aceitando ampliar seus papéis. Em sua pesquisa, ele trouxe também a opinião de alguns educadores de escolas particulares de São Paulo, dada para a jornalista Fernanda Scalzo do jornal "Folha de São Paulo", publicada em 26 de março de 1995 e nomeada "Má educação vem de casa, dizem as escolas". A diretora de uma renomada escola particular de São Paulo revela: "[...] a maioria das escolas acaba reconhecendo que um dos papéis que tem que fazer é o da reeducação dos pais. A gente aqui tem reunião de pais para discutir questões de cidadania" (SCALZO, 1995, citado por FRAIMAN, 1997). Um diretor de outra escola particular também afirma "[...] a família delega: que a escola eduque" (SCALZO, 1995, citado por FRAIMAN,1997). 
Entretanto, para Donatelli (2004) a escola também colabora para essa confusão de papéis, porque não olha para fora de si mesma para buscar compreender as transformações sociais e culturais à sua volta e confunde sua função política de preparar as novas gerações para a cidadania, ou seja, para a vida pública, com a substituição da condição familiar. Está esvaziada de princípios e se deixou invadir por inúmeras teorias psicológicas discutíveis, que tudo explicam e justificam do ponto de vista individual, desconsiderando as necessidades da coletividade.

\footnotetext{
Como se estivesse acuado, o adulto, na família e na escola, parece se render a um plano de concessão e oferecimento desmesurado. Passamos da autoridade paterna autoritária e intransigente - que formava pela coerção - para a liberalização pura e simples, mediatizada na vida privada pelo consumo, materialização da incapacidade discursiva e conflituosa. E na esfera pública da escola, para o psicologismo barato que tudo compreende, tudo concede no íntimo de cada um, desconsiderando as necessidades do todo em relação à parte, reforçando individualismos deformadores (p. 127).
}

Portanto, na visão desses pensadores e pesquisadores, não só a família está em crise, mas a escola também. E como pode se dar a relação entre duas instituições em crise? Problemática, conflituosa e cheia de acusações mútuas. "Ao que se refere à escola [...] que tem por dever a socialização da criança - parece entrar em uma guerra surda com as famílias no momento de expor as crianças a um plano de regramentos e valores [...] (DONATELLI, 2004, p. 18). O próprio Ferry (2008), que é bastante otimista em relação às novas configurações familiares, diz: "não gosto daquilo em que alguns estabelecimentos escolares se tornaram no pós-1968, mas permitam-me dizer que detestava ainda mais o que eram antes" (p. 109).

Enguita (2004), entretanto, caracteriza as transformações sociais que afetaram a família e a escola de maneira menos dramática. Aponta que a crise da família é, em parte, uma crise das instituições socializadoras - como a comunidade e a igreja que desapareceram, retraíram-se ou simplesmente perderam a eficácia. As mudanças advindas da vida moderna trazem desvantagens, mas também vantagens. "Para o bem e para o mal, essa forma tradicional se foi para não voltar" (p. 63). Se a vida moderna trouxe a ausência de regras, o risco e a violência, além de transformar a rua num lugar temido, por outro lado ela também trouxe mais 
liberdade pessoal, maior diversidade social e mais riqueza cultural, fez desaparecer o controle das pequenas comunidades sobre os indivíduos e proporcionou a emancipação definitiva da mulher.

\begin{abstract}
Ainda que sejam frequentes entre os professores as críticas à 'transferência' de responsabilidades por parte da família (querem ficar livres das crianças o maior tempo possível; veem na escola uma creche ou um albergue; etc.), não há nada de surpreendente nesse processo. Trata-se, em que pese a redundância, de uma socialização da custódia análoga à de qualquer outra atividade para a cobertura de nossas necessidades (p. 64).
\end{abstract}

Na visão de Enguita (2004), hoje a escola faz o papel de complementar a família como antes a pequena comunidade fazia. Se antes a escola tinha um papel discreto na vida das pessoas (durava 4 a 6 anos, para a maioria), agora passou a ocupar toda a infância, a adolescência e parte da juventude. E mais tempo na escola é menos tempo na família, ou seja, a própria escola "varreu todas as instituições extrafamiliares [...] e foi acuando a própria família" (p. 67). Quanto à ideia recorrente, de que o papel da escola deve estar restrito ao ensino da herança cultural, Enguita é bem claro: "a principal função da escola nunca foi ensinar, mas sim educar" (p. 68), e os próprios professores sempre reivindicaram seu papel de educadores. Assim, em vez de se lamentar, a escola deve compreender que ela e a família "ficaram sozinhas nessa tarefa e que nenhuma outra instituição virá, nem pode vir socorrêlas" (p. 70). Agora, portanto, cabe a elas buscarem novas formas de dividir essas funções de maneira que seja possível conciliar custódia e ensino.

\title{
1.5. Quando a escola também não cumpre o seu papel: a forte tendência de responsabilizar as famílias.
}

Esse complexo e contraditório contexto social descrito acima que, se não causa a crise na família e na escola, pelo menos favorece que ambas se estranhem e se desconheçam é muito favorável para o estabelecimento de preconceitos e explicações simplistas para eventuais problemas que venham a surgir dessa relação. Se muitas famílias demonstram que não são capazes de ensinar, com afeto, as crianças a respeitarem a autoridade e abrirem mão de suas vontades 
imediatas, a escola, por sua vez, também se mostra muitas vezes incapaz de ensinar o saber sistematizado da humanidade igualmente a todos que a frequentam. Nas palavras de Patto, "trata-se de uma incapacidade crônica da escola de garantir o direito à educação escolar a todas as crianças e jovens brasileiros, independente de cor, de sexo e de classe social" (1997, p. 281).

A escola e seus educadores se sentem sobrecarregados por terem de assumir funções que consideram não ser genuinamente suas, e as famílias também se queixam de que seus filhos não aprendem tudo o que deveriam e poderiam nas escolas. Aliás, não são apenas as famílias que se queixam desse problema; a sociedade como um todo parece se preocupar com ele. Aqui no Brasil, pelo menos, depois que o acesso à educação se democratizou - segundo dados do governo federal, na faixa de 6 a 14 anos, 97\% da população está na escola (AUMENTA MATRÍCULA NA EDUCAÇÃO INFANTIL, HTTP://portal.mec.gov.br/index.php) -, o grande desafio das políticas públicas educacionais tem sido evitar a evasão escolar e melhorar a qualidade de ensino nas escolas. Aqui em São Paulo, por exemplo, foram implantadas a promoção automática nas séries iniciais (há mais de 15 anos) e uma série de exames avaliatório para verificar o nível de aprendizado dos alunos, principalmente em Português e Matemática. Atualmente, a tentativa é de aumentar os recursos para cada unidade escolar, de acordo com a evolução dos resultados dos alunos nos exames ${ }^{8}$.

Numa reportagem recente da Revista Veja (24 de dezembro de 2008), intitulada "Um plano para avançar", a jornalista Camila Pereira escreveu que as deficiências das escolas brasileiras já foram diagnosticadas e que agora o país tem metas e prazos para superá-las. Um grupo de especialistas ligados à ONG "Todos pela Educação" estabeleceu metas para a melhoria do ensino em todos os níveis e deu prazo para que fossem cumpridas ano a ano, e o próprio Ministério da Educação (MEC) já se comprometeu a buscar os mesmos objetivos. "Segundo o levantamento da ONG apenas $10 \%$ dos estudantes brasileiros se formam tendo assimilado

\footnotetext{
${ }^{8}$ Este problema, embora muito crítico no Brasil, parece que também está presente em vários países do mundo, inclusive em países da Europa. Enguita, por exemplo, diz a respeito da realidade espanhola "Quando a escolarização era apenas nominalmente universal, a desescolarização de fato e o absenteísmo eram a válvula de escape que livrava a escola da pressão interna de grupos mais resistentes. Quando a universalidade se tornou efetiva, problemas que antes estavam fora das salas de aula passaram a estar dentro." (ENGUITA, 2004, p. 70)
} 
conceitos básicos de matemática e mais da metade dos jovens não consegue concluir o ensino médio na idade adequada" (p.114 e 115).

Diante desse quadro, em vez de a escola e de seus educadores buscarem investigar primeiro dentro dela as causas para as dificuldades de aprendizagem de seus alunos, tendem a responsabilizar exclusivamente de suas famílias. Pelo menos é o que apontam diversos pesquisadores: Carvalho (2000); Marques (2002); Szymanski (2003); Polonia e Dessen (2005); Gasonato (2007). Szymanski, por exemplo, diz:

\footnotetext{
É frequente ouvirmos depoimentos de professoras ou membros da equipe escolar acerca de que as famílias são 'desestruturadas', desinteressadas, carentes e, no caso, de comunidades de baixa renda, violentas. Tais condições constituem-se numa explicação 'fácil' para o insucesso de algumas crianças. [...] Tal raciocínio preconceituoso só serve para atribuição de culpa a uma situação externa à escola e para um conseqüente afastamento do problema (2003, p. 68).
}

Marques (2002), estudioso português, por meio de uma pesquisa sobre a relação família-escola, realizada em vários países, constata:

Os professores esperam que haja continuidade de valores e atitudes entre a escola e o lar e quando isso não acontece tendem a culpar as famílias, acusando-as de falta de interesse na educação dos filhos e falta de cultura. [...] Notou-se um uso persistente e continuado, em todas as escolas, de formas de comunicação negativas, que deitam as culpas aos pais pelo fracasso dos filhos e que acentuam os problemas escolares (p. 3).

Sá (2001), outro pesquisador português, afirma que o sentido atribuído à participação dos pais pelos educadores se reduz à colaboração ao que eles próprios propõem. Por isso, interpretam com uma "monorracionalidade" a não-participação deles nas atividades escolares, ou seja, consideram-na sempre como falta de interesse pelos filhos e pela sua escolaridade, quando Sá, na sua pesquisa, identificou vários motivos para a não-participação ocorrer. Há pais, inclusive, que acham que não devem interferir em assuntos da escola: não participam porque julgam que está tudo bem. Lahire (2004) afirma que a omissão parental é um mito e 
que na sua pesquisa quase todos os participantes demonstraram o sentimento de que a escola é importante e esperam que seus filhos se saiam melhor do que eles:

\begin{abstract}
Esse mito é produzido pelos professores, que, ignorando as lógicas das configurações familiares, deduzem, a partir dos comportamentos e dos desempenhos escolares dos alunos, que os pais não se incomodam com os filhos, deixando-os fazer as coisas sem intervir. Nosso estudo revela claramente a profunda injustiça interpretativa que se comete quando se evoca uma 'omissão' ou uma 'negligência' dos pais (p. 334).
\end{abstract}

Vários estudiosos também afirmam que é comum encontrar no discurso de educadores a expectativa de que seus alunos fossem oriundos de uma família nuclear tradicional, uma "família estruturada", em que o pai é o principal responsável pela sustentação financeira e a mãe dedica-se com afinco ao acompanhamento das tarefas escolares, já que não trabalha fora ou trabalha apenas por meio período (CARVALHO, 2000; SOUZA, 1997; PATTO, 1997). Os professores e educadores, alienados de todas as transformações sociais que acabaram por interferir na organização das famílias, quando se deparam com dificuldades de aprendizagem ou de disciplina de seus alunos, atribuem às famílias a causa do problema, uma explicação simplista que os exime de qualquer responsabilidade.

Por mais que pais ausentes e desinteressados possam gerar indiferença e afastamento de crianças e jovens do aprendizado escolar, há, muitas vezes, por parte da escola, uma generalização indevida dessa explicação. Muitos pesquisadores têm denunciado o caráter ideológico e preconceituoso dessa visão. As dificuldades de aprendizagem e o fracasso escolar são produtos de múltiplos fatores, incluindo o funcionamento da própria instituição escolar. Patto (1997), por exemplo, aponta para ações e reações de educadores pautadas no preconceito e na discriminação dentro da própria instituição escolar e denuncia também as pesquisas educacionais e suas conclusões ideológicas mascaradas por conhecimento científico, como é o caso da "teoria do déficit cultural", que só colabora para o fortalecimento desses preconceitos. E Perrenoud (2001) também afirma que o fracasso escolar pode ser produzido pela própria escola; afinal, ela estabelece um currículo ao qual os alunos têm de se adaptar, mas que apenas alguns são capazes de seguir à risca. 


\subsection{Família e Escola: Parceria e corresponsabilidade.}

Em face dessa realidade, alguns estudos (MARQUES, 2002; SZYMANSKI, 2003; POLONIA; DESSEN, 2005; GASONATO, 2007) desenvolvidos enfatizam a necessidade de a escola se aproximar das famílias de seus alunos, buscando realizar um trabalho em parceria com elas. Essa aproximação pode permitir a quebra de preconceitos por parte da escola em relação às famílias e uma compreensão maior, por parte da família, do papel da escola e da sua forma de trabalhar. Não se trata de ensinar à família como se educa, mas de criar "[...] um espaço onde pais e educadores possam pensar e construir um contexto significativo que lhes permita ir compartilhando algumas decisões ao mesmo tempo" (SILVEIRA, 2003, p.130).

Quando há essa aproximação, mostram os resultados de pesquisas (MARQUES, 2002; POLONIA; DESSEN, 2005), as consequencias são bastante satisfatórias. Os pais sentem-se valorizados e tornam-se aliados dos professores que, por sua vez, passam a desenvolver formas de acompanhamento e auxílio sistemático aos alunos, permitindo que eles desenvolvam mais o seu potencial. Para Paro (2000), mesmo que a escola tenha como desafio que o próprio aluno queira aprender, "precisa ter presente a continuidade entre educação familiar e a escolar, buscando formas de conseguir a adesão da família para sua tarefa de desenvolver nos educandos atitudes positivas e duradouras com relação ao aprender e ao estudar" (p. 16).

Além disso, acrescenta Caetano (2003), essa iniciativa de aproximação deve partir da escola e de seus educadores. Segundo Paro (2000) é por meio de uma postura positiva da instituição em relação aos seus usuários, oferecendo situações de diálogo e de convivência, que se proporcionará uma participação efetiva deles na vida escolar de seus filhos. Há pesquisas, no entanto, que revelam que as escolas, mesmo assumindo o discurso da importância da participação das famílias, adotam uma posição de assimetria (GASONATO, 2007; RIBEIRO, 2006; GARCIA, 2005; CAETANO, 2003) em relação a elas, pois exigem a sua presença apenas para corroborar seus próprios encaminhamentos (GOMES, 2007) ou demonstram falta de iniciativa e omissão de orientação nos espaços reservados para isso, como as reuniões de pais (PARO, 2000). Há poucos casos em que família e escola compartilham responsabilidades (GOMES, 2007). 
Este projeto de pesquisa busca dar continuidade à reflexão sobre a relação famíliaescola realizada até o momento e reforçar a importância de se estabelecer uma parceria produtiva entre essas duas instituições. Se, por um lado, a família, em suas novas configurações, não pode ser considerada como a única responsável pelo insucesso escolar de seus filhos, por outro lado é possível acreditar que sua aproximação com a escola só venha beneficiar e potencializar a aprendizagem acadêmica da criança. Polonia e Dessen (2005) no final do seu artigo, endossam essa crença, afirmando que:

Faz-se mister, sobretudo, estimular as produções acadêmicas direcionadas ao estudo do envolvimento da família com a escola, transformando-as em fomento e em mecanismos que contribuam para $o$ planejamento de políticas e de programas educacionais (p. 310).

As bases dessa parceria produtiva devem considerar, por um lado, a família como um fenômeno social e historicamente situado, ou seja, afastar a concepção acrítica de que "basta tornar-se pai ou mãe para saber educar crianças e adolescentes" (SZYMANSKI, 2000, p.22), e, por outro, de que a responsabilidade da educação de crianças e jovens na nossa sociedade industrial, com pais e mães inseridos na tarefa da sustentação financeira, é da família e da escola igualmente. Seus papéis são paralelos, simétricos e, portanto, devem ser pautados (usando ideias e terminologias piagetianas) pela cooperação e pelo respeito mútuo, e não pela primazia de uma sobre a outra (CAETANO, 2003).

\footnotetext{
Não só os pais contam com a escola, mas esta, igualmente, conta com eles. Por isso a instituição escolar precisa conversar com eles, dar orientações, promover palestras, saber o que está acontecendo com a criança em casa, como ela está vivendo ou reagindo a muitos e inevitáveis problemas existentes em qualquer família (doença, separação, mudança de emprego, modos de organização da casa, problemas financeiros, relacionamento entre o casal, nascimento de outros filhos). A escola também precisa compartilhar com os pais aspectos da conduta de seu filho na escola (relacionamento com colegas, aproveitamento escolar, atitudes, valores, respeito às normas, qualidade na realização das tarefas). Por isso, a interdependência, ou seja, o esforço comum e recíproco para promover o desenvolvimento da criança (MACEDO, 2005, p. 12).
} 
É o próprio Piaget que diz:

Uma ligação estreita e continuada entre os professores e os pais leva, pois, a muita coisa mais que uma informação mútua: este intercâmbio acaba resultando em ajuda recíproca e, frequentemente, em aperfeiçoamento real dos métodos. Ao aproximar a escola da vida ou das preocupações profissionais dos pais e ao proporcionar, reciprocamente, aos pais um interesse pelas coisas da escola, chega-se até mesmo a uma divisão de responsabilidades [...] $\left(1991^{9}\right.$, p. 50).

Numa realidade escolar como a brasileira, marcada por inúmeras deficiências, divulgadas amplamente para toda a sociedade pela mídia quase cotidianamente, comprometer - e não responsabilizar - as famílias com o acompanhamento escolar de seu filhos pode revelar-se como mais uma das possibilidades para a melhoria da qualidade de ensino. Os caminhos prováveis para que esse comprometimento ocorra são o principal interesse deste trabalho.

\subsection{Objetivos}

1) Avaliar, por meio de entrevistas semiestruturadas, como pais, cujos filhos frequentam escolas particulares, concebem seus papéis no tocante à educação escolar desses filhos e como agem no acompanhamento dos seus estudos.

Essa avaliação terá como foco as seguintes questões: Quais os critérios para escolher a escola? O que pensam os pais dela? Acompanham o estudo dos filhos? De que maneira? Conferem a lição de casa? Exigem boas notas dos filhos? Participam das reuniões de pais e de eventos promovidos pela escola? Como avaliam as reuniões e as outras atividades da escola? Interferem na organização curricular da escola de alguma maneira?

2) Conhecer as expectativas dos pais em relação ao papel da escola na formação dos alunos.

\footnotetext{
${ }^{9}$ A primeira edição deste livro é de 1972.
} 
Procurar inferir se os pais confiam ou não no ensino da escola. Se confiam, mas têm críticas, quais são e de que natureza são essas críticas; em que medida percebem abertura da escola para estabelecer parcerias em questões relacionadas ao desenvolvimento dos filhos ou mesmo para o aperfeiçoamento de ensino e do currículo.

3) Relacionar o ponto de vista dos pais com algumas ideias de pensadores e pesquisadores sobre a família e sobre a relação família-escola, procurando verificar se reconhecem ou não o cenário de crise de valores e de autoridade, caracterizado por autores como Adorno e Horkheimer e Donatelli, e se, de fato, esperam que a escola se responsabilize por aspectos da educação de seus filhos pois não se sentem capazes de cuidar e/ou não pensam ser de sua responsabilidade.

4) Propor, a partir dos autores estudados e da análise dos dados, algumas sugestões para a atuação das escolas juntos às famílias, de forma a tornar a integração entre essas duas instituições mais efetiva, sempre considerando as especificidades da realidade estudada.

Embora muitos estudos tenham revelado que a parceria entre família-escola é muito importante para um bom desempenho de crianças e jovens na escola, poucos são os trabalhos que indicam como essa parceria deve ser estabelecida. 


\section{CAPÍTULO 2}

\section{MÉTODO:}

\subsection{Constituição da amostra}

\subsubsection{Seleção dos participantes:}

A seleção dos pais participantes foi feita por meio de contato telefônico com a direção das escolas. Os diretores das duas primeiras solicitaram uma reunião pessoal para maiores esclarecimentos, mas o da terceira não achou necessário e todas as explicações foram dadas por telefone ou por correio eletrônico. Justamente nesse contato foram esclarecidos o objeto da pesquisa e a metodologia de seleção dos pais: o sorteio dirigido. Foram escolhidos ao acaso uma turma de cada uma das séries de cada um dos ciclos e um número também ao acaso da lista de chamada de alunos de cada turma. A escola deveria verificar se, entre os sorteados, havia o mesmo número de alunos e alunas e se havia também nessa amostra pais casados e separados. Se não, partia-se para outro número da lista de chamada até se chegar a uma amostra equilibrada entre os sexos dos alunos e diversificada quanto ao estado civil dos responsáveis. Na segunda escola, que tem apenas o Ensino Médio, o diretor ponderou que deveria fazer o sorteio apenas com as turmas da $2^{\mathrm{a}}$ e da $3^{\mathrm{a}}$ série, pois os pais da $1^{\text {a }}$ série eram novos e teriam pouco conhecimento da escola até o momento.

Esse procedimento teve a intenção de explorar a diversidade e tornar a amostra a mais representativa possível, pois a variedade dos perfis dos participantes pode ampliar o "espectro de opiniões" (BAUER; GASKELL, 2003, p. 68) e favorecer a conversa com pais de bons e maus alunos, permitir comparações da visão sobre a educação escolar entre gêneros, discutir papéis sociais e as responsabilidades sobre a educação, além de investigar em que medida as novas configurações da família, com divórcios e novos casamentos, interferem no processo de escolarização de crianças e jovens.

Também se pretendeu evitar que as escolas indicassem apenas pais que pudessem avaliar positivamente o seu trabalho ou que mantivessem contatos mais frequentes 
com a direção ou a coordenação. Não houve esse sorteio dirigido nas entrevistas pilotos e observou-se essa mesma tendência nas instituições escolares procuradas anteriormente.

Depois da seleção, a escola estabeleceu o primeiro contato com os pais e as mães, explicando-lhes os objetivos da pesquisa e lhes perguntando se autorizavam o acesso a seus telefones. Se entre os selecionados houvesse alguns que não concordavam em serem entrevistados, a escola continuava o sorteio dirigido até chegar ao número estipulado (a intenção era entrevistar cinco casais ou mães de cada uma das escolas). Somente mediante a autorização deles é que as escolas informavam nomes e telefones.

\subsubsection{Os contatos iniciais}

A maioria dos contatos iniciais foi feita com as mães por telefone, porque as relações de nomes eram compostas mais por mães do que por pais. Em função do contato prévio da escola, elas já se mostraram informadas a respeito da pesquisa. Se eram casadas com o pai da criança ou do jovem, era solicitado que a conversa fosse com o casal; se eram separadas(os), a entrevista foi feita apenas com quem a criança ou

o jovem morava. Todavia, na terceira escola procurada, o contato inicial não foi muito esclarecedor, porque, ao entrar em contato direto e explicar como a entrevista deveria acontecer, algumas pessoas não aceitaram participar, alegando dificuldade de horário disponível.

Às vezes foram necessários mais alguns contatos telefônicos para combinar dia e horário conveniente para todos. E tudo foi organizado para que o encontro com os entrevistados fosse no local mais adequado para eles. Muitas entrevistas foram feitas nas casas dos entrevistados; outras, nos locais onde trabalham e ainda outras, em lugares públicos como livrarias e cafés. Sempre Ihes foi solicitada autorização para a gravação da conversa e também Ihes foi explicado como o material seria trabalhado posteriormente, ou seja, que seria transcrito e resumido.

Também se esclareceu que os entrevistados poderiam ter acesso tanto às gravações como às transcrições, se quisessem, e foi-lhes prometido o resumo das conversas que constaria do trabalho final para que verificassem se estavam fiéis ao 
que haviam dito e para que sugerissem modificações. Todos gostaram muito de ter essa oportunidade e autorizaram as gravações, o que pode consultado em ANEXO C.

\subsubsection{Critério de seleção das escolas}

Inicialmente considerou-se que um fator que poderia ampliar ainda mais a variedade dos perfis dos participantes seria a escolha de escolas com linhas pedagógicas distintas. Seriam procuradas tanto escolas mais tradicionais do ponto de vista pedagógico e disciplinar, quanto outras em que a disciplina não fosse tão rígida e que adotassem práticas pedagógicas mais interativas. Outro critério estipulado, com a finalidade de ampliação do espectro, foi o de usar os resultados dos alunos no Exame Nacional do Ensino Médio (ENEM) ${ }^{10}$. Então se entraria em contato com escolas cujos alunos tinham tido nos últimos dois anos bons resultados nas provas (entre as 15 primeiras escolas particulares), outras cujos resultados dos alunos tivessem sido regulares (entre as 50 primeiras) e, por último, as de resultados ruins (depois do centésimo lugar), pois se imaginou que esse fator poderia interferir na escolha dos pais pela escola e também indicar sua satisfação ou não com ela.

Entretanto, não foi fácil o acesso às escolas. Apesar de vários contatos telefônicos e de envios de mensagens eletrônicas solicitando uma conversa com a direção ou com a coordenação, não houve retorno e nem mesmo se conseguiu falar diretamente com os responsáveis. Em duas escolas, houve a autorização para a realização da pesquisa por parte da direção, mas os pais não a autorizaram a

10 O Exame Nacional do Ensino Médio foi concebido em 1998 com o objetivo de avaliar o desempenho do aluno ao término da escolaridade básica. Hoje os estudantes podem prestá-lo ao final da $3^{a}$ série do Ensino Médio ou mesmo depois e sua nota colabora para sua avaliação no vestibular das universidades públicas de diferentes maneiras e também servem para a participação no PROUNI, programa de bolsas em universidades particulares do governo federal. Aqui em São Paulo, na FUVEST, a nota do ENEM soma pontos à nota da primeira fase dos candidatos (ENEM http://www.enem.inep.gov.br/). Como é uma prova única, avaliando os mesmos conteúdos e habilidades, os resultados dos alunos no ENEM acabam gerando comparações entre as escolas. Eles são divulgados pelo Ministério da Educação todos os anos e alguns veículos de informação usam esses dados para fazer o que, na visão deles, seria um "ranking" das melhores escolas. Embora, neste trabalho, se entenda que a qualidade de ensino de uma escola não pode se restringir aos resultados dessa prova, afinal o seu currículo não se resume a apropriação de conteúdos por parte de seus alunos, considerou-se interessante também incluir esses resultados para verificar qual a importância que os pais atribuem a ele. 
informar seus telefones. Em uma delas, a diretora então solicitou que os próprios pais fizessem o primeiro contato, mas nenhum deles o fez. Não se sabe exatamente quantas escolas foram procuradas dessa maneira, mas acredita-se que tenha sido por volta de dez.

Diante dessa dificuldade, optou-se por procurar escolas em que a pesquisadora tinha algum contato pessoal (conhecia alguém da direção, coordenação ou mesmo do corpo de professores). Foi assim que se conseguiu a autorização para a realização da pesquisa e a colaboração de todos para realizar o sorteio dirigido e para os telefonemas iniciais com as famílias. E, dentre estas, procurou-se diferenciálas pelos resultados dos alunos no ENEM (bons, regulares e ruins).

Todavia, entre duas delas parece não haver diferenças significativas nas práticas pedagógicas e disciplinares, pois não são tão rígidas em termos de comportamento e também adotam a prática de ensinar a partir dos conhecimentos prévios dos alunos. São escolas de Educação Infantil até Ensino Médio. Já a outra é uma escola de ensino técnico, oferece apenas o Ensino Médio, com uma organização disciplinar um pouco mais rígida e com o ensino mais focado na exposição de conteúdos. Portanto, a variedade esperada nos perfis dos participantes pode não ter sido tão grande.

Segue uma breve descrição de cada uma das escolas:

Primeira Escola:

É um colégio religioso, fundado há mais de 50 anos e tem aproximadamente três mil alunos, da Educação Infantil até o Ensino Médio. Situa-se na zona oeste de São Paulo, numa área com 50 mil metros quadrados, com muito verde, e oferece atividades extracurriculares como Teatro, Treinamentos esportivos, Música, Ação Comunitária, entre outros. Obtém bons resultados no ENEM e se apresenta para a comunidade da seguinte maneira:

[...] realiza um projeto educacional amplo que se vale de três princípios: a tradição e o saber humanista do passado, a dimensão tecnológica e global, que aponta para o futuro; e a interação contínua com as necessidades e expectativas presentes. A pedagogia está voltada para desenvolver nos alunos o domínio crítico do conhecimento, a produção criativa e multicultural, a consciência política e a ação social. [...] a educação é um 
ideal e um compromisso. O homem inteligente é um ser livre. E a criança, desde o começo de sua existência racional, deve aprender que o acesso à liberdade é legítimo. Mas o homem só pode ser livre se for responsável. A vida escolar deve permitir aprender essa lição indispensável (GUIA ESCOLAS 2008, p. 138).

\section{Segunda Escola:}

É um colégio de Ensino Médio, localizado na região central da cidade e com fácil acesso ao metrô, que oferece também cursos técnicos nas áreas de Informática, Hotelaria, Publicidade, Gestão e Design de Jogos Eletrônicos, o que atrai jovens que procuram se preparar profissionalmente já nessa etapa da escolaridade e ingressar de maneira mais rápida no mercado de trabalho. Com aproximadamente 400 alunos, a escola também oferece cursos extracurriculares e é mantida por uma fundação sem fins lucrativos. Não obteve bons resultados nas últimas avaliações do ENEM e se apresenta para a comunidade da seguinte maneira:

Filosofia educacional: preparação para a continuidade dos estudos em nível
superior, especialmente para obter aprovação nos principais vestibulares e
para atingir ótimos resultados no ENEM. Formação para o mundo do
trabalho, com diferentes opções de aprendizado de técnicas valorizadas
pelo mercado e disciplinas optativas para definição de escolhas
profissionais futuras. Educação para a solidariedade e cidadania, com
envolvimento voluntário em atividades e programas de responsabilidade
social. Acompanhamento individualizado para valorizar potencial de
aprendizagem de cada aluno. Desenvolvimento de projetos
interdisciplinares com foco no desenvolvimento de habilidades e
competências (GUIA ESCOLAS 2008, p. 61).

Terceira Escola:

É um colégio com mais de 30 anos, também localizado na zona oeste da cidade de São Paulo e que oferece cursos desde a Educação Infantil até o Ensino Médio. Tem aproximadamente 800 alunos e funciona em duas unidades: uma para a Educação Infantil e Ensino Fundamental I e outra para Ensino Fundamental II e Ensino Médio. Oferece cursos extracurriculares, como Música e Atividades Esportivas. Obteve resultados regulares no ENEM e se apresenta para a comunidade da seguinte maneira: 
O trabalho do colégio consiste em dar forma e vida a um ideário em educação inspirado na convivência entre os ideais humanistas e o senso de realidade, ou seja, a necessidade de instrumentalizar os alunos para que tenham a possibilidade de realizar seus projetos de vida, tendo como perspectiva a contribuição para uma realidade social mais abrangente. Isso se materializa por meio de uma proposta pedagógica bastante detalhada, concebida cuidadosamente para cada etapa do desenvolvimento.[...] Os apelos em direção às mudanças da escola [...] a movem, por um lado, em direção a uma resistência ativa e problematizadora de seu papel. Por outro lado, a fazem buscar respostas que reforçam seu objetivo de formar alunos capazes de pensar, agir e criar projetos de vida (GUIA ESCOLAS 2008, p. 131).

\subsection{Participantes}

Os participantes foram casais ou mães da camada média ou média alta cujos filhos estudam em escola particular, ou seja, pessoas que podem pagar e, portanto, escolher uma escola para os filhos. Partiu-se do pressuposto de que essa possibilidade de escolha torna os pais mais rigorosos em relação aos serviços oferecidos. Se insatisfeitos, eles transferem os filhos para outra instituição. A intenção foi investigar o universo de valores desse público supostamente com mais expectativas em relação à educação escolar.

Em geral eram profissionais liberais, como advogados, psicólogos, jornalistas, veterinários, engenheiros, administradores, mas alguns eram comerciantes e um deles, empresário. Estabeleceu-se como critério não entrevistar pais educadores, uma vez que seriam, pelo próprio viés profissional, pessoas mais atentas e comprometidas com a escolaridade dos filhos. Também se considerou que, como a chamada crise de valores e de autoridade é mais percebida e debatida pela escola, eles poderiam ter uma reflexão mais sistemática sobre o assunto e a tendência de falarem mais como educadores do que como pais. Mas, embora nenhum professor de Educação Infantil ou do Ensino Médio tenha sido entrevistado, alguns professores universitários e uma psicóloga que trabalha como educadora acabaram fazendo parte do grupo. Esse dado será analisado posteriormente.

$\mathrm{Na}$ primeira escola procurada, os participantes foram quatro casais e uma mãe divorciada. Na segunda, dois casais, sendo que em um deles a esposa não era a mãe biológica; uma mãe separada; e outra mãe casada, cujo marido não participou da entrevista. Na terceira, dois casais e duas mães separadas. Portanto, ao todo foram entrevistadas 21 pessoas em 13 entrevistas. 
Inicialmente planejou-se entrevistar apenas pais cujos filhos estivessem no Ensino Fundamental II porque se considerou que quanto mais velhos os filhos, menos os pais acompanhariam sistematicamente o estudo e o dia-a-dia escolar deles e nesse ciclo se daria a transição de um acompanhamento mais sistemático para um mais pontual e esporádico. Entretanto, como a maioria dos casais e das mães tinha mais de um(a) filho(a), mais novos e mais velhos do que os que foram selecionados, os participantes acabaram falando da educação escolar de todos eles. Apenas dois casais (um da primeira escola e outro da segunda) e duas mães separadas (uma da segunda e outra da terceira) tinham apenas um filho ou filha.

\subsection{Material}

Foram realizadas entrevistas qualitativas "parcialmente estruturadas" (LAVILLE; DIONNE, 1999, p. 188), ou seja, com um roteiro prévio de questões feitas oralmente, nas quais se seguiu uma determinada ordem, mas com liberdade, de retirar algumas questões e/ou acrescentar outras, conforme outros temas relacionados ao principal surgiam. O roteiro comum de questões consta no ANEXO A.

É importante destacar que as entrevistas qualitativas têm sido muito utilizadas nas ciências humanas em geral. Seu ponto de partida "[...] é o pressuposto de que o mundo social não é um dado natural, sem problemas: ele é ativamente construído por pessoas em suas vidas cotidianas, mas não sob condições que elas mesmas estabeleceram" (BAUER; GASKELL, 2003, p 65).

Nesse sentido, esse instrumento foi empregado no presente trabalho para se "mapear e compreender [...] o universo de valores, crenças, atitudes e motivações" (p. 65) dos pais em relação à educação que oferecem como pais e também à proporcionada pela escola. Como a relação com os filhos e com a escola geralmente mobiliza diversos aspectos afetivos, as entrevistas se mostraram um instrumento adequado. "Seu caráter de interação permitiu a construção de um clima de influência recíproca entre quem perguntou e quem respondeu" (LÜDKE; ANDRÉ, 1988) e o(s) entrevistado(s) discorreram livremente sobre o assunto abordado. 
Tratando-se de pesquisa sobre o ensino, a escola e seus problemas [...] podemos estar seguros de que, ao entrevistarmos professores [...] até mesmo pais de aluno não Ihes estaremos certamente impondo uma problemática estranha, mas, ao contrário, tratando com eles de assuntos que Ihes são muito familiares e sobre os quais discorrerão com facilidade (p.35 e 36).

\subsection{Procedimento}

As entrevistas, em geral, iniciavam-se com uma apresentação da pesquisadora: dados pessoais, instituição a que estava vinculada e o tema da pesquisa. Em seguida foram feitos os esclarecimentos sobre seus objetivos e sobre o método de escolha dos pais dos alunos, ou seja, o sorteio dirigido. Alguns participantes já se mostraram informados sobre tudo isso em função do contato inicial da escola; outros se manifestavam surpresos pelo fato de a escola os ter indicado - isso aconteceu mais com os pais da terceira escola que tinham filhos que não tinham um desempenho muito bom ou quando se mostravam mais críticos em relação à instituição. Quando Ihes era explicado que não havia sido propriamente uma indicação da escola, eles entendiam. Em seguida, era-lhes perguntado se autorizavam a gravação da conversa e Ihes garantido o anonimato, além da certeza de que as informações seriam utilizadas exclusivamente para estudo.

Toda essa apresentação e as explicações iniciais faziam com que um clima mais informal se estabelecesse, e não houve necessidade de se realizar uma fase de "aquecimento", partindo-se, portanto, para as questões previamente elaboradas. O que se observou é que ao responder a pergunta inicial (Por que escolheram a escola tal?), os entrevistados acabavam respondendo também a seguinte ( $O$ que vê de bom nela?). Dessa forma, antes de Ihes fazer a segunda pergunta, procurou-se expor o que foi compreendido do que havia sido dito e depois era perguntado: "O que mais veem de bom na escola?". Na verdade, a elaboração de pequenas sínteses, questões de esclarecimento, de aprofundamento e focalizadoras (ALMEIDA; BRANDINI, 2004), foram feitas em todas as entrevistas e em vários momentos com a intenção de manter o foco no tema relação família-escola e no acompanhamento da vida escolar dos filhos (as). Muitos pais tinham uma tendência de falar das características da personalidade e do comportamento dos filhos, assim como do relacionamento entre eles. 
Nunca os entrevistados se colocaram de maneira passiva na entrevista, pelo contrário, queriam saber quais eram os objetivos da pesquisa, por que tinham sido eles os escolhidos, quais seriam as próximas etapas. Alguns até perguntaram quais eram as conclusões até o momento. Portanto, não só se mostraram receptivos e colaboradores, como muitos revelaram que também se interessavam pelo estudo.

\begin{abstract}
A concordância do entrevistado em colaborar na pesquisa já denota sua intencionalidade - pelo menos de ser ouvido e considerado verdadeiro no que diz -, o que caracteriza o caráter ativo de sua participação [...] está aceitando os interesses de quem está fazendo a pesquisa, ao mesmo tempo em que descobre ser o dono de um conhecimento importante para o outro (ALMEIDA; BRANDINI, 2004, p. 12 e 13).
\end{abstract}

Quando a entrevista foi feita com o casal, teve a duração média de uma hora e trinta minutos; e apenas com a mãe, uma hora. Ao término de algumas delas, os próprios entrevistados quiseram fazer uma síntese das suas ideias. Durante a despedida, depois dos agradecimentos, forneciam cartões de visita ou endereços eletrônicos para o envio do resumo da entrevista. Especialmente em duas delas, cujos participantes foram casais, eles agradeceram a oportunidade de conversar entre eles sobre o assunto. Esse fato indica que "a entrevista também se torna um momento de organização de ideias e de construção de um discurso para o interlocutor, [...] acaba por colocar o entrevistado diante de um pensamento organizado de uma forma inédita até para ele mesmo" (ALMEIDA; BRANDINI, 2004, p. 14).

No processo de transcrição, num primeiro momento foi feito um esforço para passar da linguagem oral para a escrita as falas tais como elas se deram, ou seja, com vícios de linguagem, erros gramaticais, onomatopéias, etc. Depois, numa segunda versão, procurou-se eliminar um pouco esses aspectos da oralidade, mas sem substituições de termos. Após esse trabalho, foi feito um resumo do material para deixar apenas o conteúdo do que foi discutido nas entrevistas, sem as descrições de ambientes, dos comportamentos dos entrevistados e outros acontecimentos ocorridos. 
Embora todos esses aspectos tenham importância, considerou-se que poderiam desviar o foco dos entrevistados das suas próprias ideias sobre a educação escolar e levá-los a se sentirem analisados pessoalmente, o que não era objetivo nem da entrevista nem do trabalho. $O$ intervalo de tempo entre as transcrições $e$ as elaborações dos resumos foi de aproximadamente quatro semanas. Então os resumos foram enviados aos participantes, juntamente com o esclarecimento de que deveriam lê-los, avaliar sua fidelidade e dar sugestões de possíveis alterações. Um exemplo de e-mail enviado pode ser visto no ANEXO B.

Talvez em função do tempo entre a entrevista e o envio do resumo, poucos participantes se manifestaram, mesmo quando, por telefone, era-lhes perguntando se haviam recebido e lido o material. A resposta mais comum foi a que haviam recebido, mas não tinham tido tempo de ler e não havia sido estipulado um prazo para que fizessem isso. Apenas cinco responderam ao e-mail diretamente, sendo que três entrevistados afirmaram que o texto estava fiel ao que havia sido conversado e dois sugeriram pequenas mudanças, que foram incluídas sem restrições. 


\section{CAPÍTULO 3}

\section{RESULTADOS:}

\subsection{Etapas da análise de resultados}

Mais do que expor e comparar teorias e métodos de análise dos resultados, pretende-se neste tópico descrever as etapas desenvolvidas com o material recolhido nas entrevistas. O que se buscou fazer foi uma análise de conteúdo, aqui entendida como uma maneira de reorganizar os dados para que outros sentidos, além do aparente, fossem revelados ou reconstruídos (LAVILLE \& DIONNE). Esse "não é, contudo, um método rígido, no sentido de uma receita com etapas bem definidas, em que basta transpor os dados numa ordem determinada para ver surgirem belas conclusões" (1999, p. 216). Como já foi descrito no Método, as entrevistas foram primeiramente transcritas, depois reescritas com a intenção de diminuir aspectos da oralidade e, finalmente, resumidas. No trabalho de resumo priorizou-se ressaltar a especificidade e a coerência interna de cada entrevista, sem a preocupação de estabelecer semelhanças e diferenças entre elas, embora tenha sido utilizada a mesma estrutura em todas elas - a seqüência das perguntas.

Foi só após esse trabalho que os dados foram organizados de forma mais comparativa. A partir das respostas de cada entrevistado, para cada uma das perguntas foi construído um quadro tal com o apresentado abaixo:

\section{Resultados da Primeira Escola}

\begin{tabular}{|l|l|}
\hline Por que escolheram esta escola? & $\begin{array}{l}\text { O filho que quis ir para lá principalmente } \\
\text { porque um amigo iria, mas também por }\end{array}$ \\
causa do espaço físico, da parte \\
esportiva e por ser uma escola grande. \\
- $\begin{array}{l}\text { Tinham amigos que estudaram lá e } \\
\text { gostavam muito da escola. } \\
\text { - Conheciam pessoas vinculadas ao } \\
\text { colégio, ex-alunos ou professores, que } \\
\text { julgavam serem pessoas "curiosas", "que } \\
\text { acham que aprender é legal", "ligadas a } \\
\text { área de humanas e com valores } \\
\text { humanos", pareciam ter mais clareza de }\end{array}$
\end{tabular}




\begin{tabular}{|c|c|}
\hline & 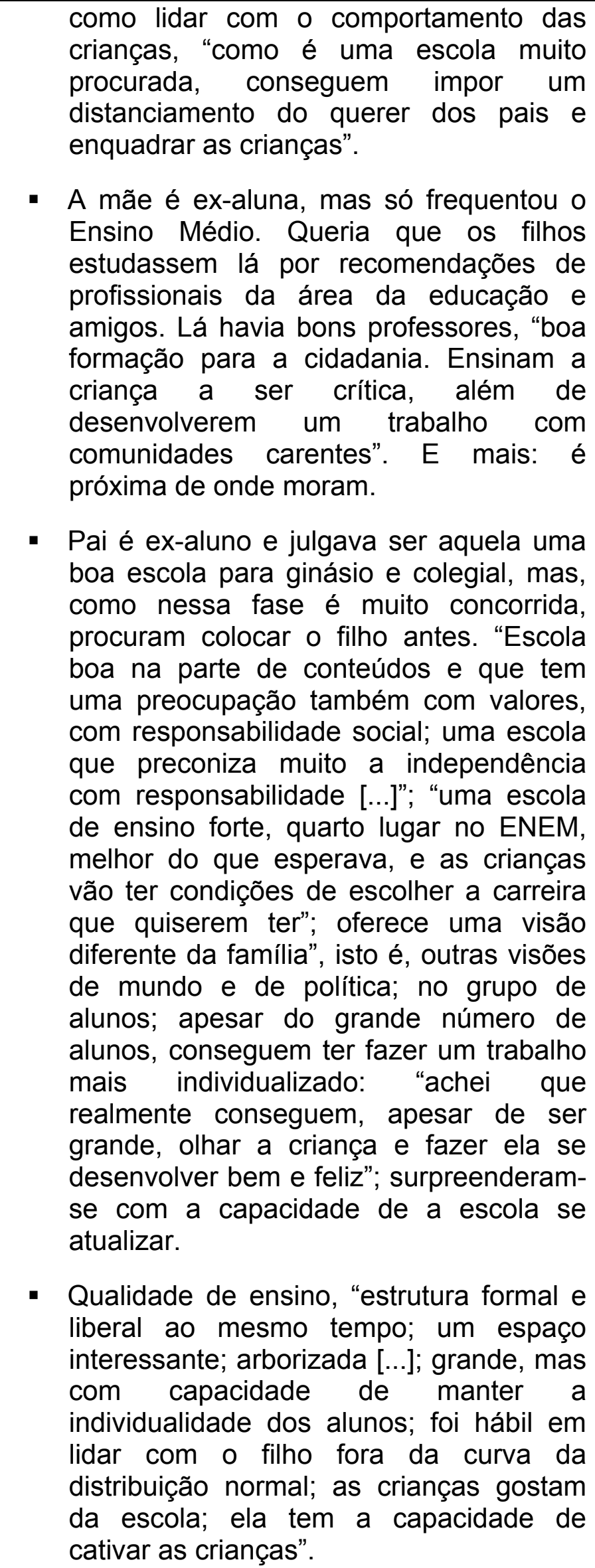 \\
\hline
\end{tabular}




\begin{tabular}{|l|l|}
\hline & $\begin{array}{l}\text { Ensino de qualidade; valores humanos; } \\
\text { postura crítica; estrutura formal e liberal; } \\
\text { apesar do grande número de alunos, tem a } \\
\text { capacidade de olhar para as necessidades } \\
\text { de cada um; diversidade de pessoas e de } \\
\text { visões de mundo. }\end{array}$ \\
\hline
\end{tabular}

Resultados da Segunda Escola

\begin{tabular}{|c|c|}
\hline $\begin{array}{l}\text { Há quanto tempo os filhos estudam } \\
\text { nesta escola? }\end{array}$ & $\begin{array}{l}\text { - Dois anos. } \\
\text { - Dois anos. } \\
\text { - Um ano e meio. } \\
\text { - Dois anos. } \\
\text { A escola só tem ensino Médio, e os filhos } \\
\text { foram para lá na } 1^{\text {a }} \text { série do EM. }\end{array}$ \\
\hline Por que escolheram esta escola? & $\begin{array}{l}\text { - Antes os filhos estudaram numa escola } \\
\text { Waldorf por identidade com a } \\
\text { pedagogia. Para a mãe: "participação } \\
\text { dos pais", e para o pai: "método de } \\
\text { alfabetização bastante gradual e } \\
\text { valorização dos aspectos lúdicos". Foi } \\
\text { indicação de amigos e gostaram do } \\
\text { diretor, da proposta humanista, dos } \\
\text { professores: "os alunos são tratados de } \\
\text { uma maneira mais solta". Por ser numa } \\
\text { região central e perto do metrô, há uma } \\
\text { diversidade grande de pessoas, "se } \\
\text { convive com vários tipos de pessoas, da } \\
\text { cidade inteira, não tem aquela coisa de } \\
\text { gueto", atendimento pessoal, o diretor } \\
\text { conhecia os alunos. tificuldade de } \\
\text { Antes: filho com dificulda numa } \\
\text { aprendizagem, sofreu muito nu } \\
\text { escola tradicional e procurou uma } \\
\text { escola Waldorf. Escola atual: indicação } \\
\text { de amigos, atendimento do diretor, bons } \\
\text { professores, alunos não usavam } \\
\text { uniforme, filho quis ir para lá. } \\
\text { Antes: Uma escola de bairro, a melhor } \\
\text { particular da região. Atual: Indicação do } \\
\text { pai de uma amiga que era ex-aluno; } \\
\text { ensino técnico; escolha da filha, que } \\
\text { madrasta resistiu um pouco porque não } \\
\text { queria que a enteada fosse influenciada } \\
\text { pelas amigas. Pai: "eu queria que ela }\end{array}$ \\
\hline
\end{tabular}




\begin{tabular}{|c|c|}
\hline & $\begin{array}{l}\text { fizesse um colégio técnico, porque é } \\
\text { uma coisa que deu muito certo para } \\
\text { mim [...] antes de sair do colégio, já tem } \\
\text { uma base profissional". } \\
\text { - Antes: escola construtivista, com um } \\
\text { espaço adequado, fazia um trabalho de } \\
\text { formação também com os pais, } \\
\text { explicando o processo de alfabetização, } \\
\text { por exemplo. Atual: apresentação do } \\
\text { diretor da escola, preocupação com a } \\
\text { formação mais global, trabalho com } \\
\text { esporte, obriga a filha a conhecer o } \\
\text { centro e a andar de metrô, grupo de } \\
\text { alunos da escola anterior também foi, } \\
\text { além de ser maior que a anterior, mas } \\
\text { não ser muito grande. } \\
\text { A figura do diretor parece ter sido decisiva } \\
\text { na escolha da escola. Indicação de amigos } \\
\text { também. O fato de ser uma escola técnica } \\
\text { foi decisivo apenas para um dos pais. }\end{array}$ \\
\hline $\begin{array}{l}\text { O que mais veem de bom nesta } \\
\text { escola? }\end{array}$ & $\begin{array}{l}\text { - O fato de todos entrarem no EM facilita } \\
\text { a adaptação dos alunos; a maneira } \\
\text { como a escola lidou com um problema } \\
\text { de drogas: "trataram com muita } \\
\text { objetividade, não se buscou uma coisa } \\
\text { de segregar [...] e uma discussão de } \\
\text { qualidade."; tem conteúdo, dá ênfase ao } \\
\text { vestibular na } 3^{a} \text { série; o fato de se } \\
\text { trabalhar com representantes de sala; } \\
\text { boa relação direção-alunos. } \\
\text { Boa estrutura, boa biblioteca, boa } \\
\text { organização, o diretor conhecer os } \\
\text { alunos; os pais conseguem ser ouvidos, } \\
\text { não se distancia dos pais; bom trabalho } \\
\text { de preparação para o vestibular. } \\
\text { Informam aos pais sobre o } \\
\text { comportamento dos alunos: se estão se } \\
\text { atrasando, se não levaram material, etc; } \\
\text { são atentos à segurança (não pode sair } \\
\text { sem autorização, tem funcionários no } \\
\text { caminho entre a escola e o metrô; são } \\
\text { ágeis na comunicação com os pais: } \\
\text { "bastante informatizados; não há um } \\
\text { padrão de comportamento entre os } \\
\text { estudantes: "cada um o seu modo de } \\
\text { ser"; o nível de educação; não } \\
\text { permitirem fumar, namorar, deixando } \\
\text { claro que a escola é lugar para estudar. }\end{array}$ \\
\hline
\end{tabular}




\begin{tabular}{|c|c|}
\hline & $\begin{array}{l}\text { - O trabalho com a escolha profissional; a } \\
\text { sistemática de avaliação (o aluno pode } \\
\text { fazer outra prova sobre o mesmo } \\
\text { conteúdo para melhorar sua nota), o } \\
\text { fato de o diretor ser muito atento aos } \\
\text { alunos e manter contato constante com } \\
\text { os pais. } \\
\text { Parece que a segunda escola tem menos } \\
\text { pontos positivos em comum do que as } \\
\text { outras. Mas a relação de diálogo que a } \\
\text { direção mantinha com os alunos e o fato de } \\
\text { a escola informar aos pais, de maneira } \\
\text { eficiente, sobre o comportamento dos } \\
\text { alunos, são aspectos importantes para os } \\
\text { pais. }\end{array}$ \\
\hline O que veem de ruim nesta escola? & $\begin{array}{l}\text { Mudança de diretor; mudança na equipe } \\
\text { de professores (alguns saíram e outros } \\
\text { passaram a dar aulas para a } 1^{a} \text { série e } \\
\text { não para a } 3^{a} \text { ) que acarretou queda na } \\
\text { qualidade de ensino; escola ficou com } \\
\text { cara de empresa; estrutura pequena } \\
\text { (pouco orientadores para o número de } \\
\text { alunos); o novo diretor não conhece tão } \\
\text { bem os alunos e suas famílias; } \\
\text { estabelece menos diálogo com os } \\
\text { alunos; má condução no problema com } \\
\text { uma professora. } \\
\text { - A mudança de diretor; o atual "ouve, } \\
\text { mas não se envolve"; a transferência do } \\
\text { grupo de professores melhores para a } \\
1^{a} \text { série, o que para ela indica que há } \\
\text { uma mudança de visão dos "donos" da } \\
\text { escola. } \\
\text { - Não veem nada de ruim. } \\
\text { - Mudanças constantes de direção, pouca } \\
\text { capacidade de manejar problemas de } \\
\text { grupo. } \\
\text { A mudança de diretor parece ter afetado } \\
\text { principalmente os alunos e pais com mais } \\
\text { tempo na escola (3a série). Uma prática mais } \\
\text { democrática da escola parecia estar na figura } \\
\text { do diretor e não nas práticas da escola em si. } \\
\text { O pai que demonstra ter outro perfil, mais } \\
\text { autoritário, nem cita a saída do outro diretor } \\
\text { como um problema. }\end{array}$ \\
\hline
\end{tabular}




\begin{tabular}{|c|c|}
\hline Reunião de pais & $\begin{array}{l}\text { - Mãe é quem vai, o pai vai apenas } \\
\text { quando há um problema afetando muito } \\
\text { as filhas. } \\
\text { - Mãe é quem vai tanto nas coletivas } \\
\text { como nas individuais. } \\
\text { - Vão os dois: pai e madrasta. } \\
\text { - Mãe é quem vai mais; pai vai quando a } \\
\text { filha cobra. }\end{array}$ \\
\hline Como avaliam as reuniões? & $\begin{array}{l}\text { - "Eu acho que é o que dá para fazer, } \\
\text { porque tem que ser mais objetiva, tem } \\
\text { que falar da programação [...] enfim, } \\
\text { elas são estruturadas. [...]. E. eu acho } \\
\text { chato, mas não sei se teria outra forma," } \\
\text { (principalmente o fato de ter que ficar } \\
\text { numa fila para falar com o professor), } \\
\text { "[...] sempre nessas reuniões, você } \\
\text { acaba sendo educado também! [...] } \\
\text { essas reuniões de pais, se forem bem } \\
\text { preparadas pela escola, elas funcionam } \\
\text { como um processo de educação para os } \\
\text { pais."(pai), "as reuniões são essenciais, } \\
\text { [...] elas podem ser mais bem } \\
\text { organizadas, mas é essencial esse } \\
\text { contato" (pai). } \\
\text { "Eu particularmente não gosto muito da } \\
\text { reunião [...] é só para você pegar } \\
\text { informação." Algumas reuniões em que } \\
\text { houve palestras sobre adolescência e } \\
\text { drogas foram avaliadas positivamente, } \\
\text { mas deixaram de acontecer. } \\
\text { "Eu acho importantíssimo a reunião de } \\
\text { pais [...] é o momento de você olhar o } \\
\text { professor e ele te olhar também [...] } \\
\text { você é obrigado a participar, mesmo } \\
\text { que não goste. A escola deveria } \\
\text { promover mais ações que integrassem } \\
\text { os pais". É uma possibilidade de } \\
\text { conversar com todos os professores: "a } \\
\text { reunião de pais, quando nós dois } \\
\text { vamos, ela fica feliz" (madrasta). } \\
\text { "Reunião de pais, eu vou te falar uma } \\
\text { coisa... Eu não sei direito ainda qual } \\
\text { seria o modelo". A estrutura é de uma } \\
\text { fala mais geral para todos, depois os } \\
\text { pais procuram os professores para } \\
\text { conversar sobre o filho, "e aí não tem } \\
\text { jeito: é fila!". O modelo da outra escola } \\
\text { em que um ou dois professores }\end{array}$ \\
\hline
\end{tabular}




\begin{tabular}{|c|c|}
\hline & $\begin{array}{l}\text { participavam explicando o seu trabalho } \\
\text { é elogiado: "Quando o professor fala do } \\
\text { projeto que ele desenvolveu [...] você vê } \\
\text { que é diferente, são coisas que [...] você } \\
\text { não consegue perceber pela fala do } \\
\text { aluno". } \\
\text { Apesar da quase unânime percepção de que } \\
\text { as reuniões são chatas, todos reconhecem a } \\
\text { sua importância. Vale destacar que alguns pais } \\
\text { dizem claramente que eles próprios acabam } \\
\text { sendo educados nesse contato com a escola, } \\
\text { principalmente quando a escola "explica" a } \\
\text { fase de desenvolvimento pela qual os filhos } \\
\text { estão passando, ou quando se discute } \\
\text { problemas como o das drogas. }\end{array}$ \\
\hline $\begin{array}{l}\text { Como acompanha o estudo do(s) } \\
\text { filho(s)? }\end{array}$ & $\begin{array}{l}\text { Pouco, pois buscam fazer mais um } \\
\text { acompanhamento afetivo e psicológico } \\
\text { do que de aproveitamento, "porque uma } \\
\text { coisa está vinculada à outra" (mãe); } \\
\text { procuram conversar bastante com os } \\
\text { filhos sobre qualquer coisa, "não } \\
\text { adianta, você tem que ter um tempo, } \\
\text { tem que se disponibilizar, [...] é no café } \\
\text { da manhã, é no almoço e no jantar" } \\
\text { (mãe). A filha tinha terminado um } \\
\text { namoro e eles foram à escola contar } \\
\text { isso para os professores, pois, como } \\
\text { imaginavam, o aproveitamento dela caiu } \\
\text { em função disso. } \\
\text { Não estuda junto, mas é notificada pela } \\
\text { escola sobre a época das provas e } \\
\text { então pergunta para o filho se estudou, } \\
\text { se fez lição, etc. Quando tem alguma } \\
\text { questão sobre o aproveitamento, } \\
\text { procura e escola. O marido não } \\
\text { acompanha nada, só cobra o boletim e } \\
\text { tira dúvidas de matemática, porque é } \\
\text { engenheiro: "fica total comigo" (mãe). O } \\
\text { pai também não participou da decisão } \\
\text { da escola. } \\
\text { Estudam junto com a filha quando } \\
\text { observam que ela não está } \\
\text { acompanhando. Também restringem o } \\
\text { uso de telefone, internet e televisão. } \\
\text { Mas atualmente a filha tem estudado } \\
\text { mais sozinha. Acompanham também a } \\
\text { questão do comportamento na escola e } \\
\text { por duas vezes foram notificados de }\end{array}$ \\
\hline
\end{tabular}




\begin{tabular}{|l|l|}
\hline atitudes inadequadas da filha e \\
conversaram com ela dando razão à \\
escola. Principalmente a madrasta, que \\
acabou desenvolvendo uma relação \\
mais próxima com a enteada, é muito \\
atenta aos relacionamentos afetivos e \\
às amizades dela. \\
Quando a filha era menor, fazia lição \\
junto, procurava instituir uma rotina e \\
uma disciplina de não fazer lição com \\
televisão ligada, etc. Procurava a escola \\
quando alguma coisa não lhe parecia \\
bem (por exemplo, a filha escrevia com \\
muitos erros de português). Agora \\
eventualmente estuda uma matéria ou \\
outra que pode ajudar (matemática \\
não!). Procura orientar na organização, \\
não em conteúdos. Com a separação, o \\
pai passou a participar mais de alguns \\
eventos escolares, como apresentações \\
de trabalho, jogos, etc. Ele também se \\
mostrou preocupado com a questão do \\
vestibular. Do acompanhamento diário e \\
da escolha das duas escolas ele não \\
participou. \\
Pais em geral se mostram mais atentos aos \\
aspectos afetivos do que ao \\
aproveitamento objetivo dos filhos na \\
escola. Procuram orientá-los em aspectos \\
mais amplos, mas alguns estudam quando \\
verificam que o filho precisa.
\end{tabular}

Resultados da Terceira Escola

\begin{tabular}{|l|l|}
\hline Há quanto tempo o filho estuda? & $\begin{array}{l}\text { Desde a } 1^{\mathrm{a}} \text { série (está no } 7^{\circ} \text { ano, antiga } \\
\end{array}$ \\
& $6^{\mathrm{a}}$ série) \\
- & Dois anos (está $3^{\mathrm{a}}$ série EM) \\
- & Desde a $1^{\mathrm{a}}$ série (um está $8^{\circ}$ ano, antiga \\
& $7^{\mathrm{a}}$ série; o outro está na $2^{\mathrm{a}}$ série EM) \\
- & Desde a $1^{\mathrm{a}}$ série (um está na $1^{\mathrm{a}}$ série; a \\
& filha já saiu) \\
& Pais conhecem bem a escola. \\
\hline Por que escolheram esta escola? & $\begin{array}{l}\text { Amigos e pais da escola de Educação } \\
\text { Infantil queriam ficar juntos. Achou a } \\
\text { escola "acolhedora" (estava se se } \\
\text { separando), gostou da proposta }\end{array}$ \\
\hline
\end{tabular}




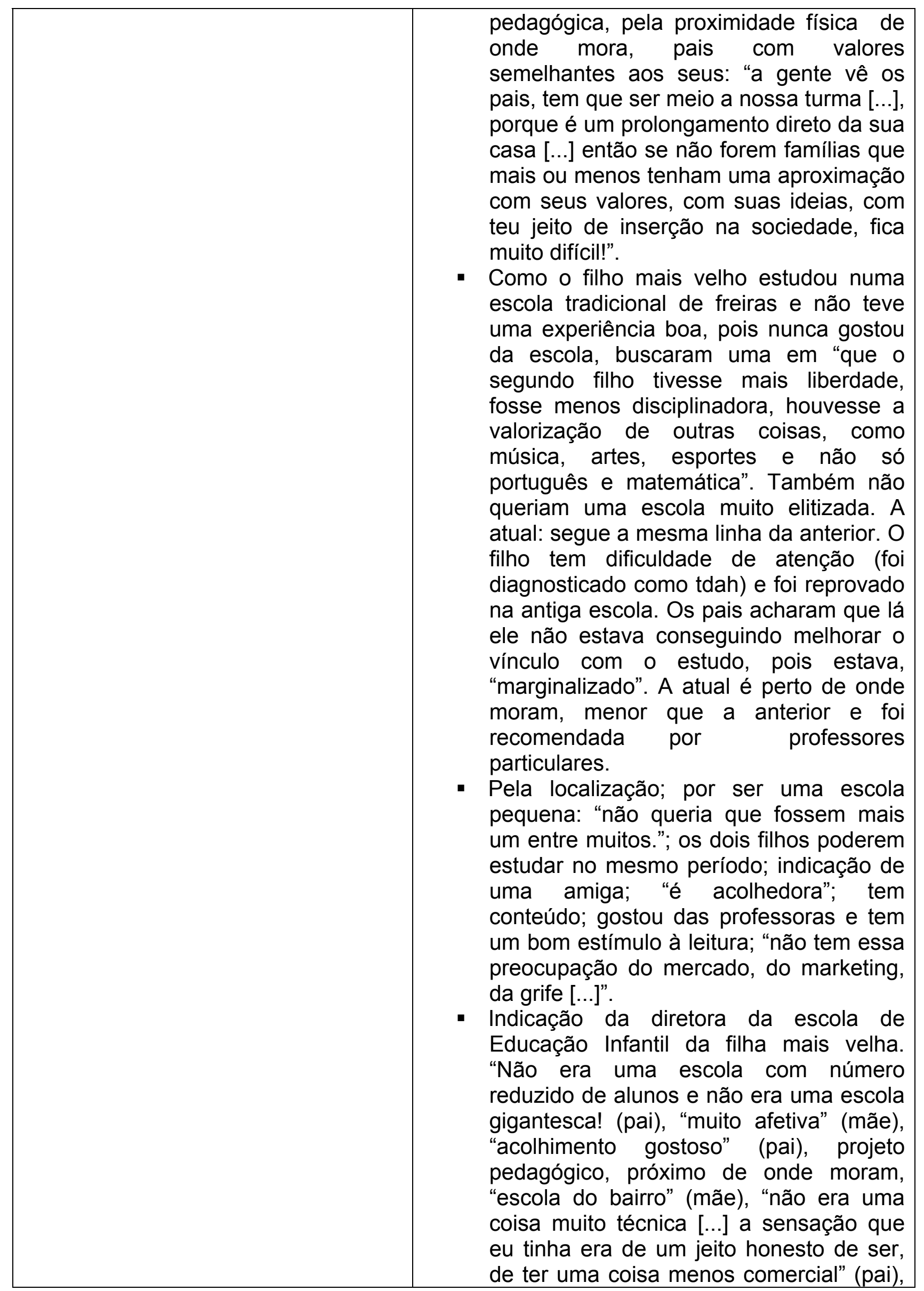




\begin{tabular}{|l|l|}
\hline & preocupação em explicar aos pais a \\
proposta de trabalho, ensino mais crítico, \\
menos focado na informação, relação \\
comercial boa. \\
Acolhimento e localização parecem palavras \\
chaves para a escolha por esta escola. \\
\hline Atenta aos alunos, bom trabalho de \\
relacionamento entre eles, agora está se \\
preocupando mais em exigir mais estudo \\
dos alunos, "a importância dos alunos se \\
organizarem em casa e não só quando \\
está na escola, [...] a importância de \\
estudar todo dia [...]", o fato de os alunos \\
lerem muito e também os estudos do \\
meio... \\
Os coordenadores, pois "a mensagem é \\
mais direta [...] faz um caminho legal, que \\
ele sai de outra forma, motivado, tem \\
feedback não só do resultado, mas \\
comportamental também." (pai); "o que \\
ele traz, a gente se identifica" (mãe); \\
"curiosidade aguçada" (pai); os alunos \\
são interessados em entender o que está \\
acontecendo no mundo; a escola é \\
formadora de opinião; interação entre os \\
alunos; a parte esportiva. \\
O trabalho de conclusão de curso "ensina \\
o aluno a pesquisar"; os professores: \\
"eles têm uma boa formação e um bom \\
jeito de conduzir a conversa com os \\
meninos"; aulas de teatro; currículo \\
complementar, como astronomia e \\
psicologia; o ambiente: "as famílias estão \\
mais ou menos próximas da minha \\
condição de vida, tanto de poder \\
aquisitivo, quanto de valores [...]"; os \\
coordenadores; o trabalho em relação às \\
drogas: "eles chamam as familias quando \\
percebem que o aluno faz isso, mas eu \\
acho que ainda não têm o controle". \\
A escolha do material didático, com livros \\
atualizados, complementados por \\
materiais elaborados pelos próprios \\
professores; os professores: "eles são \\
envolvidos com o projeto pedagógico"; o \\
planejamento de ensino com normas para \\
cada série; os estudos do meio; a área de \\
artes e a esportiva; o espaço físico; a \\
interação entre os alunos; o trabalho de
\end{tabular}




\begin{tabular}{|c|c|}
\hline & $\begin{array}{l}\text { "tese" que os alunos fazem na } 2^{a} \text { série do } \\
\text { Ensino Médio: "não é uma proposta } \\
\text { acadêmica [...], mas é pegar um tema, } \\
\text { aprofundar um pouco [...] é muito legal!" }\end{array}$ \\
\hline & $\begin{array}{l}\text { Algumas coincidências: o trabalho com } \\
\text { leitura, a parte esportiva, o trabalho de } \\
\text { conclusão de curso, os coordenadores, a } \\
\text { interação entre os alunos. Há algumas } \\
\text { divergências: a parte artística e os estudos } \\
\text { do meio. }\end{array}$ \\
\hline O que veem de ruim na escola? & $\begin{array}{l}\text { - A proposta de Educação Artística; a } \\
\text { dificuldade em colocar limites para os } \\
\text { alunos (característica mais forte na EFI } \\
\text { que se juntou com a atual); não são tão } \\
\text { exigentes com o estudo dos alunos; difícil } \\
\text { acesso dos pais aos professores; pouco } \\
\text { intercâmbio entre pais, professores e } \\
\text { escola: "as escola só se coloca para } \\
\text { refletir sobre as críticas que são feitas } \\
\text { quando percebe que há uma evasão de } \\
\text { alunos, porque, de outro modo, [...] eles } \\
\text { se colocam numa postura muito } \\
\text { defensiva [...]"; em alguns momentos se } \\
\text { mostram incoerentes: } \\
\text { democrático e discurso } \\
\text { professores veem pouco os materiais dos } \\
\text { alunos, amassados, descuidados ou com } \\
\text { erros ortográficos; a comunicação é ruim, } \\
\text { pois as cartas são mal redigidas e muitas } \\
\text { vezes os pais não tem retorno. } \\
\text { Não sabem exatamente como se dá a } \\
\text { preparação para o Vestibular, quão bem } \\
\text { preparados os alunos saem; embora } \\
\text { reconheçam que o filho não se envolve } \\
\text { muito com questões como escolha } \\
\text { profissional, ENEM e outras atividades, } \\
\text { acham que a escola poderia se } \\
\text { comunicar mais diretamente com os pais } \\
\text { por meio de e-mails, etc. } \\
\text { A fusão fez a escola perder um pouco sua } \\
\text { identidade (mas agora está recuperando); } \\
\text { muita falta e troca de professores; } \\
\text { dificuldade em conversar direto com os } \\
\text { professores; os estudos do meio: "os } \\
\text { estudos do meio [...] agregam muito } \\
\text { pouco [...] é custoso pagar, é bacana } \\
\text { para eles (alunos), mas eu acho que o } \\
\text { resultado cognitivo em relação ao custo } \\
\text { [...] é muito baixo!"; saída de alguns }\end{array}$ \\
\hline
\end{tabular}




\begin{tabular}{|c|c|}
\hline & $\begin{array}{l}\text { professores e coordenadores que eram } \\
\text { tradicionais da escola; a obrigação de o } \\
\text { aluno ler nas férias e não quando achar } \\
\text { melhor; não sentem que suas críticas } \\
\text { sejam encaminhadas: "eu sou bem } \\
\text { recebida, mas as ideias param numa } \\
\text { parede! [...] A escola já tem um discurso } \\
\text { preparado, [...] cristalizado". Um } \\
\text { sentimento de desconfiança: "acho que a } \\
\text { escola é muito cara pelo que ela } \\
\text { proporciona [...], eu fico desconfiada que } \\
\text { os donos da escola lucram muito mais do } \\
\text { que eu acho que o bom senso exigiria } \\
\text { [...]". } \\
\text { Contradição e conflitos entre o projeto } \\
\text { pedagógico e e as questões } \\
\text { administrativas, mandando embora } \\
\text { professores que representavam a } \\
\text { identidade da escola; nem sempre dão } \\
\text { conta da proposta, principalmente no } \\
\text { Ensino Médio; falta ter mais contato e } \\
\text { participar mais da escola, mas acha que } \\
\text { de fato não são poucos os espaços que a } \\
\text { escola oferece até porque percebe que a } \\
\text { adesão dos outros pais é pequena; a } \\
\text { questão das drogas (houve algumas } \\
\text { tentativas de se trabalhar a questão, mas } \\
\text { percebem que ainda é um ponto delicado: } \\
\text { (pai) "você não tem uma coisa muito } \\
\text { nítida a esse respeito"; em momentos de } \\
\text { crise assume uma postura autoritária } \\
\text { para pais e alunos (expulsão de alunos } \\
\text { por problemas de comportamento ou } \\
\text { envolvimento com drogas). } \\
\text { Chama a atenção o fato de os pais não } \\
\text { centirem que têm uma boa comunicação com a } \\
\text { escola, desde os problemas mais pontuais (o } \\
\text { esclarecimento de uma circular) até um tema } \\
\text { mais complexo como drogas. Sentem que não } \\
\text { há "acolhimento". }\end{array}$ \\
\hline Reunião de pais & $\begin{array}{l}\text { Mãe vai, pai não e nunca foi (separados). } \\
\text { Normalmente a mãe vai nas coletivas, o } \\
\text { casal vai junto nas individuais, mas o pai } \\
\text { eventualmente também vai nas coletivas, } \\
\text { apesar de não gostar. } \\
\text { - Vai sempre, o pai também, quando pode } \\
\text { (separados). } \\
\text { - A mãe vai mais que o pai, mas o pai } \\
\text { também vai. }\end{array}$ \\
\hline
\end{tabular}




\begin{tabular}{|c|c|}
\hline Como avaliam as reuniões de pais? & $\begin{array}{l}\text { - "Eu sou do tipo que gosta de ir às } \\
\text { reuniões: [...] acho que é um blábláblá } \\
\text { importante de ouvir [...] é o momento de } \\
\text { você justamente checar aquilo que está } \\
\text { sendo proposto.", "tem coisas que você } \\
\text { não vai pulando de alegria, mas dessa } \\
\text { última eu saí superestimulada, fiquei } \\
\text { super bem impressionada". } \\
\text { "(pai): Eu acho um saco aquilo lá! } \\
\text { Pessoas que monopolizam a reunião com } \\
\text { assuntos que não interessam à maioria } \\
\text { dos pais, e a escola não consegue cortar } \\
\text { esse tipo de situação";mãe acha que } \\
\text { poderia ter mais, pois gostava das } \\
\text { reuniões em que os professores } \\
\text { apresentavam seus trabalhos, permitindo } \\
\text { aos acompanharem melhor; acha que a } \\
\text { escola poderia atuar mais duramente com } \\
\text { esse tipo de pais. } \\
\text { "Eu, na verdade, gosto das reuniões. } \\
\text { Tanto é que eu sinto falta delas.", "acho } \\
\text { que a escola faz um esforço danado [...] } \\
\text { para cumprir todos os itens a que ela se } \\
\text { propõe. [...] Mas alguns pais vão por } \\
\text { outros caminhos e a coordenação da } \\
\text { reunião não segura muito a onda." } \\
\text { O pai gosta, mas se cansa. Mãe gosta e } \\
\text { "acha inadmissível não ir!"; pai se } \\
\text { incomoda com uma das coordenadoras e } \\
\text { também com as questões pessoais de } \\
\text { outros pais; "(mãe) Eu sempre achei } \\
\text { todas as reuniões muito elucidativas [...] } \\
\text { tinham o objetivo demonstrar como a } \\
\text { rotina ia transcorrer, [...] ajudava mesmo } \\
\text { no acompanhamento ou determinado } \\
\text { entendimento que a gente não estava } \\
\text { sacando [...]". Elas sempre cumpriram o } \\
\text { papel a que se dispunham. O pai gosta } \\
\text { muito de algumas reuniões. Ele próprio } \\
\text { aproveita porque é professor também. }\end{array}$ \\
\hline $\begin{array}{l}\text { Uma modalidade específica de } \\
\text { reunião desta escola }\end{array}$ & $\begin{array}{l}\text { - "Eu fui ao encontro para conversar com } \\
\text { dois professores [...], mas para mim } \\
\text { aquilo foi incrível, porque de cara eu } \\
\text { entrei com uma professora que eu achei } \\
\text { sensacional!". } \\
\text { - Reunião apenas com os professores, } \\
\text { chamada de "plantão de professores", } \\
\text { que convoca os pais para tratar de três } \\
\text { matérias que os alunos estão mal. Cada } \\
\text { pai conversa de dez a quinze minutos }\end{array}$ \\
\hline
\end{tabular}




\begin{tabular}{|c|c|}
\hline & $\begin{array}{l}\text { com cada professor. "E se o aluno não } \\
\text { era chamado, o pai podia dizer que } \\
\text { queria ir, e eu nunca perdi essa chance!". }\end{array}$ \\
\hline Como acompanham o estudo? & $\begin{array}{l}\text { - Não faz lição junto, mas ajuda quando a } \\
\text { filha solicita, principalmente em material } \\
\text { de pesquisa. Pai acompanha também, } \\
\text { não tão de perto porque não moram } \\
\text { juntos, mas ajuda em matemática, além } \\
\text { de ir a eventos. Esta escola não foi } \\
\text { escolhida em comum acordo. } \\
\text { - Não acompanham de perto. A mãe se } \\
\text { dispôs a ler junto com o filho, mas ele não } \\
\text { aceita ajuda. Cobram tarefas, resultados, } \\
\text { controlam. Pai impõe restrições ao futebol } \\
\text { quando as notas não são boas. } \\
\text { Filhos independentes, mas gosta de ver } \\
\text { as provas, tanto para verificar como são } \\
\text { elaboradas como para ver como os filhos } \\
\text { respondem às questões. Pelo pai os } \\
\text { filhos não estariam nesta escola, mas em } \\
\text { outra mais barata. Mas ele vai às } \\
\text { reuniões, acompanha o filho mais velho } \\
\text { em simulados, acompanha o boletim, etc. } \\
\text { Consideram um tema difícil, porque a } \\
\text { escola diz que é para os pais não } \\
\text { ajudarem, mas eles se perguntam "será } \\
\text { que eu devo deixar ele se estrepar?". A } \\
\text { mãe nem sempre segue essa orientação } \\
\text { e, em vários momentos, estuda com o } \\
\text { filho, além da cobrança diária de "fez a } \\
\text { lição?". Acham inclusive incoerente essa } \\
\text { orientação da escola com a prática de } \\
\text { notificar os pais quando o aluno deixa de } \\
\text { fazer três lições. (mãe) "A orientação da } \\
\text { escola é essa (não interferir), mas não } \\
\text { seguimos a orientação da escola. A gente } \\
\text { pegou no pé mesmo!". }\end{array}$ \\
\hline
\end{tabular}

À esquerda dos quadros foram colocadas as pergunta do roteiro comum (aqui foram eliminadas as perguntas de esclarecimentos, feitas durante as entrevistas) e à direita, em cada parágrafo assinalado, as respostas dos entrevistados (cada item é de uma entrevista). Às vezes as respostas foram resumidas, às vezes foi mantida a afirmação literal sem um critério muito definido. Na construção dos quadros, algumas informações específicas foram reorganizadas nas respostas às questões chaves. Ao 
final e em destaque, foram escritos comentários preliminares sobre o que havia em comum em todas elas.

Todo esse trabalho de resumir e, depois, de organizar as respostas exigiu várias leituras do material para destacar frases, expressões e observações importantes dos entrevistados. Dessa forma, a leitura vertical (cada uma das entrevistas) e a leitura horizontal (cada uma das respostas em todas as entrevistas) geraram dois tipos de descrição do material e proporcionaram uma imersão profunda no universo dos dados. Foi algo semelhante ao que Martins e Bicudo (1989) descrevem como o primeiro dos "momentos do método da análise qualitativa do fenômeno situado", em que a "[...] leitura da descrição, entrevista ou relato do princípio ao fim, sem buscar ainda qualquer interpretação do que está exposto ou sem qualquer tentativa de identificar algum atributo ou elemento ali contido. Essa leitura visa a um fim geral de todas as informações" (p. 98).

Só então pode ser feito um levantamento temático desses conteúdos, sem a preocupação de estabelecer uma hierarquia entre eles. Num processo semelhante a um "brain storm" foi-se escrevendo numa folha tudo o que chamava a atenção. Depois, sem acesso a esse material, realizou-se um processo semelhante com mais um dos leitores das entrevistas transcritas (o Professor orientador do presente trabalho). Sem dúvida esse processo é importante para se estabelecer "unidades de significados" (MARTINS E BICUDO, 1989, p. 98) ou "unidades de análise" (LAVILLE \& DIONNE, 1999, p.217), que nem sempre estão "delimitadas com clareza e se encontram misturadas a outros temas" (p.217). Novamente a leitura e a releitura do material foi importante para destacar as ideias comuns aos dois levantamentos $\mathrm{e}$ para definir os temas mais abrangentes e subtemas associados a eles. As unidades temáticas definidas foram:

- As funções educativas dos pais e da escola;

- O acompanhamento e o interesse dos pais pela vida escolar dos filhos;

- As expectativas dos pais em relação à educação escolar;

- As críticas dos pais à escola;

- Reuniões de pais. 
Definidos esses eixos temáticos, estabeleceu-se uma hierarquia entre todas as ideias levantadas no "brain storm", que foram organizadas, então, num plano de escrita. E, como num caleidoscópio em que peças de diferentes cores vão se transformando e configurando novas imagens conforme o movimento do observador, as respostas, as frases, as falas dos entrevistados também foram se reorganizando e se transformando a partir da definição dos recortes temáticos.

Não houve propriamente o estabelecimento de categorias gerais de análise, mas os eixos temáticos possibilitaram perceber convergências e divergências entre os dados, nuances e particularidades de cada um dos eixos, assim como relacionar um tema a outro. Dessa forma foi possível verificar o que era comum e o que era diferente em todos os dados. Às vezes o fato das respostas terem poucos aspectos comuns era justamente o que se tornava o objeto da análise, como poderá ser notado no tópico: O que os pais criticam nas escolas?

Muitas vezes os dados foram comparados com as ideias dos autores consultados, confirmando ou contrapondo seus pontos de vistas, mas sem a preocupação de estabelecer comparações com um modelo teórico único. O trabalho desenvolvido se aproxima do que Laville \& Dionne chamam de "Construção interativa de uma explicação"

O processo de análise e interpretação é aqui fundamentalmente interativo, pois o pesquisador elabora pouco a pouco uma explicação lógica do fenômeno ou da situação estudados, examinando as unidades de sentido, as inter-relações entre essas unidades e entre as categorias em que elas se encontram reunidas. Essa modalidade de análise e de interpretação [...] convém particularmente aos estudos de caráter exploratório (1999 p. 228).

$E$, finalmente, procurou-se relacionar as hipóteses iniciais, com os referenciais teóricos, a metodologia escolhida, os dados obtidos e o trabalho foi concluído. Se o processo de análise consistiu em dividir, dar novas configurações e organizações para os dados, o processo de conclusão procurou sintetizar todas essas ideias, ou seja, reuni-las novamente numa outra perspectiva. De alguma maneira esse trabalho é importante não só para delimitar o alcance e os limites desta pesquisa, mas principalmente para apontar novos caminhos a serem seguidos em trabalhos posteriores. 


\subsection{A importância e os critérios de escolha da escola}

É interessante observar que todos os participantes se mostraram muito interessados e preocupados com a educação escolar dos filhos. Foram criteriosos na escolha das escolas: ou as conheciam (ex-alunos) ou receberam indicações de pessoas em quem confiavam; visitaram-nas antes de fazer a matrícula, assim como conheceram outras escolas, o que é indicativo do alto nível de informações que possuem sobre o sistema de ensino (NOGUEIRA, 1991 e 1995). Além disto, comparecem às reuniões de pais, participam de outros eventos que a escola eventualmente promove, como mostras de trabalhos ou festas e procuram a coordenação quando estão preocupados com alguma questão particular ou quando têm críticas. Nas entrevistas, os pais também se mostraram atentos ao que os filhos estudam, mesmo que muitos não os ajudem diretamente nas tarefas escolares.

Esses dados são coincidentes com o de outras pesquisas (NOGUEIRA, 1991 e 1995; MARQUES, 2002; PAIXÃO, 2007) realizadas com as camadas médias da população. Há uma adesão muito grande dessa camada aos valores, normas e exigências escolares. E essa adesão se dá, segundo Nogueira (1991) e Paixão (2007), por causa da expectativa de ascensão social por meio da escola, o que torna pais e mães verdadeiros "profissionais" em acompanhamento escolar. Segundo Marques (2002), a adesão é decorrente da proximidade cultural entre professores e pais. Seja como for, os pais entrevistados atribuem "[...] à escola um lugar central em seus projetos de futuro, que são construídos a longo prazo, [...] e com esse fim mobilizam amplos recursos (em tempo, energia e meios financeiros) em busca de uma elevada ambição escolar" (NOGUEIRA, 1995, p. 12). Muitos pais e mães relataram seus esforços financeiros para manter os filhos em boas escolas, abrindo mão de bens materiais, como carro, por exemplo, ou solicitando bolsas de estudos e descontos para ter condições de arcar com os custos. Outros ainda moravam distantes da escola escolhida, mas acreditavam que o trabalho operacional valia a pena.

Todos eles também têm sugestões e ideias para que a escola melhore num ou noutro aspecto. Às vezes é apenas um detalhe, como indicar toda a relação de livros a serem lidos no início do ano letivo; às vezes são aspectos mais fundamentais da 
prática pedagógica, como repensar a quantidade e a qualidade de estudos do meio ou aprimorar a sistemática de avaliação dos professores. "É que, quanto maior a capacidade de escolha, maior é a exigência dos pais e a dificuldade de escolher entre os diversos estabelecimentos, porque, em geral, nenhum deles lhes parece ser perfeito" (NOGUEIRA, 1998, p. 44). Como disse uma das mães: "Sou muito crítica [...] não existe a perfeição!". E outro pai: "Não existe escola perfeita!". Esse fato é revelador de que, além de estarem atentos às limitações das instituições de ensino, também são críticos, ou seja, não confiam cegamente nelas, ainda que aceitem seus princípios educacionais mais amplos.

Então, a coincidência de valores parece ser um dos principais critérios de escolha, mais importante até do que a qualidade de ensino em si e uma das razões para os pais se esforçarem em manter os filhos na escola que escolheram, o que também foi verificado em outras pesquisas (NOGUEIRA, 1995 e PAIXÃO, 2007). Segundo Paixão (2007), "as famílias de elite [...] fazem esforço para manter a coerência entre os dois espaços” (p. 28). Assim, na percepção desses pais, há escolas com a mesma qualidade de ensino ou mesmo melhores, mais próximas e mais baratas, mas com uma visão de educação diferente das suas e, por isso, foram descartadas do processo de escolha. Houve também um pai que transferiu a filha para uma escola melhor, em termos de ensino, mas, ao perceber que o público fugia do seu padrão econômico e do seu universo de valores, transferiu-a de volta para a antiga escola que não considerava tão boa, mas cujos valores eram mais próximos dos seus. Mesmo os resultados do ENEM (que serão aprofundados em outro item) não são um fator determinante e, para alguns, são até motivo de críticas.

Aqui também há coincidência com dados de outras pesquisas. Paixão (2007) afirma que a procura por estabelecimentos de ensino privados em que há uma seleção de alunos e permitem controle sobre professores e sobre suas práticas pedagógicas é uma estratégia de socialização da elite. Nogueira (1998) citando pesquisadores ingleses como Ball, Gerwitz e Bowe ${ }^{11}(1994,1995)$ apresentam uma tipologia de

\footnotetext{
${ }^{11}$ BALL, S. (1995). Mercados educacionais, escolha e classe social: o mercado como uma estratégia de classe. Em GENTILLI, P. (coord). Pedagogia da exclusão. Petrópolis: Vozes.
}

BALL, S.; GERWITZ,S.; BOWE, R. (1994). School choice, social class and distinction: the realization of social advantage in education. Londres: Centre for Educacional Studies. King's College. Relatório de pesquisa mimeo. 
pais elaborada a partir dos discursos em torno das escolhas de escolas para seus filhos. De acordo com essa tipologia, os pais entrevistados neste estudo se enquadraram no grupo denominado "privileged/skilled choosers", que se caracteriza por uma valorização do ato de escolher e essa escolha ocupa um lugar central na vida familiar durante longo período de tempo; por possuírem boa capacidade de discriminar os diferentes tipos de escolas e de lidar com várias fontes de informação sem, entretanto, tornarem-se presas fáceis de eventuais propagandas; por procurarem ajustar as características das escolas às características dos filhos, além de levarem em conta um "feeling" baseado no clima geral da escola, constituído pelas atitudes de alunos e professores, pelo discurso dos dirigentes e pela estrutura do prédio.

Além disso, valorizam também a composição social da clientela, pois se importam com quem serão os colegas dos filhos. Como o caso de um casal que optou por uma escola perto de casa, não só pela questão operacional, mas porque os amigos provavelmente também moram perto, o que cria um ambiente mais comunitário. Nas palavras de uma das mães entrevistadas "[...] a gente escolhe escola... A gente vê os pais, tem que ser meio a nossa turma!". E outra: "[...] as famílias que têm seus filhos lá estão mais ou menos próximas da minha condição de vida, tanto pelo poder aquisitivo, quanto pelos valores".

\subsection{Pais culpados e permissivos que delegam todas as funções educativas para a escola: uma generalização indevida}

A partir dos dados obtidos sobre a importância que os pais atribuem à escolaridade e os critérios que usam na escolha da escola dos filhos, pode-se perceber que esse grupo específico de participantes revelou que não delega para a instituição a formação de valores fundamentais de sociabilidade, mas, pelo contrário, busca escolas cujos valores sejam coincidentes com os seus e espera que esse processo de formação se dê de uma forma compartilhada. Um dos participantes disse explicitamente: "A gente não partilha a ideia de que a disciplina se faz na escola, [...] alguma disciplina que eles precisam na vida tem que aprender com a gente, [...] mas a gente não vai delegar para a escola o papel de disciplinar os filhos e não ter controle nenhum sobre eles". Outra afirma: 
[...] a coisa principal é que você tem que ficar focada neles (filhos), tem que ficar preocupada. Você não pode só pagar uma boa escola e deixar seu filho lá dentro achando que está tudo bem, que a escola é ótima, os professores são ótimos, o diretor é ótimo. Não. Acho que a coisa mais fundamental [...] é que você esteja acompanhando, você esteja sabendo como seu filho está se sentindo lá dentro [...] É a parte mais importante e o nosso desafio de pais e mães.

Nesse sentido, o discurso dos pais entrevistados parece mais de acordo com as ideias de Enguita (2004) de que "[...] a velha crítica de que as famílias não se interessam pela educação não faz o menor sentido (como afirmação generalizada)" (p. 69) do que com as de Adorno e Horkheimer (1978) de que "[...] a família cumpre cada vez menos a sua função de instituição de aprendizagem e de educação" ( $p$. 143).

Como foi apresentado no Capítulo 1, seria razoável esperar que as novas configurações familiares, com a mulher inserida no mercado de trabalho, divórcios e novos casamentos, mudança de valores na relação com os filhos (o afeto acima da autoridade) e a predominância de um universo cultural hedonista e individualista, pudessem interferir no papel educacional e na função socializadora da família. Entretanto, não foi o que se verificou nesse grupo específico. Apesar de os participantes apresentarem configurações familiares diferentes (casais; casais formados pelo segundo casamento do pai; mães separadas que moram sozinhas com os filhos; mães que moram com os filhos e um novo companheiro; pai que nunca morou com a mãe da filha e que, atualmente, mora com a filha e a atual esposa), esse fato parece não ter interferido no acompanhamento da escolaridade dos filhos e nem na atenção que dão a eles de uma maneira mais integral (vida afetiva e social).

Esses novos arranjos também não eram vivenciados de forma negativa ou conflituosa, pelo menos não se observou, mas, pelo contrário, eram vividos de forma positiva. Foi o que expressou, por exemplo, uma das entrevistadas ao responder quantos filhos tinha: "A gente é muito juntinho assim... É uma nova família, desse tipo que ex-mulheres e filhas de casamentos diferentes convivem superpróximas, enfim, eu quase sinto [...] que tenho uma filha e meia". 
Muitas vezes esses novos arranjos familiares até contribuíram para melhorar o desempenho escolar dos filhos, como é o caso do pai que trouxe a filha para morar com ele porque na casa da mãe não tinha ninguém que a ajudasse nas lições e de pais que, depois que se separaram, passaram a frequentar mais as reuniões na escola para poderem ter mais informações sobre ela e sobre os filhos. Há também o casal, formado pelo segundo casamento do pai, que organizou a vida profissional de forma que possa levar e buscar os filhos na escola e também realizar todas as refeições juntos. Nesse sentido, as famílias dos entrevistados se aproximam mais das caracterizações de Ferry (2008) e Roudinesco (2003) do que Adorno (1978), Hobsbawm (1996) e Donatelli (2004). A família "[...] é, inclusive, uma das raras instituições - a única? - a ter, de um modo ou de outro, perdurado após a Revolução, a ponto de se manter hoje mais viva e, paradoxalmente, apesar do elevado número de divórcios, mais estável do que nunca" (FERRY, 2008, p. 78).

É importante ressaltar que não foram todos os pais contatados que aceitaram ser entrevistados - alguns não autorizaram sequer que a direção fornecesse o número de seus telefones; outros disseram, por intermédio da escola, que não queriam ou não podiam dar entrevistas; outros ainda, ao serem informados dos objetivos da pesquisa, disseram que não tinham disponibilidade para tal. E esse pode ter sido um viés particular na seleção dos participantes, pois, de alguma forma, apenas pais que sentem afinidade com o tema ou que estão mais preocupados e atentos à escolaridade e ao desenvolvimento dos filhos aceitaram conversar. Aqueles com tendência a delegar tarefas para a escola e apenas cobrar dela eficiência talvez não tenham manifestado interesse em colaborar com a pesquisa. Mas essa é apenas uma hipótese que não foi possível comprovar.

De qualquer maneira, é importante destacar que qualquer afirmação de que a família vive uma crise de valores e de autoridade e por isso não transmite valores fundamentais de sociabilidade, delegando essa tarefa para a escola, é uma generalização indevida e pode estar carregada de preconceitos. Também não se pode dizer que isso não aconteça de forma alguma e que essa percepção por parte das instituições escolares é equivocada. Parece mais correto afirmar, a partir dos dados da nossa amostra, que há famílias que fazem questão de participar e só não participam mais porque não encontram espaço para isso na própria organização escolar, como observa uma das entrevistadas: "[...] os pais hoje em dia acham que a 
escola tem a obrigação de educar os filhos [...]. Em contrapartida, o colégio permite que os pais tenham esse pensamento justamente por não promover tanto essa integração".

Dado que coincide com o estudo de Bhering e Siraj-Blatchford, em que pais manifestam interesse em se envolverem mais com a escola e "querem acesso maior à informação, um diálogo mais aberto com os professores e uma confiança maior naquilo que a escola faz [...]" (1999, p. 202); com as conclusões da pesquisa de Gasonato (2007) em que as famílias buscam diálogo e a participação na escola dos filhos; e também com o próprio levantamento do governo federal na "Pesquisa nacional da educação: a escola pública na opinião dos pais: resumo técnico executivo": "A pesquisa apontou para um desejo dos pais ou responsáveis em intensificar a relação família-escola" (PACHECO; ARAÚJO, 2005, p.19).

Também se verificou que todos os participantes disseram ter uma vida profissional bastante intensa. É difícil dizer exatamente o quanto trabalham, até porque não lhes foi perguntado objetivamente, mas alguns revelaram que viajam frequentemente, outros que chegam cansados à noite em casa e sem disposição para acompanhar de perto o estudo dos filhos, e com outros ainda foi difícil encontrar um horário para a entrevista, mesmo no período da noite ou fim de semana. O que se pode concluir é que, nesta amostra, havia pais e mães ausentes de casa na maior parte do tempo, dedicados a seus trabalhos, e, por isso, relativamente bem-sucedidos profissionalmente. Um pai expõe essa situação claramente: "Nós somos ausentes em casa e só fica a empregada [...], que não foi contratada para ficar monitorando meus filhos".

Segundo Donatelli (2004) a ausência dos pais na maior parte do cotidiano dos filhos é um ingrediente importante para alimentar um sentimento de culpa desmedido nos pais, responsável por gerar compensações materiais e uma dificuldade em dizer não para desejos desmesurados e fora de propósito dos filhos. "E os pais, sentindo-se culpados por tudo o que deu errado e, principalmente, por aquilo que possa vir a dar, compensam a situação consumindo grande parte do que a indústria cultural e de quinquilharias produz". (p. 69). Contudo, a tendência de se sentirem culpados por trabalharem na maior parte do tempo e não se dedicarem exclusivamente aos filhos também não foi constatada nos pais e nas mães do grupo pesquisado. Ao contrário, 
muitos dos entrevistados, principalmente as mães que vivem sozinhas com os filhos, relataram que, apesar de não terem como conferir detalhadamente as tarefas escolares dos filhos, encontram tempo e/ou maneiras de supervisionar o que estão fazendo em casa, seja "monitorando pelo telefone" ou criando espaços na rotina, "tem que ter um tempo, tem que se disponibilizar, [...] no café da manhã, no almoço e no jantar".

Os entrevistados falaram com tranquilidade - sem demonstrar culpa ou dúvida das limitações que impunham aos filhos caso não cumprissem as obrigações escolares ou se comportassem em desacordo com as regras e valores estipulados por eles. Ficar sem TV e internet, deixar de jogar futebol e deixar de frequentar a casa de amigos foram alguns exemplos dados. A ideia de Donatelli de que atualmente nas famílias burguesas "A coação e a força da autoridade [...] se esvai em afetividade. E somente em afetividade" (2004, p.30) não prevaleceu nesse grupo. Os pais não só consideram importante exercer a autoridade perante os filhos, impondo regras claras para eles, como alguns até julgam as escolas permissivas demais em certos momentos. Tal foi o caso do pai que queria impor o uso uniforme, mas foi voto vencido, e da mãe que ficou indignada porque os alunos jogavam mochilas pela escada e a escola não tomava nenhuma providência. Houve ainda o casal que mudou a filha de escola porque julgou que lá havia uma dificuldade em dizer às crianças "agora chega”!

Talvez nossos entrevistados tenham uma visão de autoridade, como pais, mais próxima da descrita por Paulo Freire (1996) para os professores, quando disse que sua autoridade "se expressa na firmeza com que atua, decide, com que respeita as liberdades, com que discute suas próprias posições, com que aceita rever-se" ( $p$. 102), o que também parece ser uma característica dessa camada social pesquisada, coincidente com dados de outras pesquisas:

A aprendizagem de normas sociais, também consideradas como parte do trabalho da escola, apresenta-se menos como imposição e mais como decorrência de discussão. O estilo de educação dessas camadas é marcado por orientação de tipo contratual em que a imposição deve ser afastada e a motivação, a autonomia do indivíduo e sua criatividade são estimuladas (PAIXÃO, 2007, p. 34). 
A "guerra surda" entre família-escola, assim nomeada por Donatelli (2004) em função de a escola submeter crianças e jovens a regras e valores, não foi identificada. Nesse aspecto o que se verificou, a partir dos discursos dos entrevistados, aproxima-se mais da "harmonia vigiada" nomeada por Paixão (2007):

[...] os valores que orientam o trabalho escolar não se distanciam daqueles considerados por eles como adequados. As camadas médias avaliam que há proximidade entre os valores que conduzem a socialização na família e na escola. Entretanto, permanecem vigilantes e procuram intervir para evitar dissonâncias indesejáveis entre as duas instâncias (p. 44).

Houve um casal, por exemplo, que passou a perceber que outros pais têm uma visão bastante utilitária, elitista e classista, vendo a escola como "um lugar onde as filhas vão encontrar maridos ricos e os filhos encontrar bons parceiros de negócios". Assim, consideram que devem ficar bastante atentos a isso, observando se sua filha está absorvendo esses valores.

Há, sim, descontentamentos, críticas e até desconfianças em relação à escola, questões que serão desenvolvidas posteriormente, mas não pelo fato de ela estabelecer regras de convivência e impor sanções caso não sejam cumpridas. Sempre que as escolas puniram ou advertiram os alunos por contrariarem algumas dessas normas, as famílias as apoiaram. Uma mãe, inclusive, observa que a filha se queixa de que para ela "os professores sempre estão certos", e também outro casal relata que são acusados pelos filhos de sempre darem razão à escola. Num único caso em que o aluno foi proibido de jogar futebol, o pai achou que houve exagero por parte da escola. E foram citados muitos outros, como o de ir de sandália, romper uma norma de segurança, envolver-se em brigas físicas, etc. Um casal até afirmou que gosta de ir à escola conversar sobre problemas de comportamento do filho: "sempre (coordenadores) estavam certos [...], e a abordagem deles sempre foi muito positiva, [...] nunca encaramos como uma maneira de confronto, sempre achamos bom".

Também para Donatelli (2004), nas famílias atuais 
A ausência de papéis claramente definidos entre homens e mulheres permite que o vazio moral seja um adjunto na confusão vivida dentro de casa. Uma existência voltada para o acúmulo material, antes de ser uma vida para a construção de um legado, torna-se um dever enfadonho de juntar coisas, e não de agregar sujeitos (p. 79).

Mais uma vez esse aspecto não foi o identificado nas famílias entrevistadas. O que se observou, nas conversas com casais, é que pai e mãe são cúmplices na escolha da escola e nas preocupações com o desenvolvimento e com a aprendizagem dos filhos, ou seja, partilham os mesmos ideais educacionais e possuem expectativas semelhantes. E, embora seja a mãe que acompanhe e cobre mais as tarefas do diaa-dia escolar - outro dado coincidente com o de outras pesquisas como de Ribeiro (2000), Bhering e Siraj-Blatchford (1999), Marques (2002), Nogueira (1995 e 1991) -, há uma reflexão conjunta a respeito da educação de uma maneira mais ampla e, em momentos críticos como dificuldades de aprendizagem, problemas com professores ou de relacionamento, os pais comparecem à escola para conversar e fazem intervenções nas atitudes dos filhos. Não se identificou uma divisão de papéis, mas um "fazer junto". São casais que parecem não se voltar apenas para o acúmulo material, mas que sentem prazer em educar os filhos.

Vale lembrar que em apenas um casal o pai não participou da conversa e que a mãe admitiu que a questão da escolaridade fica "totalmente com ela" e que ele também nunca interferiu na escolha da escola e "só cobra o boletim". Já nas conversas com as mães separadas, encontrou-se mais desacordos em relação à questão do acompanhamento da escolaridade dos filhos. Em alguns casos a escolha da escola foi apenas da mãe; em outros a escolha se deu antes da separação e, portanto, foi de comum acordo. Duas afirmaram que os ex-maridos valorizam menos a educação que elas e, portanto, transfeririam os filhos para escolas mais baratas ou públicas diante de eventuais dificuldades financeiras. Mas, mesmo assim, todas admitem que eles não são indiferentes à vida escolar, porque cobram o boletim, comparecem às reuniões, eventos e apresentações de trabalhos.

Outra característica das famílias burguesas contemporâneas descritas por Donatelli (2004) é o amor incondicional aos filhos. Esse fenômeno, relativamente recente, misturado ao sentimento de culpa pela ausência cotidiana, faz com os pais mimem e superprotejam os filhos. Não os educam; pelo contrário, com mimos e a 
superproteção tornam-se reféns das vontades e idiossincrasias dos filhos. Nas suas próprias palavras:

\begin{abstract}
Por razões que ainda não me parecem claras, migramos de uma situação de indiferença para com as crianças para o extremo oposto. Em um pouco mais de dois séculos e meio criou-se em volta da criança um lastro de amor desmedido. Isso implicou em uma superestimação da vida privada e uma dependência da criança em relação aos pais. [...] A pequena burguesia, culpada e desejosa de ascensão, projeta nos filhos todas as suas expectativas e necessidades. Os filhos estão sempre em primeiro lugar, nada se pode fazer sem antes considerá-los (p.68 e 69).
\end{abstract}

Porém, na verdade, o que foi verificado neste grupo, foram pais e mães com expectativas adequadas em relação aos filhos. Todo o esforço para escolher e para mantê-los em escolas de qualidade revela o desejo de que sejam bem-sucedidos profissionalmente e felizes na vida adulta, o que também tem se mostrado como uma característica dessa camada social com um grande capital cultural (NOGUEIRA, 1995 e 1991 e PAIXÃO, 2007). Alguns verbalizaram isso explicitamente "(a escola) é melhor do que eu esperava, as crianças vão ter condições de escolher a carreira que quiserem ter". E outros não escondem o amor, o orgulho e admiração pelos filhos: "Nós somos, lógico, todo pai é babão... Mas nosso filho ajuda a gente, ele é boa pessoa!". Expressões que confirmam o que diz Ferry (2008):

Como nunca, os pais amam seus filhos, ficam paralisados de angústia diante da ideia de que o futuro possa não deixar que se "realizem" e curiosamente, na maioria das vezes, os filhos lhes devolvem o mesmo amor. $E$, também incessantemente, esse laço se reforça e se aprofunda ( $p$. 78).

Entretanto, apesar de amarem os filhos e se orgulharem das qualidades deles, esses pais e mães pesquisados não parecem mimá-los demais, assim como não parece que se colocaram como reféns desse afeto. Um exemplo disso é o relato da mãe cuja filha queria mudar de escola para ampliar seu círculo de amizades e ela não concordou. Manteve-a na escola que considerava boa e matriculou-a numa atividade esportiva, ou seja, entendeu que a questão de fazer novos amigos era 
importante para a garota no início da adolescência, mas não abriu mão dos seus próprios princípios em função dos desejos dela. Outro exemplo é o dos pais que, quando o filho propôs mudar-se para outra escola que avaliavam semelhante à dele, não concordaram e propuseram que o jovem conhecesse outra forma de ensino, o técnico. Assim ele pôde reconhecer que, de fato, gostava da escola em que estava. São encaminhamentos que mostram que esses pais estão atentos às solicitações dos filhos, mas diferenciam "o embalo" da vontade própria. Portanto, a ideia de "adultos acuados [...] que se rendem a um plano de concessão e oferecimento desmesurado [...]" (DONATELLI, 2004, p, 127) também não se fez presente nesse grupo de pais participantes.

Mas é importante destacar que essas contraposições ao pensamento de Donatelli (2004) não indicam que suas percepções e hipóteses estejam absolutamente equivocadas. Apenas se está afirmando que amplas generalizações sobre aspectos do comportamento de famílias das camadas médias e de elite podem ser inadequadas. Se se parar para pensar, qualquer um de nós conhece uma família que, de alguma maneira e num ou noutro aspecto, reproduz o que ele descreve. Os próprios entrevistados criticaram outros pais que não sabem dizer não aos filhos, supervalorizando-os. Como diz um deles, "os pais estão educando os filhos para serem príncipes e princesas [...] e não os prepara para serem cidadãos, para serem mais colaborativos, para serem mais um que pensa [...] e que entende essa coisa do grupo". E outro pai, referindo-se a um casal conhecido, disse que tratam o filho "como o imperador da casa [...] e a mãe e o pai acabam sendo serviçais do garoto".

As críticas ácidas e contundentes de Donatelli (2004) podem servir de alerta a todos que os estão inseridos numa sociedade capitalista, pautada pelo consumo, pela aquisição de bens materiais e que buscam a felicidade por meio do amor romântico. Entretanto, numa mesma camada social (média e média alta), nem todos pensam e se comportam de maneira uniforme, como se dá a entender não só no texto de Donatelli, mas no de muitos outros autores que, sem uma base empírica sólida para apoiar suas conclusões, são pouco cautelosos em suas generalizações, simplificando demais fenômenos sócio-psicológicos complexos, como é o caso da visão que os pais têm sobre a educação escolar dos filhos. 


\subsection{O acompanhamento da vida escolar pelos pais nem sempre leva ao sucesso acadêmico}

Vários estudos têm sugerido que o acompanhamento da vida escolar dos filhos é um fator importante para o sucesso acadêmico de crianças e jovens (PINHEIRO, 2007; POLONIA; DESSEN, 2005; PEREZ, 2004; CHECHIA, 2002; MARQUES, 2002; FRAIMAN, 1997). Na amostra pesquisada tal afirmação parece ter sido corroborada. Do conjunto de todos os filhos dos entrevistados (28 crianças e jovens e não apenas os que foram sorteados), apenas três foram caracterizados como maus alunos, sendo dois com histórico de reprovação. Todos os outros foram descritos pelos pais como regulares, bons e excelentes alunos. Contudo, o interesse demonstrado é mais pelo que estão aprendendo do que o hábito de estudarem juntos. Praticamente a maioria dos entrevistados disse que não estuda junto com os filhos, mas apenas os ajudam quando eles solicitam. Uma mãe diz: "Acompanho, cobro, mas não sento para fazer lição [...]. Por um lado porque eu não tenho muita paciência; por outro, eu acho que não é minha obrigação". Outro casal: "A gente acompanha mais o processo de mudança no nível psicológico [...]. Em relação ao conhecimento a gente não acompanha tanto". Só duas mães, cujos filhos apresentam dificuldades na escola, afirmaram que muitas vezes fazem as tarefas com eles.

Por outro lado, o que esses casos de estudantes com dificuldades de aprendizagem sugerem é que não é apenas o acompanhamento dos pais e o fato de pertencerem às camadas médias e altas da população que determina o bom aproveitamento escolar, dado que também é coincidente com o de outras pesquisas sobre 0 assunto. Nogueira (2004), ao se referir a um estudo realizado pelo econometrista francês Jean Fourastié ${ }^{12}(1970$ e 1972), do Conservatoire National dês Arts et Métiers (CNAM), com um conjunto de famílias pertencentes a categorias socioprofissionais superiores, diz:

\footnotetext{
${ }^{12}$ FOURASTIÉ, J. (1972). Enquête sur la scolarité d'enfants appartenant à milieux favorisés. Analyse et Prévision, $\mathrm{n}^{\circ}$ 1-2. Juil-août.
} (1970). Une enquête sur la scolarité d'enafants d'instituteurs et normaliens. Em Institut Nacional d'Études Démografiques (INED). Population et enseignement. Paris: PUF, p. 532538. 
Seus resultados demonstraram que, embora essas categorias sociais apresentem taxas de sucesso escolar acima da média da população, elas não estão imunes ao fracasso escolar, pois uma porcentagem considerável dos filhos dos pesquisados (30\%, em média) não teve acesso, na época, ao ensino superior (p. 133 e 134).

É importante que educadores tenham clareza de que nem sempre alunos com resultados insatisfatórios têm famílias ausentes, desinteressadas e que não apóiam as ações das escolas. Em nossa amostra esses pais (especialmente as mães), mais do que simplesmente cobrar as tarefas, muitas vezes se dispuseram a estudar junto com os filhos, compareciam à escola frequentemente para conversar e procuravam, por sugestão da escola, outros profissionais, como fonoaudiólogos, psicólogos, neurologistas, psicopedagogos e professores particulares para ajudar os filhos a terem um bom desempenho. Tudo isso porque entendiam que as dificuldades apresentadas pelos filhos eram decorrentes de problemas ou características deles e não do ensino, até porque tinham outros filhos com bom desempenho na mesma escola, o que também é coincidente com outros estudos realizados também na França por Robert Ballion (1977) ${ }^{13}$ e citados por Nogueira (2004)

[...] as posses econômicas conseguem reparar, em boa parte, os prejuízos dos atrasos e dos acidentes ocorridos no percurso escolar. Isso porque essas famílias dispõem de meios de luta contra o insucesso escolar, através de estratégias variadas de compensação e de reparação, capazes de remediar ou, ao menos, de atenuar os efeitos nefastos do fracasso (p. 134).

A forma como esses problemas de aprendizagem são encaminhados pelas escolas merece atenção: elas não consideram a possibilidade de que possam estar relacionados ao seu método de ensino ou a sua própria estrutura, mas que acontecem por fatores externos a ela. Isso não significa afirmar que a dificuldade de aprendizagem não possa estar de fato associada a um problema médico ou psicológico, mas, avaliando-se a experiência dessas famílias que puderam contar com apoio de diversos profissionais, verificou-se que o desempenho escolar desses alunos não mudou significativamente, mesmo com o acompanhamento de vários profissionais, às vezes até simultaneamente.

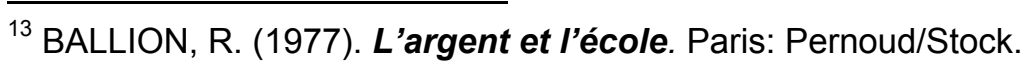


Num desses casos, diagnosticado como déficit de atenção e hiperatividade, o aluno passou a tomar medicamentos e, ainda assim, não melhorou o rendimento. Também há o depoimento de outro pai, que contratou vários profissionais de apoio para ajudar o filho e avaliou: "O problema continua [...], ele tem um problema de atenção, se dispersa facilmente. Para mantê-lo nesta escola tive que pagar outra escola [...] Agora ele teve alta da psicopedagoga".

Esses fatos corroboram as ideias de Lash (1991) e Costa (2004) sobre como as famílias, principalmente das camadas médias e altas, recorrem à ajuda de especialistas de todos os tipos para resolver seus problemas internos. Exemplo característico é a figura do "tutor", descrita por um dos casais entrevistados: é uma pessoa, remunerada pela família, que vai até a casa do aluno estudar com ele e ajudá-lo em aspectos da organização. "Ela (a tutora) sabia todas as matérias, também organizava e limpava o quarto, arrumava a mesa, coisa que a psicopedagoga não ensinava. Punha os horários, os compromissos e o que devia fazer a cada dia para não deixar tudo para a última hora", disse a mãe.

Como diz Patto (1997) e Perrenoud (2001) o fracasso escolar é um produto de múltiplos fatores, incluindo o funcionamento e o currículo da própria instituição escolar. A tendência de as escolas considerarem a questão da dificuldade de aprendizagem como exterior a elas é, quase sempre, uma explicação simplista que pode encobrir eventuais falhas nas suas práticas pedagógicas. Vários estudos vêm apontando isso (GASONATO, 2007; CAETANO, 2005; GOMES 1997; PATTO 1997). Essa tendência não está presente só nas escolas públicas, mas também em estabelecimentos particulares de ensino, como é o caso desta amostra. Assim, as escolas terceirizam o problema, fazendo com que os pais recorram a um arsenal de especialistas, sem considerar que as dificuldades podem estar relacionadas ao seu método de ensino e/ou a sua sistemática de avaliação e/ou à resistência em mudar alguns de seus procedimentos padrões.

Uma das mães entrevistadas vivenciou essa situação com o filho que teve muita dificuldade para se alfabetizar em função de problemas emocionais que teve na primeira infância. Depois de buscar muitos especialistas, decidiu mudá-lo para uma escola com outro método de ensino, e todas as dificuldades desapareceram. "Eu achava que meu filho tinha algum problema pedagógico [...] ainda coloquei em 
psicopedagoga, Kumon [...]. No terceiro ano ele ainda não estava alfabetizado [...] e foi quando eu conheci a pedagogia Waldorf que mostrou outro universo para mim [...]". Nessa escola, menos pressionado, segundo a mãe, não se tornou um excelente aluno, mas passou a acompanhar a turma. Mesmo na escola atual, que não segue a pedagogia Waldorf, ele não tem sérios problemas de aproveitamento. Nas palavras de outra mãe, "A escola é um bonde andando. Se alguém cai, vai ter que correr atrás para subir, pois ela não vai parar para a pessoa subir".

Na nossa amostra, uma única família relatou um desacordo que teve com a maneira de agir da escola do filho, que foi reprovado, e optou por transferi-lo para outra escola. Os pais alegaram que não foi pela reprovação em si, mas porque o filho passou a ser estigmatizado pelos professores e pela orientadora, diminuindo suas possibilidades de melhora. Além disso, eles se decepcionaram com o fato de, naquela escola, nunca terem sugerido que investigassem melhor as origens das dificuldades do filho, "rotulando-o de preguiçoso". Por iniciativa própria vieram a descobrir que ele tem déficit de atenção e hiperatividade. Esse caso ilustra outra tendência das escolas e dos educadores: a de reduzir a dificuldade cognitiva a um problema moral e de comportamento, o que também foi verificado em outras pesquisas (GARCIA, 2005). O pai, nesse caso, sentia que, "na forma de colocar, transferiam o problema", e a mãe complementou dizendo que, depois de algumas reuniões, ela saía "chorando, porque meu filho não ia ter jeito! [...]. Eles não apontavam soluções! Felizmente encontramos outra postura nos coordenadores da escola atual com a qual a gente se identifica! [...] A mensagem é mais direta, ajuda lá que eu ajudo aqui!". Disseram que na escola atual é feita uma análise mais ampla dos resultados do filho, além de adotarem uma postura mais colaborativa.

De um modo geral, os pais, por confiarem nas instituições que escolheram, não questionam as sugestões de procurarem especialistas - até as elogiam, como a mãe que se mostrou muito satisfeita com a escola que sempre teve muita paciência para lidar com seu filho "fora da distribuição da curva normal" - e as seguem integralmente, apesar do alto custo financeiro e emocional que representam, pois o insucesso dos filhos na escola gera sofrimento também aos pais. "Já sofri muito com esse problema", diz uma das mães. E o pai retifica, dizendo que continuam sofrendo, "pois o problema não se resolveu". 


\section{5. $O$ interesse dos pais acompanha toda a vida escolar}

É comum pensar que o interesse e a participação dos pais pela vida escolar dos filhos vão diminuindo à medida que eles crescem e conquistam mais autonomia e independência. Por isso, decidiu-se conversar com pais cujos filhos estivessem no Ensino Fundamental II, ciclo em que aconteceria essa transição de um acompanhamento mais sistemático para outro mais esporádico. Mas, por questões práticas já descritas no Capítulo 2, os entrevistados foram pais de alunos do Ensino Médio, do Ensino Fundamental I e da Educação Infantil também. E o que se pôde constatar é que o interesse dos pais pela escolaridade dos filhos se mantém durante toda a vida escolar deles, ou seja, não diminui à medida que os filhos crescem.

Os pais não deixam de comparecer às reuniões de pais, por exemplo, nem de procurar a escola quando alguma coisa os preocupa, nem de cobrar dos filhos as obrigações com o estudo. A única coisa que diminui, segundo alguns, é a participação em eventos sociais, como festas juninas, por exemplo, até porque até os próprios filhos perdem um pouco o interesse pelos eventos ou porque vão para ficar com os amigos. Especialmente numa das escolas em que o grupo de pais entrevistados da $3^{\mathrm{a}}$ série do Ensino Médio foi maior, todos eles relataram com detalhes os problemas que a turma viveu com uma das professoras, a atitude que a escola teve e como eles próprios a procuraram para discordar do encaminhamento dado. Em outra, uma das mães, cujo filho está na $2^{\mathrm{a}}$ série do Ensino Médio, para poder acompanhar melhor o trabalho de pesquisa que ele deveria fazer, praticamente exigiu outra reunião de pais para conhecer pessoalmente o professor que orientaria o trabalho do filho.

Há até o caso de uma mãe que se queixou de que a filha, que agora está no Ensino Fundamental II, não solicita tanto sua ajuda nem quer mostrar o que tem feito: "Está muito difícil de pegar [...] ela está nos excluindo [...] não é que a gente precisa acompanhar [...] é porque a gente quer acompanhar mesmo, acha legal!" Teve ainda a história de um casal que decididamente não segue a orientação da escola que é de não interferir nas tarefas e nos trabalhos. O pai até fica em dúvida: "Deixo o cara se estrepar?" Mas com a mãe não tem erro: "nós não seguimos a orientação da escola, a gente pega no pé mesmo!" Posturas como essas comprovam a hipótese 
de Nogueira (1995) de que "[...] são as frações mais equipadas em capital cultural as mais aptas a responder com maior eficácia às exigências da escola (e até mesmo a antecipá-las, o que é muito frequente)" (p. 15).

É evidente que a forma de acompanhar o filho e as preocupações relativas à escola mudam, o que só reforça que o interesse dos pais na vida escolar dos filhos se mantém. No início da escolaridade, muitos afirmaram que se preocuparam com o processo de alfabetização, por exemplo. Uma das mães, que achava que a filha escrevia com muitos erros ortográficos, disse: "A escola me orientou bem: disse que eram normais os erros, tanto que hoje ela escreve bem”. Já no Ensino Fundamental II, as questões levantadas se relacionaram mais aos hábitos de estudo. Uma das mães relatou que a escola não exigia muito estudo em casa, o que era, no seu ponto de vista, uma falha, mas que agora ela está satisfeita porque percebe que a própria escola se tornou mais exigente. Outra mãe imaginava que a mudança de escola e a entrada no Ensino Fundamental II fariam com que o filho dedicasse mais tempo e tivesse mais disciplina com o estudo, o que não se verificou: "Continua igual, faz em cinco minutos [...]". Ao procurar a escola, o diretor lhe disse que o aluno já passava mais de cinco horas na escola e que não precisava estudar muito mais tempo em casa. Apesar dessa resposta, a mãe continua apreensiva quanto à disciplina do filho para o estudo. Esses exemplos só reforçam a importância que essa camada da população atribui à educação escolar e ao estudo dos filhos. Nesses dois casos, embora os filhos estudem em boas escolas, os pais acabam sendo mais exigentes em relação ao estudo do que elas próprias.

Depois, no Ensino Médio, o universo de preocupações passa por escolha profissional, vestibular e drogas. Da mesma maneira, os pais esperam encontrar na escola interlocução e orientação para ajudarem os filhos a lidar com essas questões. O trabalho de orientação profissional de duas escolas (segunda e terceira) foi especialmente elogiado por muitos pais. Não que seus filhos já estejam certos do que vão fazer, mas reconheceram que a escola está oferecendo oportunidades para eles refletirem. Já o vestibular é mais polêmico. Enquanto alguns pais expressaram tranquilidade com a possibilidade de o filho ter de se preparar em cursinhos para entrar na universidade, outros disseram que seria bom que a escola já os preparasse para terem condições de seguir qualquer carreira, inclusive as mais disputadas. O depoimento de uma das mães: "Quando eles eram pequenos, eu 
achava bacana a escola não se voltar para o vestibular.[...] Vestibular, basta treinar! [...] Mas, à medida que os anos foram passando, não sei... É mais uma ansiedade minha!" , ilustra bem o que acontece com os pais quando os filhos se aproximam dessa fase. Afinal, o vestibular é, de certa forma, a concretização de muitas das expectativas depositadas na educação escolar relativas à ascensão social.

As drogas também são motivo de muita apreensão. Numa das escolas, a condução de um caso de alunos que estavam fazendo uso de drogas dentro da escola foi muito elogiada por um dos pais e até aumentou sua confiança na instituição. “Trataram com objetividade, não se buscou uma coisa de segregar!". Já nas outras duas escolas, a posição é mais dura: "Não aceito, não admito. Se pegar, está fora da escola!", além de informarem aos pais quando eventualmente desconfiam de alunos que estejam fazendo uso de drogas fora da escola. E os pais estão de acordo com esses encaminhamentos.

Entretanto, expressam, de um jeito ou de outro, que talvez isso não seja suficiente: "Esse assunto precisa ser mais explorado! A escola fez um trabalho muito bacana com os alunos, com a comunidade escolar, passaram questionário [...], chamavam as famílias quando percebiam que o aluno fazia uso, [...] mas apesar de tudo isso e da repressão, acho que ainda acontece, escapa!" E ainda "[...] apesar da vontade, das tentativas de fazer uma avaliação, parece que isso continua sendo uma coisa difícil, [...] não tem uma coisa nítida a esse respeito". É possível observar que esses pais não estão cobrando exatamente que as escolas cuidem do problema das drogas, mas de alguma maneira esperam que ele seja mais trabalhado, tanto com os alunos como com os pais.

\subsection{Afinal o que os pais esperam da escola?}

Como já foi abordado no item 3.2, os pais esperam encontrar nas escolas, e é até um dos principais critérios de escolha, a continuidade dos seus próprios valores e princípios educativos: "É um prolongamento muito direto da casa". Esperam isso não só da escola em si, mas de toda a comunidade escolar. Se "não forem famílias que mais ou menos tenham uma aproximação com seus valores, com suas ideias, com seu jeito de inserção na sociedade, no mundo, fica difícil!", o que corrobora os 
resultados de outros pesquisadores (NOGUEIRA, 1991 e 1995; MARQUES, 2002; PAIXÃO, 2007). Não raro algumas famílias acabam se tornando amigas por causa da amizade dos filhos e também pela convivência que têm também na escola. Uma das entrevistadas relata que a escolha da escola atual foi feita em comum acordo com um grupo de pais que se conheceram na escola de Educação Infantil e queriam que os filhos continuassem juntos.

Mas, em relação ao ensino, o que se pode destacar como comum a todos os participantes é que esperam que os filhos tenham prazer em aprender, a curiosidade aguçada, uma formação ampla em todas as áreas do conhecimento, inclusive nas artes e nos esportes, mas que, sobretudo, desenvolvam um pensamento crítico. "Preparar o aluno para ele pegar uma informação e ser capaz de fazer uma análise crítica da informação, ser capaz de estudar a informação!" São pais, portanto, que valorizam aspectos mais amplos da formação e do desenvolvimento das crianças e jovens e atribuem à cultura e ao conhecimento uma importância própria e não os veem como algo utilitário que deva servir para o futuro profissional dos filhos. Houve, inclusive, um casal que criticou as escolas que adotam essa postura utilitária desde a Educação Infantil, o que o levou a escolher uma "[...] que não preparava para nada, só acolhiam a criança, deixavam brincar e a ficar com as outras crianças". Mesmo os pais cujos filhos estudavam numa escola técnica demonstraram mais preocupação com aspectos integrais da formação do que com a preparação técnica para o exercício da profissão. Apenas um dos pais fazia mesmo questão de que a filha saísse do Ensino Médio já com uma profissão, pautado na sua própria experiência pessoal. Esta pesquisa mostrou mais uma característica dessa camada social, com alto capital cultural, confirmada em outras pesquisas (NOGUEIRA, 1991 e 1995; PAIXÃO, 2007).

Em função disso, os pais demonstraram que são críticos à supervalorização dos resultados do ENEM feita por alguns veículos de informação. Para eles, além de acirrar a concorrência entre as escolas, fazendo com que algumas delas se voltem demais para o marketing (TVs de LCD, viagens para acampamentos caros), e também leva a algumas modificações nem sempre positivas nas suas práticas pedagógicas. Na opinião de um pai: "Por causa do ENEM, o que aconteceu é um excesso de estudo, muita matéria!". E a mãe complementa: "As escolas estão neurotizando as crianças [...] vale a pena isso?". Pode-se concluir que, para esse 
grupo de pais que foram entrevistados, os resultados do ENEM não só não foram levados em conta na escolha da escola, como não interferem significativamente na avaliação que fazem do seu trabalho pedagógico. "Até que saiu melhor do que eu esperava." - é o comentário de um pai cujos filhos estão numa escola que obteve bons resultados no ENEM. "Aquele índice da revista eu acho a coisa mais furada do mundo!", disse uma mãe cujo filho está numa escola que não teve bons resultados no ENEM.

Nogueira (1998), relatando o estudo dos pesquisadores ingleses Ball, Gerwitz e Bowe $(1994,1995)^{14}$, observa que há dentro desse grupo dos "privileged/skilled choosers" uma pequena distinção entre os pais "objective/goal oriented" e os "subjective/ person oriented", ou seja, os que orientam a escolha da escola mais por dados objetivos, como aprovação dos alunos em exames, concursos e rankings, e os que priorizam a capacidade da escola em desenvolver múltiplas potencialidades nos educandos. Por meio das opiniões que os pais entrevistados emitiram sobre os resultados do ENEM e dos rankings divulgados pela imprensa, pode-se concluir que eles estão mais próximos do segundo subgrupo.

Os pais também esperam que a escola promova uma boa interação entre os alunos, de forma que possam ter uma boa convivência, desenvolver amizades sólidas e ter prazer em ir para a escola. Nesse sentido todas as escolas parecem fazer um bom trabalho, pois os pais se mostraram muito satisfeitos. Numa delas o pai disse: "Eles não vão para a escola estudar; eles vão encontrar os amigos!". E em outra, a mãe conta que o filho não quis fazer um intercâmbio para não se afastar alguns meses da escola, dizendo: "É muito gostoso!". Por outro lado, os pais também julgam importante que haja, no ambiente escolar, a maior diversidade possível. Na escola que fica na região central, perto do metrô, o fato de ser frequentada por pessoas que moram em diferentes regiões da cidade, pertencentes a "diversas tribos", é visto como muito positivo.

\footnotetext{
${ }^{14}$ BALL, S. (1995). Mercados educacionais, escolha e classe social: o mercado como uma estratégia de classe. Em GENTILLI, P. (coord). Pedagogia da exclusão. Petrópolis: Vozes.
}

BALL, S.; GERWITZ,S.; BOWE, R. (1994). School choice, social class and distinction: the realization of social advantage in education. Londres: Centre for Educacional Studies. King's College. Relatório de pesquisa mimeo. 
Já as outras duas escolas pesquisadas parecem ter um público mais homogêneo. Uma delas tem um número grande de alunos dentro do seleto grupo dos que podem pagar "o preço absurdo das mensalidades" e, portanto, há uma variedade um pouco maior no perfil de alunos e pais. A outra, com um número menor, parece ter um público com perfil semelhante. Se por um lado, querem que o público da escola seja constituído por pessoas com os mesmos valores e mesmas condições econômicas, por outro, gostariam que seus filhos pudessem conviver com pessoas de todas as classes sociais, oportunidade que alguns deles tiveram porque estudaram em escolas públicas. Especialmente uma das mães que se mostrou muito satisfeita com tudo o que a escola proporcionou a seus filhos, afirma: "Não tenho nenhum arrependimento, mas eu fico pensando um pouco nisso [...]. Na época em que eu estudava, eu tinha vários grupos [...] tinha assim uma diversidade, mas eles (os filhos), numa cidade como São Paulo, não circulam tanto [...] eu sinto que eles ficaram restritos".

Nesse sentido, são muito valorizadas as "situações escolares" em que os alunos têm contato com outras realidades sociais. Numa das escolas os alunos podem participar voluntariamente de um projeto social com crianças de uma favela próxima. Entretanto, um casal aponta com muita clareza que trabalhos como esses são interessantes, mas não trazem a mesma experiência da escola pública: "A diversidade era tão favorável, tão bacana, relativiza tanto! E aqui estanca!". Mas essas considerações, na verdade, expressam a contradição em que vivem: ao proporcionar aos filhos um ensino de qualidade limitam seus laços sociais. Afinal, eles próprios revelam ter uma visão crítica da realidade - por isso, esperam que seus filhos também venham a desenvolvê-la. Essa situação também reforça a importância dada à educação escolar por essa camada social: entre estes dois aspectos que julgam importante para os filhos - ensino de qualidade e convivência com a diversidade -, lamentam a convivência restrita a uma única classe social, mas optam pelo ensino de qualidade. Até por isso revelam-se intolerantes com as pessoas da mesma classe social com valores mais elitistas, taxadas por um dos pais como "os amantes da grife e não do conhecimento".

Outra expectativa importante dos pais em relação às escolas dos filhos é que elas tenham estabilidade tanto na proposta pedagógica quanto no corpo docente. Assim, na escola em que houve mudanças na direção e no grupo de professores e na outra 
que passou por um processo de fusão entre duas instituições diferentes, que levou à demissão de professores e coordenadores, os relatos dos pais são permeados de insatisfações, críticas e até desconfianças. Uma das mães revela sua dúvida em matricular o filho mais novo na escola em que houve mudanças frequentes de diretores. Outra mãe (das escolas que se uniram) observa que escolheu uma e teve de "engolir" a outra, considerando o preço muito alto das mensalidades com estudos do meio e taxa de material: "O benefício não é proporcional, [...] alguém lucra com isso!". E há ainda o casal que relatou que a filha assistiu às aulas durante um mês com uma tarja preta no braço para protestar contra a demissão de professores e coordenadores e que a mãe "achou lindo"!

Entretanto, talvez a origem dessas insatisfações e inseguranças esteja menos nas mudanças em si e mais no receio de que elas tragam consigo profundas alterações nos valores e princípios educacionais das escolas - identificados por eles como os mesmos que os seus e um dos principais critérios de escolha. Até mesmo mudanças pouco significativas, como deixar de fazer a formatura num espaço alugado para fazer na própria escola, são recebidas com resistência e "rebeldia" por alunos e pais. Já na escola que apresentou grande estabilidade no corpo docente e na proposta pedagógica, o grau de satisfação dos pais era bastante alto e as eventuais mudanças eram vistas de maneira positiva, como indicativa da capacidade de renovação e de adaptação aos novos tempos. "Eu acho que a escola do meu tempo até agora avançou muito! [...] A gente se surpreendeu superpositivamente!", "[...] quando eu ouço os orientadores falarem sobre algum tema, acho que têm uma visão moderna, atual, [...] a escola está se renovando", são comentários de pais.

Ainda outra importante expectativa em relação às escolas que se pôde extrair do relato dos pais participantes é de que elas sejam capazes de conhecer bem as possibilidades e os limites de seus alunos, que tenham "um olhar individualizado para cada criança", de forma que os próprios pais se identifiquem com a descrição e com a avaliação que fazem dos filhos. A importância dessa capacidade foi quase uma unanimidade entre todos os pais, até porque, segundo Nogueira (1998), nessa camada social há uma preocupação em escolher estabelecimentos de ensino que se ajustem às características dos filhos. Um ensino que não seja massificado, em que "os filhos não fossem mais um entre muitos", mas, pelo contrário, poder "ouvir da orientadora descrições que combinam exatamente com a pessoa que a gente 
conhece lá em casa" são fatores fundamentais para reforçar a confiança e o apoio da família à escola.

Essa identificação é tão importante que os pais que não reconheceram o filho nas avaliações feitas por professores e orientadores, acabaram transferindo-o de escola. E esta pesquisa observou que todas as escolas procuradas, de alguma forma, conseguiam pôr isso em prática. Duas mantêm uma estrutura em que os orientadores entram em sala de aula com alguma regularidade para trabalhar questões com os alunos. Em outra parece que essa capacidade estava mais centrada na forma específica como um diretor mantinha contato com os alunos pelos representantes de sala, circulando muito nos corredores e nos arredores da escola - e que com a sua demissão, parecia ter se perdido, o que era a queixa de muitos pais.

Sem dúvida, a recíproca é verdadeira. Para os pais, tão importante quanto a escola conhecer bem seus filhos, é eles próprios conhecerem pessoalmente todos os professores, "saber como é a cara" e terem sua própria avaliação do trabalho que realizam. $E$ isso não acontece apenas quando os filhos estão no Ensino Fundamental I com a professora polivalente, mas no Ensino Fundamental II e no Médio também, quando passam a ter um professor para cada disciplina. Há uma queixa generalizada quando os professores não estão presentes em reuniões de pais ou quando o tempo maior é dedicado à fala de coordenadores e diretores. Uma das escolas organiza um encontro direto entre pais e professores que é muito elogiado: "Eu fui a esse encontro para conversar com dois professores [...]. Para mim foi incrível, porque de cara eu entrei com uma professora sensacional! Depois eu fui saber pela minha filha [...] que ela faz todo mundo adorar aquela disciplina", "[...] porque eu queria conversar mais, [...] tinha professores com que eu gostava de conversar".

São os professores que, de alguma maneira, parecem concretizar os princípios e valores educativos da escola e, portanto, são com eles que os pais compartilham o ato de educar. Daí a importância de conhecê-los e de manter contato frequente. Professores queridos pelos alunos certamente também serão queridos por seus pais, mas, eventualmente, alguns que não são tão bem-vistos pelos filhos, por serem exigentes e rigorosos, também acabam tendo o respeito dos pais. 
Principalmente quando os filhos se queixam dos professores, como no caso da professora de biologia da segunda escola, os pais consideram importante conhecer a pessoa para ter sua própria impressão dela antes de dar razão incondicional aos filhos.

Uma última expectativa comum dos pais identificada nas entrevistas é que as escolas tenham uma maneira menos técnica e mais humana e afetiva de conduzir o seu trabalho. Como se o fazer em educação dependesse menos de conhecimentos técnicos e teóricos e mais da experiência e do saber fazer. Chama a atenção o fato de que, em uma das escolas, a palavra "acolhimento" foi usada por todos os entrevistados para explicarem porque a escolheram, sendo que um dos pais foi além: "Não era uma coisa muito técnica [...]. A sensação que eu tinha era de um jeito honesto de ser, de ter uma coisa menos comercial". Em outra, o fato de o diretor atender pessoalmente todos os pais interessados de uma forma muito receptiva também parece ter sido decisivo na escolha. Uma das mães até não esclarece muitos critérios objetivos de escolha, mas fala que "tem muito essa coisa de sentir", além de ter gostado do modo como foi recebida, em contraposição a outros lugares em que "vinham vender os pacotinhos prontos!".

\subsection{E o que os pais criticam nas escolas?}

Foi interessante constatar que, diferentemente das expectativas e dos aspectos positivos, não houve, no levantamento dos problemas e nas críticas às escolas, uma convergência muito grande entre as ideias dos entrevistados. Não houve críticas semelhantes nem mesmo entre os entrevistados de uma mesma escola. Às vezes, um aspecto que era avaliado como positivo por um dos pais era visto como negativo por outros, ou vice e versa. No caso da terceira escola, por exemplo, uma mãe fez críticas muito contundentes à professora e ao curso de artes e outra não só elogia, como diz que esse é um dos pontos fortes da escola. Nessa mesma escola caso semelhante aconteceu com os estudos do meio: duramente criticados por uma das mães, que disse que os filhos depois nem se lembram do que foram estudar, mas muito bem avaliado por outros, que afirmam que neles "os alunos estudam de verdade". O mesmo se dá sobre o ensino religioso da primeira escola: enquanto alguns pais o colocam como uma das qualidades "muito mais de valores, de princípios mais universais", uma mãe afirma que "não acha moderno, acha que 
precisa ser repensado". Apenas na segunda escola houve mais pontos em comum, como a saída do antigo diretor da escola, o remanejamento de professores e o encaminhamento dado a um problema com uma das professoras.

Porém, houve uma crítica importante: o fato de os pais não se sentirem acolhidos ou ouvidos pelas escolas nas suas queixas e reclamações. Essa crítica refere-se principalmente ao fato de não se sentirem ouvidos, pois não esperam que a escola os satisfaça como se fossem clientes de uma loja ou supermercado, mas que se proponha a entender seus pontos de vista e que lhes apresentem, pelo menos, argumentos consistentes. Embora não tenha sido uma crítica comum a todas elas apenas em duas escolas duas mães disseram claramente que não se sentiam ouvidas -, em outra, pelo contrário, todos manifestaram surpresa e satisfação por terem sido prontamente acolhidos. Portanto, a capacidade da escola em ouvir os pais mostrou-se de suma importância para a manutenção de uma relação de confiança entre eles e a escola. Como não há "escola perfeita", a sua abertura para receber críticas e com elas aprimorar a sua prática é, na visão desses pais, fundamental para um bom relacionamento família-escola. De uma maneira geral, os estabelecimentos de ensino pesquisados parecem acolher bem as críticas dos pais.

Foram as mães que se voltaram mais para os problemas do que para os aspectos positivos nas entrevistas, que mais salientaram o fato de a escola demonstrar pouca disponibilidade para ouvir os pais e seus incômodos e citaram vários exemplos pessoais. Uma delas, até quando a pergunta era a respeito do que via de bom na escola, começou respondendo pelo o que via de ruim. No meio da resposta essa mãe ficou um pouco confusa, pediu para que se repetisse a pergunta, e quando se deu conta da troca que cometeu, riu. Para ela, "a escola só reflete sobre as críticas quando há uma evasão de alunos. De outro modo, a escola se coloca numa postura defensiva [...] é impermeável [...] isso me incomoda um pouquinho".

Outra mãe também apresentou muitas queixas e reclamações, revelando em alguns momentos até sentimentos de desconfiança e de frustração em relação à escola "eu fico desconfiada de que os donos lucram muito mais do que o bom senso exigiria [...] e eu sou bem recebida, mas as ideias param numa parede! [...] é uma das coisas que eu já desisti, porque [...] a escola tem um discurso cristalizado". Depois essa mãe comentou que ficou com a impressão de que seu depoimento 
acabou sendo muito negativo, mas que queria deixar registrado que gosta muito da escola, pois se não gostasse seus filhos não estariam lá. O relato dessas mães, entretanto, é indicativo de que mesmo as escolas que procuram estabelecer bons vínculos com sua comunidade de pais, até porque podem perder seus alunos se assim não o fizerem, têm uma tendência de se comunicarem de forma unilateral.

Por outro lado, os pais que tiveram algum tipo de problema relacionado aos filhos ou a procedimentos de professores e que, ao procurarem a escola, ela não só reconheceu que tinham razão, como se esforçou para resolver a questão, afirmam com toda a clareza que isso só aumentou a confiança que depositavam nela. Foi relatado, por exemplo, um caso de uma professora que desconfiou que a redação da garota não tinha sido escrita por ela, "porque as ideias eram muito adultas", e, quando a mãe procurou a escola, "a reação foi muito boa", pois a orientadora já sabia do caso e explicou para a mãe que a professora não era a da sala e que também estavam preocupados com casos de cópia que estavam aparecendo na escola. E também há o depoimento de outra mãe, que disse que a professora interpretou mal um trabalho da filha e, quando procurou a orientadora, ela foi muito receptiva, "em nenhum momento foi corporativista [...], saiu defendendo a professora ou pondo em dúvida o que minha filha estava falando". São posturas como essas que fazem com que os pais reconheçam que esses problemas são pontuais e não intrínsecos à proposta pedagógica da escola.

\subsection{Reunião de Pais}

"O que acham das reuniões de pais?"

Opiniões dos pais da primeira escola:

"Chatas, muito longas."

"Se acompanha muito pouca coisa, são grandes, eles falam e a gente escuta."

"Elas são muito gerais [...] é bem no superficial."

"É a mesma coisa." 
"Algumas muito boas, algumas cansativas e pouco esclarecedoras, [...] são interessantes, mas meio fraquinhas."

"Eles ficam horas explicando o sistema de recuperação [...], perdem tempo com essa burocracia [...], talvez pudessem ser menores."

Opiniões dos pais da segunda escola:

“É o que dá para fazer."

“Eu, particularmente, não gosto muito das reuniões.”

"Eu acho importantíssimo reunião de pais."

"Reunião de pais? Eu vou te falar uma coisa: eu não sei direito qual seria o modelo." Opinião dos pais da terceira escola:

"Eu sou do tipo que gosta de ir às reuniões de pais [...] eu acho que é um blábláblá importante de ouvir."

"Eu acho um saco aquilo ali!"

"Acho que a escola faz um esforço danado [...] para cumprir todos os itens que ela se propõe."

"Eu gosto, mas me canso."

"Eu sempre achei as reuniões muito elucidativas [...] sempre foi muito interessante, sempre!"

Todas as respostas foram colocadas em destaques porque é notável como a "chatice" das reuniões de pais é quase uma unanimidade entre os pais das três escolas. Quando não dizem explicitamente, usam termos indiretos, como "interessantes, é o que dá para fazer, não sei ainda qual o modelo", indicativos das restrições que possuem. Mesmo quem gosta, Diz: "gosto, mas me canso" ou usa termos como "blábláblá" e "esforço enorme", indicando que reconhece a sua importância e que as escolas se preparam para elas com cuidado, mas ainda assim acabam não agradando sempre e nem a todos. Apenas uma das entrevistadas foi categórica em dizer que são elucidativas e interessantes, até para se contrapor ao 
marido que reclamava da "chatice" e outro que optou por dizer que são importantes, sem caracterizá-la. Esse dado - a visão da maioria dos pais de que as reuniões são chatas - foi verificado também na pesquisa de Ribeiro (2006), realizada numa escola pública no interior de São Paulo: "As reuniões são chatas, cansativas e demoradas, gerando desinteresse da maioria" (p. 390).

É importante acrescentar que, pelas descrições dos pais, os modelos de reuniões das três escolas eram diferentes: na primeira, as reuniões eram organizadas como grandes palestras da direção, coordenação e alguns professores, feitas no teatro da escola para todos os pais de determinada turma e nas quais eles não tinham muito como se colocar. Na segunda, a participação da direção ou da coordenação se dava no início, apenas para esclarecimentos gerais, e depois os pais procuravam cada um dos professores para falar especialmente dos seus filhos e, para isso, tinham de enfrentar filas. E na terceira escola, havia também reuniões mais gerais para se falar do trabalho mais amplo que seria desenvolvido na série, com a presença da coordenação e de alguns professores, só que para um número menor de pais, o que permitia que eles se colocassem. Além disso, a escola oferecia um encontro em outro dia para que os pais conhecessem melhor os professores.

Agora, por que são "chatas"? Apesar das diferentes maneiras pelas quais as reuniões são organizadas e conduzidas pelas escolas, as razões da chatice parecem ser recorrentes. A primeira delas é o fato de alguns pais "monopolizarem" as reuniões com questões particulares dos seus filhos ou com assuntos que não são do interesse de todos. Há o relato de um pai, por exemplo, que teve de ouvir durante "horas" uma discussão sobre a venda de chocolates na cantina. Em situações como essa, o que incomoda mais é que a escola não intervém e acaba deixando os interesses individuais prevalecerem sobre os do grupo, desviando-se da pauta divulgada anteriormente. $E$, nas reuniões em que os professores ficam à disposição para conversar, a queixa é também de que uns pais monopolizam o tempo, "ficam meia hora" e a fila não anda, fazendo com que alguns até desistam.

Outra razão da chatice é quando a escola dá ênfase a procedimentos ou conteúdos que vai trabalhar, fazendo longas exposições, e não à caracterização dos alunos e à apresentação dos professores. Então os coordenadores passam muito tempo explicando a sistemática da recuperação, como disse uma das mães, ou ficam 
ensinando conteúdos aos pais, como descreve outro casal que assistiu "a uma aula sobre o ciclo do café". Essa também é a visão de Caetano (2003): "As reuniões baseadas em temas teóricos e abstratos [...] onde só o professor pode falar, não tem proporcionado sequer a abertura para iniciar de uma proposta de parceria" (p.7). que os participantes apontam é que se interessam mais pelo dia-a-dia das crianças na escola, como estão interagindo e se desenvolvendo, e menos pelos conteúdos trabalhados. Também acham importante conhecer todos os professores, "ver a cara" de quem ouvem falar em casa, como já foi exposto anteriormente, ou seja, reuniões sem a participação dos professores não são tão interessantes.

Talvez por todas essas razões levantadas as reuniões individuais foram mais bem avaliadas pelos participantes - quase todos tinham a prática de marcar reuniões individuais com a escola para esclarecer questões relativas aos filhos ou para falar sobre procedimentos e encaminhamentos mais gerais. Nelas, não há a monopolização de outros pais, o horário é exclusivo para eles, podem se aprofundar nas questões individuais dos filhos, e os orientadores trazem descrições de situações mais concretas. Assim, os contatos individuais acabam sendo, do ponto de vista dos pais, mais objetivos e proveitosos. Como disse um pai: "Talvez o mais legal fosse a gente se reunir para falar só do nosso filho!", embora reconheça que isso seja inviável.

A chatice das reuniões coletivas, entretanto, parece ser mais tolerada pelas mães do que pelos pais. Entre os casais de todas as escolas, as respostas à pergunta "Como vocês se organizam para ir às reuniões?" foram:

- Três casais vão juntos quando podem, mas a mãe costuma ir mais porque tem mais flexibilidade de horário;

- Três casais vão juntos em apenas algumas (nova escola, início de ciclo ou quando há algum problema), mas é a mãe quem costuma ir porque gosta mais. Os maridos se informam com ela;

- Só a mãe vai à reunião; o marido nunca foi;

- Pai e mãe vão juntos sempre, "fazem questão"; 
- O pai vai sempre, pois é o que cuida da filha com a atual esposa, e não com a mãe biológica.

Parece que a realidade confirma o contexto ficcional criado pelo escritor Fernando Sabino (2003) em sua crônica "Reunião de Mães":

Na reunião de pais, só havia mães. Eu me sentiria constrangido em meio a tanta mulher, por mais simpáticas que me parecessem, e acabaria nem entrando - se não pudesse logo distinguir, espalhadas no auditório, duas ou três presenças masculinas que partilhariam de meu ressabiado zelo paterno (p. 211).

É também o que observa uma das mães que sempre comparece às reuniões com o marido: "[...] é engraçado, porque, sejam casados ou separados, os homens não vão às reuniões! [...] Parece que escola não é lugar de homem adulto".

Entre as mães separadas acontece um fenômeno semelhante: elas vão mais às reuniões coletivas do que os pais; eles vão mais em função da cobrança dos filhos. Apenas uma das mães disse que o ex-marido nunca vai e nunca foi, mesmo quando eram casados. Eventualmente os pais marcam entrevistas individuais na escola, sem as mães. No entanto, quando é a escola quem marca a reunião, os dois procuram ir mesmo que nem sempre ao mesmo tempo. Já os casais costumam comparecer juntos às reuniões especiais sobre os filhos.

O que é curioso nesses dados é que, entre esses participantes, os homens mostraram prazer em compartilhar com a mulher a educação dos filhos e quase todos eles participaram ativamente da escolha da escola. Entretanto, a mesma disponibilidade não é encontrada para frequentar as reuniões de pais. Alguns até reconhecem que acabam se interessando e gostando do que ouvem da escola: "Eu fico fascinado com a maneira com que eles trazem as questões para os alunos ou como eles aproveitam as questões dos alunos para passarem o que querem [...] eu gosto dessas conversas!", "Eu gostei muito do discurso deles! Até porque eu dou aula em universidade [...] eu aproveitei muito a conversa!". Mas, mesmo assim, são poucos os pais que "fazem questão" de ir ou que são "superatuantes". 
Embora as mulheres concordem com as críticas que seus maridos fazem às reuniões, consideram importante participar para acompanhar melhor a escolaridade dos filhos e "pronto!" Talvez esse fato seja indicativo de que, apesar de esses casais compartilharem as tarefas da casa e da educação e não terem uma divisão de papéis tão rígida, os filhos ainda ficam mais sob a responsabilidade das mães do que dos pais. Mesmo com uma intensa vida profissional, como algumas delas revelaram ter, as mulheres conseguem se organizar melhor para cuidar dos filhos do que seus maridos. Talvez por aspectos afetivos e psicológicos e/ou culturais e sociais, o cuidado com a prole ainda parece ser mais uma tarefa feminina do que masculina. Mas não cabe aqui o aprofundamento nessa questão de gênero.

Todavia, a importância de frequentar as reuniões de pais também foi um ponto em comum entre todos os participantes. Todos responderam que costumam ir, só não vão quando há coincidência com algum compromisso de trabalho e muitos consideram que poderia haver mais reuniões. Em geral, pelo que relatam, as escolas costumam fazer uma ou duas reuniões por ano, que são, sem dúvida, importantes para os pais se apresentarem, para conhecerem os professores dos filhos e também para fazerem um acompanhamento mais contextualizado do que os filhos estão aprendendo. Na visão de uma das mães: "Ajudava mesmo no acompanhamento [...] a gente não estava sacando que tinha uma dificuldade". E de outra: "Quando o professor fala do projeto que ele desenvolve [...] você vê que é diferente, são coisas [...] que você não consegue perceber nas falas dos alunos".

Mais do que isso, alguns pais disseram que eles próprios sentem que aprendem quando participam de boas reuniões de pais. Para uma das mães participantes, um dos aspectos positivos da escola da filha até o Ensino Fundamental era que a escola se preocupava com a formação dos pais, explicando, por exemplo, as fases do desenvolvimento das crianças. E outro pai participante afirma: "[...] o pai acaba sendo educado também! [...]. Se forem bem preparadas pela escola, elas funcionam como um processo de educação também para os pais!". Como dito anteriormente, os participantes dessa pesquisa são pais e mães que não delegam a educação integral dos filhos à escola, mas fazem questão de participar, de compartilhar, de se manter informados sobre o trabalho que a escola realiza e como seus filhos estão se saindo. 
O modelo de reunião de pais mais bem avaliado pelos participantes é aquele em que há, além da coordenação da escola, a participação de alguns professores para explicarem alguns aspectos do seu planejamento de ensino, além de haver também um grupo de participantes não muito grande, pois assim os pais podem, eventualmente, apresentar suas ideias. Nas reuniões muito grandes, eles consideram constrangedor fazer perguntas diante de tantas pessoas e também dizem que quase não há tempo para isso. Um tipo de reunião elogiado também é aquele em que os pais podem conversar diretamente com os professores, sem a mediação da coordenação. Também as reuniões temáticas sobre drogas e/ ou adolescência foram bem avaliadas. 


\section{CAPÍTULO 4}

\section{DISCUSSÃO:}

\subsection{O perigo das generalizações}

É fato que o número de divórcios tem aumentado no Brasil, assim como nas grandes cidades da Europa e de toda a América, fazendo com que surjam novas configurações familiares - mulheres chefes da família, crianças convivendo com padrastos e madrastas, com meios irmãos de outros casamentos, tanto do pai como da mãe, etc. Mas isso não é necessariamente indício de que as famílias estão em crise, de que os pais não se preocupam com os filhos e não se dedicam a eles ou de que esses novos arranjos familiares são prejudiciais ao desenvolvimento e ao aprendizado de crianças e jovens.

Como já foi considerado, entre as famílias pesquisadas havia vários tipos de configuração familiar, e em todas elas os pais se mostraram bastante envolvidos com a educação dos filhos. Sem dúvida, como observa Caetano (2003), se as relações familiares não vão bem, podem influenciar negativamente o desenvolvimento escolar dos filhos. Uma separação litigiosa, em que pai e mãe brigam na justiça pela guarda dos filhos, por exemplo, deve trazer sofrimentos emocionais que refletem negativamente no processo de aprendizagem. Mas, também um casamento em que pai e mãe discutem o tempo todo, pautado por violência verbal e/ou física não constitui um ambiente saudável para o desenvolvimento dos filhos. Não são os novos arranjos em si que trazem prejuízos às crianças e jovens, mas o modo como eles são conduzidos pelos adultos. Afinal "[...] achamos preferível que cada um seja pai com sua história, com seu inconsciente" (ROUDINESCO, 2003, p. 197).

É fato também que a mulher entrou definitivamente no mercado de trabalho, deixando de se dedicar unicamente ao lar e aos filhos, o que impôs a necessidade de a família contar mais com instituições educacionais, como creches e escolas para a educação integral das crianças. Assim, como coloca Enguita (2004), elas ficam mais tempo nas escolas - entram mais cedo, em termos de idade, saem mais tarde, e permanecem mais dias durante o ano. Pais e mães ocupados, como os que 
participaram da pesquisa, são obrigados a compartilhar com as instituições educacionais parte do cuidado com os filhos.

Entretanto, como indicam nossos resultados, isso não significa que esses pais não se sintam capazes de transmitir valores morais e disciplina aos filhos ou que estejam delegando a tarefa exclusivamente às escolas. Um dos pais entrevistados, inclusive, foi bem claro: "[...] a gente não vai delegar para a escola o papel de disciplinar os filhos e não ter controle nenhum deles". Se a relação com a família e com os filhos é um valor, nos moldes do que diz Ferry (2008), mesmo sendo muito atarefados, alguns pais e mães encontram espaço e tempo nas suas agendas para conviver com os filhos e para acompanhar o desenvolvimento e a escolaridade deles. Até demonstram interesse em participar mais da vida escolar.

Ainda é possível inferir, a partir dos depoimentos, que os participantes não se identificam com modelos educacionais autoritários ${ }^{15}$, que impõe regras de condutas sem se preocupar em explicar o sentido delas e buscaram escolas com visão semelhante a deles próprios. Não valorizam a obediência cega e submissa - há inclusive um pai que identifica a contradição em uma das escolas, que procura desenvolver o pensamento crítico, mas, em determinado momento, exige obediência e aceitação às suas decisões. Entretanto, não se mostraram vulneráveis e permissivos às vontades dos filhos, nem submissos às suas próprias culpas, como traz Donatelli (2004). Nessas famílias não se evidencia uma crise de autoridade, mas a preocupação de que o exercício dessa autoridade se dê de maneira afetuosa, justa e coerente, que a obediência advenha do respeito, e não do medo. E é essa a relação que esperam que os educadores também estabeleçam com seus alunos.

Todos esses aspectos estão sendo retomados para evidenciar que a visão recorrente entre educadores de que as dificuldades de aprendizagem e de comportamento dos alunos nas escolas são frutos de famílias 'desestruturadas', que não se interessam pelos filhos e não Ihes ensinam disciplina e respeito ao próximo, não condiz com os resultados obtidos nesta pesquisa. Foi verificado, em nossa pequena amostra, que mesmo pais interessados e participativos podem ter filhos

\footnotetext{
${ }^{15}$ Hanna Arendt (1997) faz uma distinção entre autoritarismo e totalitarismo. Para ela, o regime autoritário é hierarquizado e pautado em leis, enquanto o totalitário é regido unicamente pelas vontades e desejos do governante. Talvez o mais correto aqui seria usar o termo totalitário.
} 
com dificuldades escolares. E talvez, entre os bons alunos, podem haver pais desinteressados e indiferentes à sua escolaridade.

Como diz Gomes (2007), "Não há dúvida: toda generalização é perigosa" (p.85). Esse tipo de explicação genérica pode, muitas vezes, mascarar preconceitos, com alerta Patto (1997). Mas essa generalização causa também outro enorme prejuízo aos aprendizes e ao ensino em geral: o desvio do foco de análise para fora da escola. Antes de atribuir os problemas de aprendizagem e de comportamento dos alunos a fatores externos e alheios a sua intervenção, as instituições escolares deveriam investigar e diversificar suas próprias práticas de ensino, principalmente para os alunos com mais dificuldades. Para estabelecer uma parceria efetiva com as famílias, é preciso levar em conta que há famílias que podem ou não estar em crise, que há pais que sentem dificuldade de impor limites aos filhos e outros, que o fazem com tranquilidade. Há pais interessados e envolvidos; outros, negligentes e indiferentes. Há crianças cuja dinâmica familiar interfere muito no seu processo de aprendizagem e outras que interfere pouco, ou seja, a escola deve pressupor a diversidade das famílias, e não um modelo idealizado e pré-concebido.

\subsection{Novas perspectivas para a parceria família-escola}

Além de a família contar mais, e talvez exclusivamente, com a escola para educação dos filhos, uma vez que outras instituições socializadoras desapareceram ou se retraíram (ENGUITA, 2004), a família e "seu jeito" de educar, pautados na tradição e na experiência pessoal de pais e mães, sofreu a interferência intensa de especialistas em saúde, desenvolvimento infantil e educação (LASH, 1991). "Perante os novos técnicos em amor familiar, os pais, via de regra, continuam sendo vistos como ignorantes, quando não doentes. Há sempre um a mais a corrigir, um a menos a tratar. Amar e cuidar dos filhos tornou-se um trabalho sobre-humano, mais precisamente científico" (COSTA, 2004, p. 15).

Hoje, em vez de pais e mães recorrerem à sabedoria dos mais velhos para resolver problemas de saúde ou de comportamento dos filhos, fato comum há algumas gerações, buscam médicos, psicólogos, psicopedagogos etc, que são consultados não apenas quando há problemas, mas também para instruí-los e orientá-los nas 
suas ações cotidianas. Entre os pais pesquisados, por exemplo, muitos, para escolherem a escola, ouviram a opinião de educadores. $E$ também diante de dificuldades de aprendizagem, recorreram a vários tipos de especialistas. Outro exemplo disso, que não tem a ver diretamente com a pesquisa, é a difusão cada vez maior de cursos para casais grávidos oferecidos nos consultórios de obstetras e nas maternidades, que abordam desde questões técnicas, como dar banho, trocar fraldas, fazer arrotar etc, como questões psicológicas, como a depressão pós-parto.

Por outro lado, a escola também foi pautando suas práticas cada vez mais no pensamento científico, a ponto de o ensino atualmente não dispensar conhecimentos oriundos da pedagogia. Hoje nenhuma escola ignora, por exemplo, as principais ideias de Piaget, Vygotsky ou Freud. Se formos fazer uma análise minuciosa de como as escolas pesquisadas se apresentaram, poderemos identificar a presença das ideias centrais desses pensadores. Não que todas façam boas transposições para a prática educacional, mas todos os educadores reconhecem que o desenvolvimento infantil passa por fases, tanto cognitivas, como psíquicas, que o pensamento se desenvolve do concreto para o abstrato e a importância de as crianças elaborarem juntas suas próprias hipóteses explicativas sobre o que observam. A prática pedagógica e educacional foi invadida pelo conhecimento dos especialistas, ou melhor, talvez tenha se construído apoiada em diferentes áreas do conhecimento.

Mas, embora a pedagogia procure se pautar nos conhecimentos de outras áreas, como a medicina e a psicologia, ela não se caracteriza como uma prática estritamente técnica e exata. Em função disso, as famílias entrevistadas parecem não estabelecer com a escola e seus educadores a mesma postura que assumem nas consultas médicas, por exemplo. O conhecimento pedagógico é menos preciso e mais discutível do que o conhecimento de outras áreas, como a medicina, o direito, a engenharia etc. Como relata um pai, uma das razões da escolha da escola foi exatamente a predominância de aspectos afetivos e menos técnicos. Por outro lado, uma das características desse grupo de pais com alto capital cultural é o fato de eles se tornarem "profissionais no acompanhamento escolar [...] mantendo-se informados sobre o que se passa na escola e buscando elementos para compreender as bases do trabalho pedagógico" (PAIXÃO, 2007, p. 36). E esta é justamente uma queixa da escola: a de que as famílias não seguem precisamente 
suas orientações e muitas vezes questionam sua prática pedagógica, "[...] já não aceita com facilidade uma posição de subordinação obsequiosa perante os professores [...]" (ENGUITA, 2004, p. 62).

Por sua vez, muitos pais entrevistados e com um bom relacionamento com a escola dos filhos afirmaram aprender muito com ela, seja sobre assuntos técnicos como alfabetização, seja sobre questões mais amplas. Então, pode-se concluir que os pais que reconhecem a escola dos filhos como um espaço para o próprio aprendizado seguem mais suas orientações e estabelecem um bom relacionamento com ela? Também não foi isso exatamente o que pôde ser constatado. Apesar de identificarem e valorizarem o fato de aprender com a escola e seus educadores, os pais não se mostraram submissos a eles. Afinal, foram muitos os relatos de pais que procuraram a escola para discutirem alguns de seus encaminhamentos ou para deixarem claro que não concordaram com algumas de suas decisões. Afinal, quanto mais valor os pais atribuem à educação, mas exigentes se tornam (NOGUEIRA, 1995). A relação esperada e, na maior parte das vezes, estabelecida era de reciprocidade e não de submissão, tanto que o fato de suas críticas e sugestões serem ignoradas é gerador de insatisfação e insegurança.

Talvez, a partir dessas considerações, possa ser traçado um caminho para que a parceria família-escola se dê de maneira mais efetiva. Significa reconhecer que a escola também pode ser um espaço de formação para pais e mães, uma vez que esse aprendizado não ocorre naturalmente. Há menos troca de saberes entre as gerações e maior valorização do conhecimento dito "científico". Repetindo a observação de um pai, "[...] nas reuniões o pai acaba sendo educado também! [...]. Se forem bem preparadas pela escola, elas funcionam como um processo de educação para os pais." Porém, nesse espaço formativo, a escola não deve tentar impor seu conhecimento técnico às famílias, mas, pelo contrário, deve criar espaços para que elas reflitam sobre suas próprias práticas educacionais. Quanto mais a escola assumir seu papel de especialista em educação, mais os pais podem sentirse inseguros e incapazes de atender às suas orientações e recomendações, que é o que ocorre mais frequentemente nas camadas populares (NOGUEIRA, 1991; RIBEIRO, 2006; PAIXÃO, 2007). A reação, nesse caso, é de afastamento não só da escola, mas do próprio acompanhamento da vida escolar dos filhos. "Ao negar essa assimetria, a escola termina assumindo seu local de poder, estabelecendo uma 
relação instituída com os pais, sem conseguir, no entanto, uma aliança eficaz" (RIBEIRO, 2006, p. 393).

Há alguns autores que relatam experiências parecidas com a que a está se esboçando. Paro (2000) relata a iniciativa da direção de uma escola pública de periferia que ofereceu um espaço de formação de pais "[...] com objetivo de discutir com pais e mães dos estudantes questões relacionadas à educação, à escola e à vida dos filhos e filhas" (p.105). Esses pais eram convidados não apenas para receber informações escolares sobre os filhos, mas também para falar sobre suas preocupações com eles. Mais do que falar, a escola se dispunha a ouvi-los, criando um espaço de conversa e reflexão entre eles. Essa experiência ressalta o real interesse da direção na participação dos pais, pautado por uma dimensão dupla "[...] de direito dos usuários a um serviço público, e da necessidade de a escola de contar com a colaboração deles para desenvolver suas funções” (PARO, 2000, p.106).

Szymanski (2000) também propõe um programa de formação de pais mais voltado às famílias desfavorecidas, que acabam sofrendo mais com o preconceito e com a exclusão social e estão mais sujeitas a práticas educacionais autoritárias, pois "[...] o autoritarismo e as punições físicas são consideradas recursos para evitar a delinquência" (p.20). Esse trabalho se daria a partir das concepções de Paulo Freire entre a educação bancária e a problematizadora.

\footnotetext{
Um olhar educativo para a família sugere que as práticas podem ser aprendidas e/ou modificadas segundo uma proposta educacional, e que os pais, enquanto educadores, podem ser sujeitos de um programa de formação. Este seria um serviço importante a ser oferecido às famílias, já que se cobra tanto sua participação na educação de crianças e jovens e seu envolvimento em outras instituições educativas, principalmente a escola (SZYMANSKI, 2000, p. 19).
}

O que se propõe, a partir dos depoimentos dos participantes desta pesquisa e de toda a literatura consultada, é que a escola ofereça, além das reuniões de pais já existentes, encontros em que os pais possam conversar e discutir entre eles questões relacionadas à educação dos filhos. A escola e seus representantes assumiriam uma posição de mediadores das discussões, e não de coordenadores da atividade. Assim se estabeleceria outra forma de se relacionar com pais, pautada 
mais na reciprocidade e na responsabilidade mútua sobre a tarefa de educar do que na assimetria e na imposição de um modelo sobre outro. Cabe à escola, portanto, tomar a iniciativa.

Essa modalidade não substituiria as tradicionais reuniões de pais, porque, de fato, informar às famílias sobre os objetivos do trabalho pedagógico e de como ele se desenvolve é papel da escola. Afinal, ela tem uma função específica diferente da família: a de transmitir o saber sistematizado da humanidade para as novas gerações não só para preservar esse saber, mas também para que ele seja transformado e reelaborado pelas novas gerações. Em geral as famílias pesquisadas não questionaram essa especificidade. Um casal disse, por exemplo: “Tem mães que dizem 'meu filho não vai ler este livro, não vai ver este filme!' Nós não. Não vamos ficar questionando. Esse tipo de decisão não é à toa, não cabe a nós questionar!". Quando percebem que o ensino não está se desenvolvendo a contento é que questionam as escolas - como fazem os pais da segunda escola ao ouvirem as reclamações dos filhos sobre a mudança de professores. Nesse caso a escola não deve assumir uma postura reativa e defensiva, mas se contrapor às queixas com sua avaliação do trabalho dos profissionais. Se os pais têm razão, admitir isso não é dar poder a eles, mas, pelo contrário, é reforçar seus laços de confiança. E se for um caso isolado de reclamação, como no caso da professora de artes da terceira escola, a escola deve criar condições para que a família perceba isso.

Um último aspecto que deve ser analisado para reforçar a parceria família-escola: como a escola se comunica com as famílias. Tanto alguns dos entrevistados, quanto a literatura, apontaram que muitas vezes a comunicação com as escolas é de mão única - a escola manda circulares e informativos, mas não responde aos bilhetes e/ou e-mails dos pais. Em geral, a escola corre para informar sobre problemas de aproveitamento e de comportamento, mas nunca para dar boas notícias. Uma das mães, inclusive, relata que quando o diretor telefonou para ela para falar sobre a presente pesquisa, foi logo esclarecendo que não era nada sobre o filho dela, o que a deixou aliviada... Nas conclusões da pesquisa realizada por Marques (2002), ele afirma "[...] notou-se o uso persistente e continuado, em todas as escolas, de formas de comunicação negativas [...]" (p. 5). Esse fato aponta para a necessidade de a escola criar formas eficientes de comunicação com as famílias, levando em conta 
que comunicar é um processo dialógico, ou seja, "[...] implica numa reciprocidade que não pode ser rompida" (FREIRE, 2002, p. 67).

Obviamente que há de se considerar também que o número de pais é sempre maior do que o número de profissionais da escola. Mas, mais do que pensar em meios concretos sobre como responder os e-mails ou retornar as ligações dos pais, é importante que os educadores tenham clareza de que devem se comunicar com seus alunos e suas famílias, e não apenas informá-los sobre as atividades escolares. Com essa concepção, os próprios recursos já existentes, como cartas, circulares e e-mails serão utilizados com mais propriedade e podem se tornar mais eficientes. Para as escolas com condições de aprimorar os canais de comunicação boletins informativos, jornais, sites, blogs etc. são bem-vindos porque ampliam as formas de contato com a comunidade.

Outra prática importante para aprimorar a comunicação com os pais e tornar o acompanhamento escolar dos filhos mais efetivo é convidá-los para atividades em que os alunos possam mostrar os avanços de seu aprendizado. Nas escolas que promoviam apresentações de trabalhos, saraus literários, feira de ciências, etc., os pais não só fizeram avaliações positivas dessas atividades como indicaram que gostavam mais delas do que das reuniões de pais, justamente por observarem diretamente o trabalho das crianças. Essas situações são oportunidades para os pais comparecerem a escola em função de aspectos positivos do trabalho de seus filhos.

Mais do que a prática de fazer com que os alunos apresentem o que fizeram ou aprenderam para os pais e colegas em eventos, como feira de ciências, seminários, etc., as escolas deveriam promover essas atividades sobre a perspectiva da socialização. Socializar implica comunicar o que aprendeu, como aprendeu e por que aprendeu, e não apenas expor o conteúdo do aprendizado. A mera apresentação é pautada na hierarquia e só é capaz de socializar quem de fato se tornou sujeito do seu processo de aprendizagem. Entretanto, a prática da socialização, que na visão de Paulo Freire (1970) é intrínseca ao próprio ato de educar, não deve ser incentivada apenas entre os alunos, mas deve permear as ações educativas e pedagógicas de toda a equipe de trabalho da escola entre si e para a comunidade. Para cumprir a contento o seu papel de socializar o saber 
sistematizado da humanidade, a escola precisa também socializar suas práticas educacionais e pedagógicas, pois só assim estabelece relações simétricas, pautadas na reciprocidade com a comunidade da qual faz parte.

Em síntese, a escola, para estabelecer uma parceria mais efetiva com as famílias, deve:

- Desenvolver uma visão crítica e histórica das famílias e não se ater a um modelo único, idealizado e pré-concebido;

- Compreender que fatores históricos e sociais levaram as famílias a contarem cada vez mais com a escola para educar os filhos, o que não significa que elas delegam exclusivamente essa tarefa à escola. E, como corresponsável na formação integral das crianças e jovens, a escola deve se colocar numa posição de reciprocidade com os pais. Daí a importância de se comunicar bem e de socializar suas práticas.

- E, finalmente, reconhecer que ser pai e/ou mãe não é tarefa natural e espontânea, mas algo que se aprende a partir da relação construída e vivida com os filhos. No sentido de favorecer esse aprendizado dos pais, a escola deve promover ações para que eles reflitam sobre suas práticas educacionais.

\subsection{Ideias para aprimorar as reuniões de pais}

Garcia (2005) na conclusão de sua pesquisa sobre reunião de pais na Educação Infantil em escolas públicas diz:

Reunião de pais, que espaço é esse? [...] São espaços em que a escola muitas vezes ensurdece, sobrecarregada pelas pressões e frustrações que envolvem diariamente a equipe escolar. São espaços em que, por ficar no campo do conhecido daquele que fala, a escuta do outro (família), morada do desconhecido, fica ausente. São espaços onde mostramos ser possível a efetivação de momentos de troca e de respeito pelas diferenças. Onde a construção e a criatividade tornam-se possíveis. Espaços que, para poderem acontecer, têm dependido de não poucos esforços da parte das escolas e dos pais, mesmo que nem sempre tenham sido mutuamente reconhecidos (p. 185). 
A partir do relato dessa autora de que as reuniões de pais podem ser espaços de conflitos, mas também um meio para se efetivar a parceria família-escola, das recomendações levantadas no item anterior e do relato dos participantes da pesquisa, cabe sugerir algumas ideias para transformar a forma como as escolas conduzem as reuniões. Pôde-se constatar que as reuniões mais bem avaliadas são as que não têm um número muito grande de participantes, o que permite que os pais se sintam à vontade para fazer perguntas, pedir esclarecimentos ou mesmo para levantar outras questões a serem discutidas. Talvez uma possível solução para evitar que alguns pais monopolizem a reunião com questões que não são do interesse do grupo seja a escola oferecer, junto com o lembrete do dia, da hora da reunião e da pauta, um espaço para que os pais sugiram temas e questões a serem discutidas nas reuniões. Dessa maneira, posteriormente, na abertura da reunião, a coordenação retoma a pauta proposta pela escola, as pautas sugeridas pelos pais e estabelece que outros assuntos que não foram previstos só serão discutidos se houver tempo no final da reunião.

Muitas vezes questões ou dificuldades individuais de uma família levam a boas discussões e aprendizados para o conjunto dos pais, em vez de aborrecê-los por julgarem que o assunto não tem nada a ver com eles. Na verdade, algumas mães relatam que, às vezes, uma pergunta ou observação de outros pais também pode ser interessante, "sempre se acaba aproveitando". Eventualmente o posicionamento de outros pais sobre uma questão pode ajudar mais do que a resposta ou a posição da escola. É possível que se todos os pais da terceira escola pesquisada pudessem discutir juntos a questão do estudo do meio, a mãe que fez duras críticas percebesse que outros pais pensam diferente e que o estudo é mantido não só porque é uma fonte de renda, mas porque há o apoio da comunidade e porque parece ser uma atividade significativa para outros alunos. Mesmo uma reunião em que um dos itens fosse o que a escola deve vender na cantina não traria tantos aborrecimentos para um pai. Todavia, esse modelo exige que a condução da reunião seja firme e não permita que se desvie da pauta, ou seja, deve-se interromper observações que não têm a ver com o assunto e retomar o foco da reunião. A objetividade e uma pauta bem definida que é cumprida são características valorizadas pelos pais. Isso é o que indica também o estudo de 
Ribeiro (2000). Talvez as reuniões pudessem ser encerradas com uma breve avaliação e sugestões para o próximo encontro.

Em escolas em que se opta por uma rápida explanação inicial, seguida de um tempo para que os pais conversem diretamente com os professores, é importante que esses professores sejam orientados para limitarem o tempo de conversa com cada família, a fim de que todas possam procurá-los. Talvez pudesse haver um espaço no início para que os pais se inscrevessem em horários que os professores respeitariam. Em escolas que contam com um bom sistema de informática, essa inscrição pode ser eletrônica. Aqui, vale destacar que a presença dos professores em reuniões é extremamente importante para os pais, seja explanando sobre seu planejamento de ensino, seja colocando-se à disposição para tirar dúvidas. Como muitos pais disseram, querem ver a cara e ter as suas próprias impressões de quem tanto ouvem falar. E para os ciclos de Educação Infantil e Ensino Fundamental I, em que as reuniões são conduzidas pelos próprios professores, é fundamental que eles tenham autonomia para prepará-las. "O processo de preparação e o resultado de uma boa reunião de pais estão nas mãos do próprio professor e não no coordenador ou diretor da escola" (ALTHUON; ESSLE; STOEBER 2005, p. 22).

Outra sugestão importante para coordenadores e diretores que realizam reuniões de pais ou que as preparam junto com professores é que suas falas sejam centradas no dia-a-dia das crianças e dos jovens na escola, e não em longas explanações conceituais e teóricas sobre conteúdos ou metodologia de ensino. Embora os pais até se interessem pelo processo de alfabetização, por exemplo, ele possivelmente vai apreciar mais a reunião se ouvir como se dá esse processo na escola, na turma e com seu filho, aspecto já verificado por outros pesquisadores (CAETANO, 2003; GARCIA, 2005). Explicar como e porque um trabalho é desenvolvido, ilustrando com dados concretos da sala de aula e não em função de fundamentos teóricos, é muito mais esclarecedor para os pais. Assim, a escola poderia preparar murais, com algumas produções dos alunos que mostrem o que estão fazendo, ou exposições de fotos e pequenos vídeos em que o cotidiano de sala de aula seja retratado. Esses recursos ajudam os pais a entenderem melhor os objetivos e a metodologia de ensino da escola. 
Vale destacar também que as reuniões temáticas foram bem avaliadas pelos pais. São reuniões, como relatado por alguns participantes, em que eles aprendem algo novo ou que os fazem pensar. Assim, é interessante a escola promover, ainda que de forma eventual, palestras, debates e encontros com especialistas de diversas áreas. Os temas poderiam ser recolhidos com os pais, da mesma maneira como as sugestões de pautas, ou propostos pelos próprios coordenadores a partir de questões surgidas nas reuniões sistemáticas, tais como adolescência, internet e drogas. Nesses encontros temáticos, o aprofundamento teórico e conceitual parece mais adequado. É importante lembrar que reuniões frequentes sobre um tema específico tendem a se esvaziar - foi essa a experiência da terceira escola narrada por uma mãe. Isso talvez aconteça porque os pais não querem se transformar em especialistas nessas temáticas, mas apenas sentem necessidade de ouvir um pouco sobre elas para entender melhor o momento de vida dos filhos.

\subsection{Sobre algumas políticas públicas de integração família-escola}

Como sugerido na Apresentação deste trabalho, estreitar os laços entre família e escola pode ser uma maneira de elevar a qualidade de ensino. Muitas pesquisas indicam que o acompanhamento dos pais resulta em melhor desempenho escolar (PINHEIRO, 2007; POLONIA; DESSEN, 2005; PEREZ, 2004; CHECHIA, 2002; MARQUES, 2002; FRAIMAN, 1997). Também em documentos oficiais do governo essa aproximação é bem-vinda: "A pesquisa apontou para um desejo dos pais ou responsáveis de intensificar a relação família-escola. Essa intensificação poderá ser estratégica na elevação da qualidade do aprendizado" (PACHECO; ARAÚJO, 2005, p. 19). Entretanto, no levantamento feito nesta pesquisa encontrou-se apenas uma ação governamental de grande porte com o objetivo de aproximar as famílias da escola: o programa "Escola da Família”, do governo estadual de São Paulo.

É uma iniciativa que une [...] profissionais da educação, [...] estudantes universitários, [...] e voluntários para criar uma cultura da paz, despertar potencialidades e desenvolver hábitos saudáveis junto aos mais de 7 milhões de jovens [...]. O objetivo deste programa é a abertura, nos finais de semana, de 2334 escolas da Rede Estadual de Ensino, transformando-as em centro de convivência, com atividades voltadas às áreas esportiva, 
cultural, de saúde e de trabalho (PROGRAMA ESCOLA DA FAMÍLIA http://escoladafamilia.fde.sp.gov.br/apresentacao.htm).

Como se pode verificar é um programa que abre a escola para a comunidade nos fins de semana, mas cuja prioridade é o trabalho com jovens, e não com suas famílias, com a intenção de diminuir a violência e não diretamente melhorar o desempenho e o aproveitamento escolar. Claro que diminuir a violência nas escolas e difundir a cultura da paz é fundamental não só para a educação, mas para a sociedade como um todo. Mas, se além de oferecer atividades esportivas e culturais, a escola proporcionasse espaços de conversa e reflexão para as famílias sobre assuntos relativos à educação, certamente seria uma oportunidade para esses familiares se comprometerem mais com a escolaridade dos filhos e não apenas com o espaço físico e social da escola.

Outra iniciativa concebida por uma grande rede de TV, nomeada de "Amigos da Escola", é um projeto "[...] implementado em parceria com o Fundo das Nações Unidas para a Infância (Unicef), Faça Parte, Conselho Nacional dos Secretários de Educação (Consed) e União Nacional dos Dirigentes Municipais de Educação (Undime), além de instituições e empresas comprometidas com a educação de qualidade para todos" (PROGRAMA AMIGOS DA ESCOLA http://amigosdaescola.globo.com). Nesse projeto, embora, também se compartilhe a ideia de que o acompanhamento da escolaridade pelos pais é fundamental para um bom desempenho escolar, a intenção é de que esses pais sejam colaboradores da escola e de suas atividades já programadas e não de oferecer espaços de discussão e de reflexão entre eles.

Projetos como esse podem, sem dúvida, aproximar as famílias da escola, mas na análise de Ribeiro (2006), como uma política de autofinanciamento das escolas públicas, podem reforçar a assimetria que já existe entre elas e até mesmo criar conflitos entre professores e pais. "Parece que o problema com a prática dos "Amigos da Escola" se inicia quando esse modelo de atuação passa a ser imposto de forma genérica a todos os pais da escola pública, tornando-se mais um motivo para discriminação daqueles que não podem ou não desejam cumpri-lo" (p. 392). 
As famílias das camadas desfavorecidas, como já foi visto, são as que mais sofrem com o preconceito dos educadores e com a tendência das escolas em responsabilizá-las pelo fracasso escolar dos filhos (PATTO, 1997). Muitas vezes são esses fatores que as afastam ainda mais da escola (GOMES, 2007; PAIXÃO, 2007; RIBEIRO, 2006). Apesar de documentos oficiais do governo também reconhecerem a importância da participação mais efetiva dos pais na escola para a melhoria da qualidade de ensino, os programas desenvolvidos nessa direção ainda são bastante tímidos, pontuais e não se caracterizam como um espaço de formação também para os pais. "Quanto melhor for a escola, quanto mais os pais ou responsáveis participarem e desejarem uma boa escola para seus filhos, melhor será o futuro da Nação, pois educação é um dos principais motores de desenvolvimento social e econômico da modernidade" (PACHECO, ARAÚJO, 2005, p. 20). Transformar esses princípios em políticas públicas mais abrangentes parece urgente.

\subsection{De volta ao início}

Agora cabe voltar às questões iniciais do trabalho para comentá-las: Qual o papel que a escola deve desempenhar junto às famílias? A escola é corresponsável pela educação integral das crianças e jovens, ou seja, compartilha com as famílias a tarefa de cuidar, socializar e desenvolver valores compatíveis com uma sociedade democrática e humanitária, e não apenas transmitir o saber sistematizado da humanidade. Como partilhar com as famílias a formação de crianças e jovens? A escola e seus educadores devem a princípio, compreender que não existe um modelo de família ideal e que as famílias reais são configuradas de inúmeras formas. Não são as configurações em si que determinam suas dinâmicas favoráveis ou desfavoráveis ao desenvolvimento dos filhos, mas inúmeros fatores psicossociais. Depois devem reconhecer que a capacidade de ser pai ou mãe não é dada com o nascimento dos filhos, mas é aprendida na relação com eles e na prática reflexiva sobre suas ações e seus sentimentos. E, por último, a escola deve procurar estabelecer com as famílias relações de reciprocidade e de simetria no que tange à sociabilidade e à formação de valores de seus alunos, e não impor prescrições para que elas sigam tal qual uma receita médica. 
Há um papel formativo também para as famílias? Sim, uma vez que se tornar pai ou mãe não é um fenômeno natural. A escola, seus educadores e outros pais podem ser parceiros adequados para os pais refletirem sobre questões que vivenciam com os filhos no dia-a-dia. Como deve ser desenvolvido esse papel formativo? Além de aprimorar as reuniões sistemáticas de pais, é preciso melhorar as formas de comunicação com as famílias e planejar atividades em que os alunos socializem, para seus pais e colegas, seus principais aprendizados no semestre ou no ano. Para isso, as escolas podem convidar os pais para encontros de discussão sobre suas relações com os filhos. Nesses encontros - não denominaria de reunião para que não se confundisse com as reuniões de pais já existentes - poderiam ser discutidos aspectos mais amplos da educação dos filhos, como entrada na adolescência, sexualidade, drogas, respeito às regras, etc. Não se trata de a escola ensinar os pais a serem pais, mas de proporcionar um espaço reflexivo em que eles possam se reconhecer e exercer seu papel de educadores com mais segurança e autonomia.

\begin{abstract}
A adoção de um modelo democrático, libertador, com novas práticas educativas, novas atitudes e sentimentos, traz a família para uma condição de instituição formadora, que pode ter uma ação no sentido de mudança social. A fim de que essa mudança ocorra, a família precisa ser vista como objeto de atenção educacional, especialmente as famílias das camadas sociais mais empobrecidas, cujas dificuldades na educação dos filhos remetem-se à sua condição de exclusão social e econômica (SZYMANSKI, 2000, p. 22).
\end{abstract}

Professores, orientadores e diretores de escolas já bastante atarefados com a realização diária de suas atividades, ao lerem este trabalho podem pensar "Mais uma função que a escola deve assumir!". A título de esclarecimento: a escola já assumiu parte da responsabilidade pela socialização e formação de valores de crianças e jovens, ou melhor, desde que existe ela exerceu essa função. Ter clareza sobre isso só facilita o trabalho educacional e pedagógico que a escola realiza com os alunos e suas famílias. Além disso, ela também já promove diversas das atividades sugeridas, como reunião de pais, mostra de trabalhos, festas, etc. Tratase de uma mudança de concepção na elaboração dessas atividades - devem ser pautadas por num caráter mais socializador e reflexivo, e não meramente informativo e expositivo. Nesse sentido, não se trata de atribuir mais 
responsabilidades à escola, mas de fornecer subsídios teóricos e práticos para que suas atividades já existentes sejam mais bem-sucedidas. Afinal, relações de reciprocidade exigem diálogo e corresponsabilidade.

\subsection{Considerações finais: as limitações do trabalho}

Como apresentado anteriormente, o presente trabalho de pesquisa empregou como instrumento de coleta de dados entrevistas parcialmente estruturadas e se propôs a fazer uma análise qualitativa do seu conteúdo. Sem dúvida as entrevistas permitiram que os pais participantes se aprofundassem em diversas questões sobre a relação família-escola e se constituíram, de fato, em espaços reflexivos e de troca. Entretanto, foram realizadas com um pequeno número de sujeitos - ao todo foram 13 entrevistas e 21 entrevistados, porque não só a entrevista, mas todo o trabalho posterior com elas (transcrição e resumo) exigem muito tempo de dedicação.

É importante reafirmar que pode ter havido um viés particular na seleção dos estabelecimentos de ensino, já que a pesquisa só foi autorizada em escolas em que a pesquisadora tinha contato pessoal com a direção e/ou coordenação. Assim, as escolas da nossa amostra, apesar das suas especificidades, tinham um perfil semelhante no que diz respeito às regras de convivência e também ao trabalho pedagógico voltado para uma formação mais ampla de seus alunos. Consequentemente, o perfil dos pais também se revelou semelhante quanto às expectativas em relação à educação escolar. A proposta inicial de ampliar o espectro cultural e de valores dos pais não foi possível ser realizada.

O trabalho ressente-se ainda de outra limitação: os participantes deveriam concordar em dar a entrevista, ou seja, deveriam ter disponibilidade para ela. Aqui vale mais uma vez lembrar que nem todos os pais contatados aceitaram participar ou autorizaram as escolas a fornecer seus telefones. Talvez esse procedimento tenha trazido mais um viés para a amostra: apenas os pais com afinidade sobre o tema ou que são mais preocupados e atentos à escolaridade e ao desenvolvimento dos filhos aceitaram participar. Mas essa é apenas uma hipótese que não poderá ser comprovada, uma vez que a falta de interesse em participar da pesquisa não foi objeto de estudo do presente trabalho. Também não seria coerente com as 
conclusões do trabalho afirmar que os que não aceitaram não estão atentos ou preocupados com a escolaridade dos filhos.

Embora tenha se buscado sistematizar os dados com coerência e rigor, levantando unidades temáticas comuns a todas as entrevistas, na abordagem qualitativa é impossível eliminar totalmente a subjetividade do pesquisador. Portanto, é possível que outros leitores reconheçam outras temáticas que não foram identificadas ou mesmo que não concordem com a sistematização dada neste trabalho. Afinal "a análise de dados qualitativos é um processo criativo que exige grande rigor intelectual e muita dedicação. Não exige uma forma melhor ou mais correta" (LÜDKE; ANDRÉ, 1986, p. 42). Entretanto, houve a preocupação de que os próprios entrevistados reconhecessem os dados principais levantados nas entrevistas e, por isso, foi-Ihes enviado um resumo de cada uma delas, que compõem o ANEXO C do presente trabalho.

Este estudo também teve um caráter exploratório, ou seja, não está pautado em num único referencial teórico, mas na contraposição dos dados com várias abordagens teóricas a respeito da família e da relação família-escola. Nesse sentido, outros estudos com outros métodos de pesquisa - que permita um número maior de participantes - ou com outra amostra de participantes - outras camadas sociais, outros perfis culturais dentro da mesma camada, por exemplo - serão muito bemvindos. Eles poderão complementar os dados do presente trabalho, assim como comprovar ou refutar algumas das hipóteses levantadas. Com certeza, para que família e escola formem uma parceria sólida e trabalhem juntas na educação integral de crianças e jovens ainda há muito a saber e fazer. 


\section{REFERÊNCIAS BIBLIOGRÁFICAS}

ADORNO, T.; HORKHEIMER, M. (1978). Família. Em: ADORNO, T.;

HORKHEIMER, M. (orgs). Temas básicos de sociologia. São Paulo: Cultrix.

ALMEIDA, L. de A.; BRANDINI, R.C.A.R. (2004). Em SZYMANSKI (orgs.) A Entrevista na pesquisa em educação: a prática reflexiva. Brasília: liberlivro.

ALTHUON,B.; ESSLE, C.; STOEBER, I. (2005). Reunião de pais sofrimento ou prazer?. São Paulo: Casa do Psicólogo.

AMIGOS DA ESCOLA [on line] [09-01-09]. Disponível em < http://amigosdaescola.globo.com > acessado em 09/01/09.

ARENDT, H. (1997). Crise na educação. Em Entre o passado e o futuro. São Paulo: Editora Perspectiva.

ARIĖS, P. (1981). História social da criança e da família. Rio de Janeiro: Editora LTC.

AUMENTA MATRÍCULA NA EDUCAÇÃO INFANTIL [on line]. Disponível em < HTTP://portal.mec.gov.br/index.php > acessado em 17/01/09.

BALL, S. (1995). Mercados Educacionais, escolha e classe social: o mercado como uma estratégia de classe. Em GENTILLI, P. (coord.). Pedagogia de exclusão. Petrópolis: vozes.

BALL, S.;GERWITZ, S.;BOWE, R. (1994). School choice, social class and distinction: the realization of social advantage in education. Londres: Centre for Educacional Studies. King's College. Relatório de pesquisa, mimeo.

BALLION, R. (1977). L'argent et l'ecole. Paris: Pernoud/Stock. 
BAUER, M. W.; GASKELL, G. (2003). Pesquisa qualitativa com texto, imagem e som: um manual prático. Petrópolis: Editora Vozes.

BERGAMASCO, D. (2007). Um em cada três jovens é filho de separados: na média geral da população, percentual é de um para quatro: pobres se separam mais que ricos. Folha de São Paulo, 7 de outubro de 2007, p.62. Caderno Família Brasileira.

BHERING,E.; BLATCHFORD,I. (1999). A relação escola-pais: um modelo de trocas e colaboração. Cadernos de Pesquisa, v.106, p.191-216

BOURDIEU, P. (2001). Os três estados do capital cultural. Em NOGUEIRA, M.;

CATANI, A. (orgs.) Escritos de educação. Petrópolis: Editora Vozes.

CAETANO, L. M. (2003). Relação escola e família: uma proposta de parceria.

Disponível em < WWW.unpec.com.br/revistaintellectus/-

arquivos/jul dez 03/pdf/luciana.pdf > Acessado em30/09/2007.

CARVALHO, M.E.P. (2000). Relações entre família e escola e suas implicações de gênero. Cadernos de Pesquisa,v.110, p.143-155.

CASTRO, C.M. (2004). A vovó na janela. Revista Veja, 10 de novembro de 2004, p. 20.

CHECHIA, V.A. Pais de alunos com sucesso e com insucesso escolar: percepções da escola, do desempenho escolar dos filhos e do desenvolvimento com o cotidiano escolar. Ribeirão Preto: Faculdade de Filosofia, Ciências e Letras de Ribeirão Preto, 2002. 284p. + anexos. Dissertação de mestrado.

COSTA, J. F. (2004). Introdução. Em Ordem médica e norma familiar. São Paulo: Graal.

DONATELLI, D. (2004). Quem me educa: a família e a escola diante da (in) disciplina. São Paulo: ARX. 
ENGUITA, M. F. (2004). Encontros e desencontros família-escola. Em Educar em tempos incertos. São Paulo: Artmed Editora.

ENEM (online). Disponível em http://www.enem.inep.gov.br/ acessado em 17/01/09.

FERRY, L. (2008). Famílias, amo vocês: política e vida privada na era da globalização. Rio de Janeiro: Objetiva.

FOURASTIÉ, J. (1972). Enquête sur la scolarité d'enfants appartenant à dês milieux favorisés. Analyse et Prévision, n1-2, juil-août.

. (1970). Une enquête sur la scolarité d'enfants d'instituteurs et de normaliens. Em Populacion et enseignement. Paris: PUF, p. 532-538.

FRAIMAN, L. P. A importância da participação dos pais na educação escolar. São Paulo: Instituto de Psicologia da Universidade de São Paulo, 1997. 134p. Dissertação de Mestrado.

FREIRE, P. (1996). Pedagogia da autonomia. Rio de Janeiro: Paz e Terra.

. (2002). Extensão ou comunicação? Rio de Janeiro: Paz e Terra.

. (1970). Pedagogia do oprimido. Rio de Janeiro: Paz e Terra.

GARCIA, H.H.G de O. Família e escola na educação infantil: um estudo sobre reunião de pais. São Paulo: Instituto de Psicologia da Universidade de São Paulo, 2005. 208p. Dissertação de mestrado.

GASONATO, M.R. de C. O sentido das expectativas das famílias em relação à escola para a formação de seus filhos. São Paulo: Pontifícia Universidade Católica, 2007. 106p. Dissertação de mestrado. 
GOMES,J. (2007). Relações família e escola - continuidade/descontinuidade no processo educativo. Disponível em <

WWW.crmariocovas.sp.gov.br/pdf/ideias 16 p084-092 c.pdf $>$ acessado em 30/09/2007.

GUIA ESCOLAS (2008). São Paulo: Educacional Marketing Editora.

HOBSBAWM, E. (1996). Revolução cultural. Em Era dos extremos: o breve século XX 1914-1991. São Paulo: Companhia das Letras.

IBGE (2007). Estatísticas do Registro Civil, v.34.

LAHIRE, B. (2004). Sucesso escolar nos meios populares: as razões do improvável. São Paulo: Editora Ática.

LASH, C. (1991). Patologistas sociais e a socialização da reprodução. Em Refúgio num mundo sem coração. Rio de Janeiro: Editora Paz e Terra.

LAVILLE, C.; DIONNE. J. (1999). A construção do saber: manual de metodologia da pesquisa em ciências humanas. Porto Alegre: Artes Médicas.

LOPEZ, J.S. (2002). Educação na escola e na família: o que é, como se faz. São Paulo: Edições Loyola.

LÜDKE, M.; ANDRÉ, D. A. (1988) Pesquisa em educação: abordagens qualitativas. São Paulo: EPU.

MACEDO,L. (2005). Apresentação. Em ALTHUON, B.; ESSLE, C.; STOEBER, I. Reunião de pais sofrimento ou prazer?. São Paulo: Casa do Psicólogo.

MARQUES, R. (2002). O envolvimento das famílias no processo educativo: Resultados de um estudo de caso em cinco países. Disponível em < HTTP://www.eses.pt/usr/ramiro/Texto.htm> Acessado em 07/05/2007. 
MARTINS; J.; BICUDO, M. A. V. (1989). Método de análise dos resultados. Em $\boldsymbol{A}$ pesquisa qualitativa em psicologia. São Paulo: Editora Moraes e EDUC - Editora da PUC- SP.

NOGUEIRA, M. A. (1991). Trajetórias escolares, estratégias culturais e classes sociais: notas em vista da construção do objeto de pesquisa. Teoria \& educação, v.3, p.89-112.

- (1995). Famílias de camadas médias e a escola: bases preliminares para um objeto em construção. Educação \& realidade, v.20 (1), p.9-25.

. (1998). A escolha do estabelecimento de ensino pelas famílias: a ação discreta da riqueza cultural. Revista brasileira de educação, v.7, p.42-56.

. (2004). Favorecimento econômico e excelência escolar: um mito em questão. Revista brasileira de educação,v. 26, p.133-144.

NOGUEIRA, M.A.; ROMANELLI, G.; ZAGO, N. (2003). Introdução. Em NOGUEIRA, M. A.; ROMANELLI, G.; ZAGO, N. (orgs.) Família e escola: trajetórias de escolarização em camadas médias e populares. Petrópolis: Editora Vozes.

OLIVEIRA, L. DE C. F. (2002). Escola e família numa rede de (dês) encontros: um estudo das representações de pais e professores. São Paulo: Editora e Livraria Universitária.

PACHECO, E.; ARAÚJO, C.H. (2005). Pesquisa nacional da educação: a escola pública na opinião dos pais: resumo técnico executivo. Disponível em < WWW.inep.gov.br/download/imprensa/2005/censoescolar/relatoriaqualidade.doc > acessado em 09/01/2009.

PAIXÃO, L. P. (2007). Escolarização: estratégias instrumentais e identitárias. Atos de pesquisa em educação, v.2, n.1, p.23-51.

PARO, P.H. (2000). Qualidade de ensino: a contribuição dos pais. São Paulo: Xamã. 
PATTO, M. H. (1997). A família pobre e a escola pública:anotações sobre um desencontro. Em: PATTO, M.H. (orgs.) Introdução à psicologia escolar. São Paulo: Casa do Psicólogo.

PEREIRA, C. (2008). Um plano para avançar. Revista Veja. 24 de dezembro de 2008, p.114.

PEREZ, M. C. A. Práticas educativas da família e da escola e seus efeitos no desempenho escolar de crianças das camadas populares. Ribeirão Preto: Faculdade de Filosofia, Ciências e Letras de Ribeirão Preto. (2004). 279p + anexos. Tese de doutorado.

PERRENOUD, P. (2001). A Pedagogia na escola das diferenças: fragmentos de uma sociologia do fracasso. Porto Alegre, Artmed.

PIAGET, J. (1991). Os pais têm, por prioridade, o direito de escolher o gênero de educação a dar a seus filhos. Em Para onde vai a educação. Rio de Janeiro: José Olympio Editora.

PINHEIRO, M. H. C. Relação família-escola e tarefas escolares nas séries iniciais do Ensino Fundamental. Ribeirão Preto: Faculdade de Filosofia, Ciências e Letras de Ribeirão Preto. (2007). 356p. + anexos. Dissertação de mestrado.

POLONIA, A C.; DESSEN, M.A (2005). Em busca de uma compreensão das relações família e escola. Psicologia escolar e educacional, v 9, n. 2, p.303 - 312.

PROGRAMA ESCOLA DA FAMÍLIA [on line] . [2008-12-22]. Disponível em < http://escoladafamilia.fde.sp.gov.br/apresentacao.htm > acessado em 09/01/2009.

RIBEIRO, D. F. (2006). A assimetria na relação entre família e escola pública. Paideia, v16, n. 35, p.385-394.

RIBEIRO, M.N.. Análise das relações entre família e escola na cidade de Porto Velho/RO. São Paulo: Instituto de Psicologia da Universidade de São Paulo, 2000. p. 133. Dissertação de mestrado. 
ROUDINESCO, E. (2003). A Família em desordem. Rio de Janeiro: Jorge Zahar Editor.

SÁ, V. (2001). A (não) participação dos pais: a eloqüência das ausências. Em VEIGA, I.P.A.; FONSECA, M. (orgs). Dimensões do projeto político pedagógico. Campinas: Editora Papirus.

SABINO, F. (2003). Reunião de mães. Em CARLOS DRUMMOND DE ANDRADE e outros Elenco de cronistas modernos. Rio de Janeiro: José Olympio Editora.

SCALZO, F. (1995). Má educação vem dos pais. Folha de São Paulo, Caderno Brasil, 26 de março de 1995, p.1-20.

SHORTER, E. (1975). A Formação da família moderna. Lisboa: Terramar.

SILVEIRA, L.M.O.B. (2003). A família, a escola e a (pós-) modernidade. Em GUARECHI,P. \& PEZZINATO,A. (Orgs) Psicologia em questão: reflexões sobre a contemporaneidade. Porto Alegre: EDIPUCRS.

SOUZA, B. P. (1997). Mães contemporâneas e a orientação dos filhos para a escola. Em: SOUZA, M.P.R. \& MACHADO, A M. (Orgs.) Psicologia escolar: em busca de novos rumos. São Paulo: Casa do Psicólogo.

SZYMANSKI, H. (2000). A família como um lócus educacional: perspectivas para um trabalho psicoeducacional. Revista brasileira de estudos pedagógicos, v. 81, n. 197 , p. 14-25.

Brasília: Editora Plano.

(2003). A relação família/ escola: desafios e perspectivas. 


\section{ANEXO A}

\section{Roteiro de questões:}

1) Há quanto tempo seus filhos estudam na escola....?

2) Por que escolheram esta escola?

3) O que veem de bom / e o que mais veem de bom nesta escola?

4) O que veem de ruim na escola?

5) Costumam participar das reuniões de pais? O que acham delas? Como se organizam para participar?

6) Participam de outros eventos que a escola organiza? O que acham deles?

7) Como acompanham o estudo de seus filhos?

Nas entrevistas com as mães separadas ou divorciadas, foi acrescentada a pergunta:

O que o pai acha da escola e como ele acompanha a escolaridade do(s) filhos(s)? 


\begin{abstract}
ANEXO B
Modelo de mensagem eletrônica enviado aos entrevistados para que opinassem sobre o resumo das entrevistas:
\end{abstract}

Vera,

Desculpe a demora, mas o trabalho de transcrever as entrevistas é grande. Segue anexo um resumo da conversa que tivemos no final de agosto. Por enquanto mantive os nomes reais, mas no trabalho final trocarei para fictícios. A ideia é que leia e veja se está fiel ao que conversamos. Pode sugerir alterações, inclusões ou exclusões. Para o trabalho final irá a versão que você aprovar. Por favor, mesmo que leve um tempo para ler, responda ao e-mail dizendo que recebeu o material.

Obrigada,

Luciana Fevorini

Modelo de resposta:

Luciana,

Desculpe-me pela demora na resposta. Seu email chegou quando eu estava fora do país e ficou perdido entre tantos outros. Estou de acordo com os termos do relato. Acho que vc pegou a essência das minhas ideias. Coloco-me à disposição para qualquer esclarecimento. abs Vera. 


\title{
ANEXO C \\ ENTREVISTAS - PRIMEIRA ESCOLA
}

\author{
Primeira Entrevista
}

$(28 / 02 / 08)$

A entrevista foi realizada com o casal, Sônia e Valter, no consultório da Sônia, que é psicanalista. Valter é empresário. Pedro, o filho único, cursa a $6^{a}$ série e está na atual escola desde a $5^{\mathrm{a}}$ série. Assim que apresentei os objetivos da entrevista e o objeto da minha pesquisa, também expliquei que iria gravar, transcrever e depois fazer um relato da nossa conversa. Quando esse material estivesse pronto, enviaria para eles por e-mail para que lessem e fizessem eventuais correções. É evidente que suas identidades seriam preservadas, mas, depois que o trabalho estivesse pronto, a escola teria acesso a ele. Ambos gostaram da possibilidade de poder ler o material e concordaram com a gravação.

Foi o filho quem quis mudar de escola no final do Ensino Fundamental I. Segundo o pai, estavam contentes com a antiga, mas Pedro demonstrou interesse em mudar especificamente para a que está agora. Talvez "por ele e pelo jeito dele e também pelo jeito que víamos a antiga escola", os pais acharam que seria bom Pedro ir para uma escola maior. Conforme coloca a mãe, Pedro tem um grande amigo cujos pais estudaram lá, o irmão mais novo já estudava lá, e ele "tinha esta espada na cabeça": ter de passar no teste na $5^{a}$ série. E Pedro, que o acompanhou em alguns eventos da escola, ficou maravilhado com o espaço físico e com as condições de prática de esportes.

Detalhe que acrescentam os pais: houve um movimento de saída da antiga escola por parte dos alunos da classe do filho. Eles atribuem a isso um manejo inadequado da professora da $4^{a}$ série. As crianças tinham uma ideia de que "a $5^{a}$ série era de gente grande, que portanto tinham de ter uma escola grande, e que aquela era muito pequena para eles". "Era uma coisa do universo deles", diz o pai. Sem dúvida, a atual escola foi uma "conquista" do filho, que, sem cursinho preparatório, conseguiu 
se sair bem. Receosos de que o filho não conseguisse entrar, porque é uma escola muito concorrida, os pais apresentaram uma alternativa ao filho: uma escola perto de onde moram da qual gostaram muito da proposta. "Ser perto de casa é uma facilidade, mas não resolve nada. O fato é que gostamos muito". Justamente porque sabiam que era difícil o teste para ingressar na escola, não queriam gerar pressão nenhuma sobre ele.

Tanto a mãe quanto o pai tiveram amigos que estudaram nesta escola e a consideravam muito interessante. Na sua época de colegial, continua a mãe, ela achava esta escola "o máximo" e, portanto, também não estavam indiferentes diante da possibilidade de o filho estudar lá. Na verdade, explica o pai, em termos de expectativa talvez as deles não fossem menores do que as de Pedro. O fato de ele ter entrado foi motivo de alegria e orgulho tanto para o filho quanto para eles. "Se eu pudesse ter escolhido o colégio em que estudei, a minha primeira opção teria sido esta", reforça o pai.

"E como foi a adaptação do filho a uma escola tão grande e diferente da anterior?"

"Na primeira semana foi pura empolgação, depois Pedro começou a enfrentar situações que "não tinha no repertório dele", diz a mãe. De uma criança muito conhecida e querida na antiga escola, ele passou a ser "um Zé ninguém" ou "pior que isso": virou motivo de brincadeira de meninos que não conhecia. Quando iam buscá-lo, Pedro contava situações difíceis da convivência com outros alunos. Ao perceberem essa dificuldade, foram conversando com ele, e a mãe procurou a orientadora, pedindo "um socorro". Ela a tranqüilizou, dizendo que ele não demonstrava, na escola, que estava deslocado ou que sentia falta de acolhimento.

Segundo o pai, a adaptação deve ser dividida em dois aspectos. Do ponto de vista do desempenho escolar, Pedro parece não ter sentido nenhuma diferença. Já do ponto de vista do relacionamento dele com a escola e com as pessoas foi mais complicado. Os pais tinham receio de perder, com a troca de escola, uma supervisão bem individualizada que julgavam importante no processo de desenvolvimento do filho. Entretanto, surpreenderam-se. Apesar de grande, esse olhar mais individualizado a escola nova também tem. Ouviram da atual orientadora descrições do Pedro que "combinavam exatamente" com que conhecem dele em casa. Mesmo com muitos alunos, há uma estrutura em que o contato individual não 
só se mantém como tem a mesma intensidade da outra escola. Perceber isso os confortou, favoreceu "a adaptação deles", brincou a mãe.

"Além do olhar individualizado, o que mais veem de bom na atual escola?"

Os esportes. A possibilidade de o filho escolher vários de que goste e poder praticar lá mesmo é o primeiro ponto positivo levantado pela mãe. Depois, o fato de ter vários professores, embora essa seja uma característica do Ensino Fundamental II e não específica desta escola, porque favorece "transferências múltiplas". Os professores lhes parecem muito bons, especialmente a professora de português, que Ihes causou muito boa impressão. No começo Pedro teve dificuldade com o trabalho em grupo, prática desta escola, talvez do ciclo, na qual ele não tinha muita experiência e, por não saber exatamente como fazer, enfrentou problemas na execução, na avaliação e no relacionamento com os colegas. Entretanto, em função da boa condução da professora e dele próprio acabou terminando tudo bem.

Na sua reposta, Valter diz que um dos "fetiches" do Pedro querer tanto ir para a atual escola era o futebol. Como era considerado bom na antiga escola, achava que fazer futebol na atual seria o máximo "porque tinha até campo!". Mas quando chegou, percebeu que havia muitos garotos muito melhores do que ele, o que o deixou angustiado e frustrado. Surpreendentemente, segundo o pai "ele olhou para outro esporte, gostou, se envolveu, passou a jogar e se saiu bem". O pai não sabe o quanto essa postura de superar uma frustração e buscar outras possibilidades é fruto do próprio amadurecimento do filho ou das ferramentas que a escola oferece, mas considera esse episódio representativo do que tem sido esta escola para Pedro.

O fato de ser filho único, observa a mãe, por mais que ela e o pai se cuidem, faz com que depositem muitas expectativas nele, o que talvez o tenha deixado muito auto-crítico e exigente consigo mesmo. Com certeza a situação que Pedro enfrentou no futebol foi interessante porque não foi uma desistência, mas uma percepção de que o seu futebol "não dava", o que o motivou a buscar outra saída. Inclusive, hoje Pedro está treinando outro esporte num clube. "Parece que ele desenha bem o que quer lá na frente", diz o pai, mas esse mérito não atribui apenas à escola, mas também ao ambiente de casa. 
Quando pergunto se veem algum problema ou coisas ruins na escola, mãe e pai ficam um pouco em silêncio. Depois a mãe começa dizendo que o contato que tem com a escola já foi muito maior. Contudo, um aspecto positivo, a proposta de uma "linha mestra comum", é levantado por ela. Fica um pouco reticente, dizendo que não vê nada de ruim e só depois aponta uma crítica que nomeou de "burocrática": o horário dos esportes, pois as crianças têm apenas vinte minutos de intervalo entre o fim das aulas e o começo dos treinos. O pai complementa dizendo que se alimentar e ter tempo para a digestão é fundamental para treinar bem. E a mãe acrescenta ainda que esse pouco tempo dá uma sensação de que as crianças já têm uma "vida de executivo". O pai considera que essa é uma questão menor, mas que deve ser levada para a escola.

Valter comenta que estava pensando que o relacionamento deles com a escola agora é muito mais tênue. Na antiga, frequentemente ele entrava para buscar o filho; agora, se entrar, acha que o filho pode até "bater" nele. E a própria escola reserva esse espaço para os alunos. Sônia reforça dizendo que "tem a catraca lá". Na antiga escola, segundo Valter, "levou um bom tempo para sentirmos incômodo com algumas coisas". E, em função de o Pedro estar na atual há pouco mais de um ano, ele acha que "estão em lua de mel" com a escola. Imagina que deve ter defeitos, sim, mas eles ainda não estão conseguindo enxergá-los. Sempre participam dos eventos pedagógicos da escola; dos sociais, não. Segundo Sônia, Valter gosta de participar das reuniões, é "superatuante".

"O que acham das reuniões de pais?"

Rapidamente o pai responde que "são chatas", e a mãe concorda "porque são muito longas". Não que não gostem dos assuntos tratados; pelo contrário, ficam muito fascinados com as propostas de ensino e com a metodologia desenvolvida, "gostam dessas conversas". Mas acham que elas acabam se estendendo muito.

Dizem que há uma diferença importante entre as reuniões da atual escola e as da anterior, que, segundo a mãe, também eram chatas. Enquanto na atual elas são excessivamente expositivas e formais, sem permitir a participação ou o aprofundamento de algumas questões, na antiga, exatamente por serem mais interativas, favoreciam a colocação de questões extremamente individuais e pessoais de outros pais. O pai diz que essa "interface" é complicada. Se não tiver 
muito interesse, não dá para ficar. É possível que não seja fácil para a escola também, mas não veem muita saída. Numa reunião menor, só com pais dos alunos novos, Sônia ficou muito incomodada com a qualidade das perguntas dos outros pais. Até brincou com uma mãe do lado dizendo que não só as crianças deveriam passar por uma seleção, mas os pais também. Enfim, preferem os contatos individuais.

"Como acompanham os estudos do filho?"

Pedro faz sozinho as lições, embora a mãe fique monitorando-o pelo telefone. Às vezes ele pede ajuda e, então, "é muito tenso", porque na verdade ele não quer muito ser ajudado. Se ela não entende imediatamente uma questão e ele tem de ter um trabalho para explicá-la, ele se irrita. "Talvez seja a questão da auto-exigência, mas também uma falta de vontade de fazer", considera o pai. E tem mais: ele não sabe se a falta de vontade é genuína ou se é a "moda". Os pais observam, pelos amigos do filho, que "é a moda não gostar da escola, da aula, do professor, etc".

Para a mãe o filho faz as lições muito rapidamente e quase não estuda para as provas. Ela esperava que na atual escola ele tivesse de se disciplinar mais em relação ao estudo, mas isso não aconteceu. Então fica insegura porque imagina que em algum momento "esse jeito" não dará conta. Já o pai pensa diferente: considera "sorte" o fato de o filho não estudar muito e assim mesmo ter boas notas. Pergunto a quem o filho recorre mais quando precisa de ajuda, e o pai responde que "é setorizado", pois Pedro procura a ambos conforme o assunto, mas em geral procura mais a mãe.

É evidente que, como Pedro é um bom aluno, eles não têm experiência de serem chamados na escola por problemas de nota ou de comportamento. Os pais afirmam que nesse aspecto Pedro é um filho exemplar: "Nós somos..., lógico, todo pai é babão... Mas o Pedro ajuda a gente, é boa pessoa". 


\section{Segunda Entrevista}

$(12 / 03 / 08)$

Esta entrevista foi realizada com o casal Betina e Jean, na residência deles. Com dois filhos na mesma escola desde a Educação Infantil, um na $5^{\mathrm{a}}$ série e outro no $1^{\circ}$ ano, ela é jornalista freelancer e ele trabalha com publicidade e é filósofo autodidata. Evidentemente explico meus objetivos, meu objeto de estudo, assim como todo o procedimento que realizarei posteriormente com o material. Só começo a gravar depois da autorização de ambos.

Julie estuda na atual escola desde a $1^{\text {a }}$ série. "Por que a escolheram?", pergunto. A primeira escola que ela frequentou foi "uma bastante alternativa", uma Waldorf. Embora não tivessem uma identidade particular com a pedagogia dessa escola, segundo o pai, as outras que foram conhecer lhes pareceram "sem graça" e, segundo a mãe, "mais que sem graça, [...] muito utilitaristas", que se propunham a preparar a criança para o futuro. E a "Waldorf não preparava a criança para nada, só acolhia,deixava brincar e ficar com as outras crianças", o que thes pareceu ideal para uma criança pequena. Contudo, foi justamente Julie que passou a se interessar por letras e números, e aí a Waldorf não se mostrou mais interessante, pois só iniciava a alfabetização aos sete anos. Como também não eram antroposóficos, procuraram uma escola mais convencional.

Primeiro foram em busca de uma escola francesa, porque o pai é francês e seu filho mais velho, de outro casamento, estudou lá. Mas a mãe não gostou, pois a escola Ihe pareceu muito rígida em termos de disciplina e comportamento. Pensaram, então, na atual escola em que a filha está hoje porque conheciam pessoas que estudaram ou trabalhavam lá e viam que eram "curiosas [...] que achavam aprender legal" e eram voltadas para o lado humano. Obviamente a filha, vindo da Waldorf, não passou no teste para ingressar na escola. No entanto, os pais ficaram muito bem impressionados com a devolutiva dada pela escola, na qual foi feita uma descrição perfeita da filha.

Seguindo diversas sugestões e indicações, acabaram matriculando Julie numa escola que tinha continuidade no Ensino Fundamental e Médio, na qual ela ficou por 
dois anos. Essa escola, "mais parecida com eles", iniciou um bom trabalho de alfabetização, unia o aprendizado com o lúdico e também tinha um interesse pela área de humanas. Só que, segundo o pai, "era uma escola muito cheia de perguntas a não se fazer [...] e Ihe faltava repostas". Apesar de trabalharem muito bem os conteúdos, pareceu-lhes que a escola tinha dificuldade ou não achava importante dizer para a criança "agora chega". Inclusive os próprios amigos da filha eram crianças que não estavam acostumadas a ouvir "pára!". Perceberam que estavam em desacordo com a escola e com os outros pais e decidiram inscrever a filha mais uma vez para o teste da atual escola. Justamente porque esta lhes pareceu que sabia mais colocar limites para os alunos, unindo a qualidade pedagógica à disciplina "sem questões existenciais dramáticas, [...] eram mais seguros de si". 0 que seriam essas questões existenciais? A forma de lidar com as crianças.

Dessa vez Julie passou no teste sem problemas. O que conheciam da nova escola, repetiram, eram ex-alunos ou professores que tinham em comum a consciência, a inteligência, a crítica, mas também valores humanos advindos, talvez, da sua origem religiosa. "Isso tudo configurava um conjunto interessante". O único aspecto negativo, segundo o pai, que foram perceber só depois de algum tempo, é que outros pais veem a escola de maneira bastante utilitária, classista e elitista, "um lugar onde as filhas vão encontrar maridos ricos e os filhos vão encontrar bons parceiros de negócios". Já ouviram isso literalmente "da boca de pais, sem o menor pudor", complementa a mãe. Contudo, eles não identificam esse valor "classista e elitista" na escola. Sem dúvida esse é um aspecto que os preocupa e que devem observar atentamente, embora, segundo o pai, seja uma "tendência das boas escolas em países pobres" estabelecerem uma relação "endêmica de classes".

Jean sai para buscar o filho mais novo na escola e a entrevista continua só com a mãe. Pergunto: "O que vê de bom na escola?". Ela diz que os professores são muito bem formados e interessados em trabalhar a própria formação, "continuam a se interrogar [...], e não têm uma fórmula pronta que estão aplicando há um tempão". Detalhe: breve silêncio e confirma que o melhor da escola é a qualidade dos professores. Não que sejam muito inovadores, mas fazem bem feito aquilo a que se propõem. O que tem de ruim? "Saem muito pouco daquilo". Impressionante como "eles não saem da escola, [...] é muito pouco criativa nas propostas [...]. São bons, mas parece que têm medo de ousar um pouco". "Talvez pelo próprio público, por 
serem crianças filhas de pessoas importantes, a escola tenha medo de sair com elas", é a opinião da mãe.

"Há mais alguma crítica?". Sim, disse, mas em situações específicas e pontuais. Uma vez houve problemas com uma professora da primeira série da Julie, mas a situação toda foi muito bem conduzida pela orientadora. De fato, em nenhum momento ela foi "corporativista, defendeu a professora ou colocou em dúvida o que a filha estava falando. Ouviu-nos "muito" e fez muito bem esse triângulo", o que lhes deu uma segurança muito grande. Também houve outra situação com a professora do filho mais novo e, mais uma vez, a acolhida da escola foi muito boa, tanto da professora quanto da orientadora. A receptividade, a troca, é muito grande. Até hoje foram muito bem recebidos em todas as suas queixas. No entanto, nunca chegaram a levar para a escola a questão da pouca ousadia e das poucas saídas. Acharam que talvez fosse interessante levar, pois "exploram muito bem os livros", mas eles esperavam que a escola explorasse também "o mundo fora do livro." É evidente que é difícil ter tudo. A escola oferece um "pacote" e, para a Julie, que é muito estudiosa e interessada, parece estar sendo bom, continua a mãe.

"Participam dos eventos que a escola organiza?" Ela e o marido vão em todos, "são superparticipativos". Raramente veem juntos pai e mãe das outras crianças nas reuniões. É "engraçado", pois, em geral, vai só a mãe, sejam casados ou separados, "os homens não vão às reuniões! [...] Parece que a escola não é lugar de homem adulto". Seu marido é "superparticipativo"; aliás, organizaram a vida para ficarem perto um do outro e perto dos filhos, de tal modo que fazem algumas coisas que "hoje em dia são meio raras", como almoçar e jantar juntos.

Embora compareçam em todas as reuniões de pais, acham que não é possível acompanhar muito bem, por meio delas, o que está acontecendo na escola. A mãe já tinha ouvido um relato de que na $5^{a}$ série a escola "expulsa os pais", e ela tem sentido isso mesmo. "Este ano está esquisito". Embora ache que de agora em diante deva ser assim mesmo, "tem de quebrar a porta para entrar ou então ter algum problema específico a tratar". A reunião de pais coletiva é muito formal, focada em procedimentos, e em geral só a escola fala e fala de uma maneira muito distante do que já foi feito. E a mãe acha isso ruim, porque, se a escola explicasse melhor o que vai trabalhar, os pais poderiam ficar mais atentos às tarefas dos filhos, contribuiriam 
mais, principalmente se o filho não costuma falar do que acontece na escola, como é o caso dos filhos deles.

A escola faz apresentações de trabalhos dos alunos, mas também são muito formais. "Eles fazem lá uma micagem", disse a mãe. Tirando o conteúdo que é muito interessante, a mãe considera a escola uma instituição "extremamente formal" ainda, que lembra muito a escola em que estudou, "em termos do jeito que se coloca para os alunos e para os pais [...]. Se o pai quebrar isso, é bem recebido, senão fica distante mesmo". Ela também participa dos eventos sociais da escola mais do que o marido. Ajuda em barracas porque "acha divertido".

Enquanto o filho mais novo faz a lição do lado dela até hoje, Julie "os está excluindo". Daqui a pouco vai ter de procurar a escola e perguntar se é assim mesmo, se deve insistir em tentar saber o que está acontecendo ou não. Não que a filha necessite de acompanhamento nas lições, mas os pais querem acompanhar porque gostam de saber o que ela está aprendendo. Em matemática, sim, Julie precisa de ajuda porque se não acaba "rateando", tanto que o pai passou uns exercícios extras para ela.

Como a $5^{\text {a }}$ série tem uma rotina bem diferente daquela que estava habituada, no começo Julie "estava completamente perdida, [...] não sabia lidar com o fato de que as matérias são pingadas". Ao perceberem isso, deram-lhe dicas de como podia se organizar melhor com as tarefas e logo ela ficou mais tranquila, tanto que obteve um bom conceito em organização. Mas, apesar de todas as diferenças, parece que a filha está se adaptando bem ao Ensino Fundamental II, que "é mais cansativo e a organização é mais complicada". Já houve várias avaliações e ela teve bons resultados, com exceção de matemática. Entretanto, Betina está sentindo falta de uma reunião de pais para se inteirarem mais do que está acontecendo. Se não for marcada em breve, ela própria vai agendar uma.

De uma maneira geral Julie está gostando muito da $5^{a}$ série, porque tem mais liberdade e a relação com os professores é um pouco mais solta, menos formal. Ela está bem também em termos de sociabilidade, pois, apesar de não ter ficado na classe com nenhum colega mais próximo, Julie já fez novas amizades. De fato, para Betina há um lado bom e um lado ruim de estudar sempre na mesma escola. $\mathrm{E}$ o que vê de ruim é que um mesmo grupo varia um pouco a configuração, mas não 
muda essencialmente. Gostaria que a filha tivesse relações sociais mais amplas, não só com meninos e meninas mais ou menos como ela. Neste ano há a possibilidade de a Julie participar de um trabalho voluntário numa favela. Mas a mãe também acha que não é isso que proporcionaria a diversidade nas relações de amizade da filha.

Antes de começar a gravação, quando expliquei sobre o objeto do meu trabalho, Betina comentou que encontrou no cinema muitos alunos da escola da filha, sozinhos, assistindo ao mesmo filme que ela e fazendo muita bagunça. Até os seguranças tiveram de intervir. Agora retomo a questão, o pai chega da escola com o filho mais novo e a entrevista sofre uma breve interrupção. Tão logo Betina explica que ela e o marido foram assistir Juno, um filme que trata da gravidez na adolescência, "onde tudo parece muito fácil: a relação com os familiares, com os amigos, etc. [...] e como fica essa situação para uma criança de dez, onze anos que está assistindo a isso sozinha?". Ela e o marido ficaram se perguntando se os pais sabiam a qual filme os filhos estavam assistindo, porque é um filme que "precisaria de um diálogo com um adulto." Na verdade, tinham quase certeza de que os pais daquelas crianças não sabiam ao que elas haviam ido assistir.

Ela imagina que a escola deve ter de lidar com situações como essa, em que os pais ficam muito ausentes do dia-a-dia das crianças. O que observa são crianças que "passam da escola para a babá e da babá para a escola". Detalhe: na turma de amigos da Julie, tem muitos casais se separando. Na turma do mais novo, isso tem acontecido menos e frequentemente os casais vão juntos às reuniões, mais até do que quando a filha estava na pré-escola. De fato, para Betina essas separações fazem com que as crianças sejam "vítimas dos pais legais [...] nenhum dos dois quer ser o chato". Já Jean aponta que não são só os pais separados que agem dessa maneira, mas alguns casais tratam os filhos como "o imperador da casa [...] a mãe e o pai acabam sendo serviçais do garoto". Além do fenômeno das separações, segundo Betina, alguns pais também vivem uma "voracidade profissional", e a ideia de perseguir uma carreira acaba deixando as crianças como "uma atividade a ser cumprida e se dá para passar para outro, legal".

Conforme o pai há dois tipos de família na escola: "os amantes da grife e os amantes do conhecimento". Para ele esse é um problema de qualquer escola paga. 
"Pena que o ensino público esteja tão deteriorado, inclusive na França, porque o filho poder estudar com hiper-ricos e também hiperpobres traz uma diversidade muito bacana".

Como é Jean quem estuda matemática com a filha, pergunto como se dá esse acompanhamento. De fato, ele tem percebido alguma dificuldade em Julie, mas mais por falta de atenção do que de compreensão. Então tem estudado um pouco com ela. Não só eles não têm experiência de serem chamados na escola por problemas de nota ou comportamento, como, quando vão lá, só recebem elogios pela filha, "quase como a aluna perfeita", justo por não ser "CDF quietinha, mas questionadora e desafiadora", complementa a mãe.

Terminada a entrevista, foi a vez de Jean e Betina me entrevistarem. Primeiro me perguntaram por que eu estava fazendo esta pesquisa e se eu era teórica ou trabalhava com educação. Quando respondi que sou orientadora e o nome da escola em que eu trabalho, demonstraram certa satisfação e surpresa por eu não ser apenas uma teórica e porque conhecem a escola em que trabalho. Até se perguntaram por que não pensaram nela como uma possibilidade para os filhos. Em seguida me perguntaram como está a "minha" escola e também minha opinião sobre a escola dos filhos deles. Também quiseram saber mais sobre a pesquisa, quais outras escolas participariam, quais os critérios de seleção, etc. Conversa vai, conversa vem, acabamos discorrendo sobre alguns dos problemas da educação no nosso país.

Terceira Entrevista

$(18 / 03 / 08)$

A entrevista foi realizada com o casal Mônica e Marcos no escritório de advocacia de ambos. Eles têm dois filhos: Guilherme, na oitava série, e Heitor, na sexta, que estudam na mesma escola desde a Educação Infantil. Assim que expliquei meus objetivos e procedimentos de trabalho com a entrevista, os pais autorizaram a gravação e iniciamos a conversa. "Por que escolheram a atual escola?", perguntei. 
O pai respondeu que a Mônica é ex-aluna da escola, que também era bem "conceituada na época". A mãe fez questão de que os filhos estudassem lá e ele não se opôs, pois "era uma boa escola". Já a mãe disse que "adora" a escola, estudou lá por apenas três anos, mas gostou muito.

Então pergunto se não chegaram a pensar em outras possibilidades. Quando o filho mais velho ia entrar na escola, segundo o pai, eles conversaram com várias pessoas amigas e também com psicólogos e pedagogos, e "esta atendia mais às necessidades deles", mostrou-se mais "conveniente" pelo fato de a mãe ter estudado lá e também por ser perto de onde moram. Inclusive o pai se lembra de que consultaram uma pedagoga para saber se o filho devia refazer o pré ou ir para a $1^{a}$ série, porque é de setembro e estava um pouco adiantado. Essa profissional recomendou que refizesse um ano de pré em função de aspectos emocionais, não intelectuais, e também indicou a atual escola. Caso o filho não passasse na seleção, a mãe disse que tinha uma segunda opção de que tinha gostado muito. Mas a preferência dela sempre foi pela escola em que estudou.

"Por que quis que os filhos estudassem na mesma escola que você?" Antes ela havia estudado numa pequena escola de bairro, preparado-se no cursinho para entrar e gostado muito. Sempre observou que as pessoas do colégio tinham uma formação muito boa como cidadãos, um conhecimento geral, uma autonomia. Não só os professores eram "excelentes", mas a maioria das pessoas que se forma lá é bem-sucedida nas mais diversas áreas. "É um colégio em que se ensina a criança a ser crítica, não aceitar por aceitar". Pergunto para o pai se ele não teve o mesmo sentimento pelo colégio em que estudou. "Não", respondeu. Além disso, a escola era mais distante da residência deles. Como a esposa, ele também havia estudado numa escola pequena até a $7^{a}$ série e depois é que foi para outra maior. Tem boas recordações, acha que as duas são boas. Mas, como tiveram mais informações sobre a ex-escola da esposa, optaram por ela.

Além disso, segundo Marcos, a escola em que estudou é laica e não tem ensino religioso, que considera muito importante. Por isso também optaram por uma que tivesse a mesma orientação religiosa que eles. $E$ a escola incentiva um trabalho com comunidades carentes, motiva os alunos a terem esse tipo de atuação, "o que depois pode se tornar espontâneo", ressalta a mãe. Mais um aspecto positivo é 
apontado pela mãe: em termos de ensino, "conseguem pinçar a realidade no que estão aprendendo", fazendo assim um trabalho mais interdisciplinar, bem diferente de quando estudou em tinha que memorizar os conteúdos. Enfim, os dois filhos gostam muito da escola.

Ocorre que o filho mais novo, Heitor, passou a ter problemas de aproveitamento. Logo procuraram uma psicopedagoga, que sugeriu que ele estudasse numa escola menor, "em que houvesse uma atenção maior para ele". Mas houve uma resistência grande da mãe em mudá-lo. O pai também não queria, mas mais em função de problemas de logística, pois seria mais complicado levar e buscar os filhos em lugares diferentes. A mãe realmente não gostou dessa indicação, "ficou armada". Depois a própria psicopedagoga foi ao colégio e acabou se surpreendendo, porque, apesar de ser uma escola grande, conseguiram desenvolver um trabalho individualizado com o aluno, atendendo às necessidades de Heitor. Houve um acompanhamento quase como se fosse uma escola com poucos alunos.

Mesmo com todo o suporte dado, não houve a solução do problema. "Foi como se fosse um remédio para dor de cabeça: tomou, a dor passou, mas a dificuldade continuou", disse o pai. Talvez a psicopedagoga tenha tido razão, na visão dele, e o melhor para Heitor seja mesmo outro tipo de escola. A que está "não é a ideal", porque ele tem problemas de atenção, "se dispersa com muita facilidade". Explica que, no ano passado, além do trabalho de psicopedagogia, o filho teve o acompanhamento de uma "tutora", por indicação do colégio. O fato é que "pagou mais um colégio" de apoio "ao passo que, se tivesse num outro, talvez só pagasse o colégio mesmo". Justamente "é um problema nosso não ter tirado ele ainda". Claro que o filho passa de ano, "mas tem que ficar correndo atrás" e por causa de outras características, que não as pedagógicas, é que ainda permanece.

Antes de a escola alertá-los sobre os problemas de aprendizagem do filho, a mãe já observava que Heitor era disperso. Sempre acompanhou seus estudos, fazendo junto com ele as lições, o que a deixava muito cansada. Mas não foi só a própria observação deles, segundo o pai, que os fez buscar apoio psicopedagógico. Também foram chamados pelo colégio por causa de notas baixas e foi naquele momento que iniciaram o trabalho com a psicopedagoga depois de um psicodiagnóstico completo. Entretanto, a mãe ressalta que independente disso ela 
própria observava as dificuldades do filho. "Desde quando?" Recapitularam e identificaram que desde a $4^{\mathrm{a}}$ série. Inclusive era para o trabalho psicopedagógico ser interrompido na $5^{\mathrm{a}}$, mas continuou. Agora "ele teve alta".

Exatamente nessa época, de acordo com o pai, fizeram teste de QI no filho e "deu tudo certo". Ele apenas se dispersa com muita facilidade. Enquanto a mãe diz que o QI de Heitor é acima da média, o pai diz que "é normal". Mas ela insiste, dizendo que é acima da média, igual ao do filho mais velho. Só que, enquanto o Guilherme é superconcentrado, faz as lições e nunca dá trabalho, Heitor é dispersivo e deixa sempre as tarefas para depois. Segundo a Mônica, desde antes da primeira série ela observava a falta de concentração do filho. Até chegou a pedir que a escola o mantivesse no pré, embora ele não seja do segundo semestre como o irmão. Entretanto, nem a escola, nem o pai, nem psiquiatras e terapeutas que consultaram acharam que seria uma boa medida. "Já sofri muito com este problema", disse Mônica. E Marcos continua dizendo que continuam sofrendo, pois o problema não se resolveu.

"Como é o trabalho de tutoria?" Enquanto a psicopedagoga enfatizava a organização, como trabalhar a agenda, etc. no consultório dela, a tutora estudava com ele em casa, pois sabia todas as matérias e também acabava colaborando na organização da casa, como a arrumação do quarto, da mesa, elaborando um quadro de atividades da semana, etc.. Além desses dois trabalhos, a escola também oferece um apoio para os alunos com dificuldade depois da aula. Então, durante algum tempo, Heitor participava do apoio, ia às sessões de psicopedagogia e ainda recebia a tutora em casa, ficando muito sobrecarregado. O apoio não é pago, mas o trabalho de tutoria, sim.

Segundo Marcos, tudo isso "não adiantou", e Mônica complementou dizendo que "Heitor ainda não tem autonomia para estudar". Tinham acabado de receber a notícia de que a tutora não ia mais continuar o trabalho porque havia sido contratada pela escola, o que "foi um susto" para a mãe. "Inclusive", continua o pai, "estamos contratando outra, ou seja, o problema não se resolveu, a escola continua não sendo adequada, mas nós, pais, continuamos insistindo. Estou consciente disso: esta não é a escola para o meu filho. Pago duas e me queixo". Não que a escola continue avaliando como necessário o trabalho de tutoria; são eles que acham isso, 
embora neste ano Heitor ainda não tenha sido convidado para fazer o apoio. Detalhe: o pai expressa dúvida se o filho vai conseguir ter autonomia para estudar, porque "é desorganizado, é bagunceiro com as coisas dele".

O trabalho de apoio é apontado pelo pai como um aspecto negativo da escola. Apesar de achar ótima a possibilidade de os alunos tirarem as dúvidas durante o ano, antes da recuperação, os pais julgam que, em função das características do filho, esse trabalho não tem sido eficiente. "Será que dá resultado para os outros alunos? É problema do nosso filho?" Marcos não sabe exatamente como são as aulas de apoio, mas acha que deveriam ser "mais próximo", não sabe quantos alunos tem, mas acha que "deveria ser um trabalho mais pessoal, ter menos alunos por professores". Segundo Mônica, tem bem menos alunos no apoio do que em sala de aula, mas eles nunca esclareceram essa questão específica na escola. Também não há uma avaliação do aluno no apoio, o que é outro ponto negativo, segundo eles, porque ficam sem saber qual é o resultado do filho especificamente nesse trabalho.

É a mãe quem vai às reuniões. Mas quando é a escola que chama, o pai também comparece. Nas reuniões gerais "é a mesma coisa", segundo Marcos. Como sua esposa prefere participar, considera que não é preciso irem os dois; depois podem trocar informações. É óbvio que poderiam inverter os papéis, mas fazem assim porque é ela quem tem mais contato com o colégio. "Como avalia as reuniões?". "Elas são muito gerais e bem no superficial", disse a mãe. Neste ano não puderam comparecer à reunião do filho mais velho e, por isso, ela pretende marcar reuniões individuais com os orientadores dos dois filhos, do mais velho para se informar do que aconteceu na reunião e do mais novo para ter retorno das avaliações diagnósticas que os professores fazem todo início de ano. Apesar de aproveitar mais os contatos individuais, ela gosta das reuniões gerais. Acredita que mesmo se não houvesse problemas, seria importante que a escola os informasse sobre como os filhos estão se desenvolvendo. Mas a mãe não sabe como a escola poderia fazer isso com tantos alunos. Por outro lado, sentem que a escola é sempre muito disponível para atender às solicitações dos pais. Contudo, há pais que reclamam. No ano passado alguns questionaram a escolha do livro de leitura indicado, chegando a dizer que não autorizavam os filhos a lerem. Porém, ambos pensam diferente: não devem questionar esse tipo de escolha da escola, porque não deve 
ser "à toa". Também participam da festa junina, ajudando nas barracas e fazendo doações. "É evidente que os filhos gostam dessa participação", ressalta o pai. "Se orgulham disso", complementa a mãe.

Heitor não reconhece as próprias dificuldades. Para ele, o problema é dos professores, que não explicam direito ou são chatos. Justamente por deixar tudo para a última hora, ele se desespera e a mãe acaba auxiliando-o nas tarefas. "Será que vale a pena tudo isso?", se pergunta Mônica. Por outro lado, ela continua, observa que o aluno médio que consegue superar essas dificuldades "chega no futuro ele consegue se dar bem na vida". E por isso a insistência. "Mas dá um aperto... O Marcos acho que consegue ser mais frio, mais racional." Como são ausentes em casa, segundo o pai, os filhos acabam passando o dia com a empregada, que não foi contratada para monitorá-los e nem tem capacidade para isso, e "ficam muito soltos".

Para poder ensinar o filho, mãe conta que aprendeu muita coisa de matemática, por exemplo. Mas muitas vezes chega cansada e também não consegue raciocinar. Já o pai critica essa atitude da esposa. Para ele, o problema de fazer o filho compreender os conteúdos é da escola e não dos pais, e é por isso que não estuda com os filhos. Confiou na escola e espera que ela, com os demais profissionais, como psicopedagogos e tutores ajudem a criança". Seja como for, Mônica não aguenta e acaba estudando junto com o filho. Entretanto, reconhece que é uma dificuldade dela. Até seu terapeuta já a alertou de que está confundindo o seu papel de mãe com o de professora. Antes Mônica acompanhava detalhadamente as tarefas que o filho tinha de fazer consultando a agenda dele. Hoje em dia, não. É o próprio filho quem fala quais são seus compromissos. "Às vezes era a tutora quem contava", lembra o pai. Por orientação da psicopedagoga, colocaram um mural de cortiça em que o filho coloca todos os compromissos lá. Sem dúvida foi difícil para a mãe parar de estudar com o filho mais novo, porque muitas vezes sente que o está abandonando. Se bem que ele se queixa de que ela pergunta excessivamente dos estudos. Com o filho mais velho, ela também estudava, mas ele não demandava tanto a sua ajuda, acabava sendo mais pontual. Ou seja, a sua disposição para estudar com os filhos é a mesma tanto para o mais velho quanto para o mais novo, mas é o mais novo quem mais solicita. 
Quando o aluno não está bem, o orientador da escola costuma chamar a família para conversar, sem o aluno estar presente. Além das informações do boletim, o orientador passa para a família outras observações de todos os professores: se o aluno está atento às aulas ou não, como está se comportando, etc. Depois dessa reunião na escola, eles passam essas observações para os filhos. Já foram chamados pela escola também por problemas de comportamento e por situações de briga entre amigos dos dois filhos. Mas foram situações pontuais.

Justo quando eu disse que a entrevista estava encerrada, o pai disse que tem observado não só na escola dos filhos, mas também em outras, um "excesso de estudo, muita matéria". Atribui isso ao ranking de escolas que a imprensa faz em função dos resultados do ENEM, o que é "o fim da picada", segundo a mãe. Talvez esse excesso de estudo explique a dificuldade maior de quem já tem dificuldade, como é o caso do seu filho mais novo. Inclusive vários profissionais com quem tiveram contato, segundo a mãe, criticam o excesso de conteúdos imposto pelas escolas. Não é só o filho mais novo que estuda muito, mas o mais velho também. Além disto, para a mãe os conteúdos são bastante complexos para a idade deles e não se sabe o que realmente eles apreendem de tudo que é dado.

\section{Quarta Entrevista}

$(10 / 04 / 08)$

Esta entrevista foi realizada com o casal Cristina e Rui, na residência deles. Têm quatro filhos, os três mais velhos estudando na mesma escola e o mais novo em outra. Antes de irem para a atual, fizeram parte da mesma Educação Infantil em que está o mais novo. "Por que escolheram a escola em que estão os três filhos mais velhos?", perguntei. Primeiro porque o pai é ex-aluno, mas na verdade disseram que não foi esse o principal motivo. Inclusive estavam bem satisfeitos com a escola anterior, que oferecia um bom ambiente para as crianças. Até achavam que a atual escola seria ideal para eles estudarem a partir da $5^{a}$ série ou mesmo só no Ensino Médio. Ocorre que essa opção "não existe,[...] na $5^{a}$ série é uma roleta russa e não se tem essa opção". Mesmo sendo longe de onde moram, queriam que os filhos 
estudassem lá. A mais velha foi na primeira série; os outros, no final da Educação Infantil, quando o processo de entrada não é tão concorrido.

Sem dúvida, "O principal critério foi o modelo de educação que a atual escola oferece". Não só é uma boa escola em termos de conteúdo, como também tem toda uma preocupação com valores, "com a postura das pessoas na sociedade". Além de "preconizar a independência com responsabilidade", diz a mãe. "Não partilham da ideia de que a disciplina se faz na escola, não vão delegar para a escola papel de disciplinar os filhos e não termos controle nenhum deles aqui”, continua o pai. É uma escola que permite que os alunos tomem decisões e depois arquem com as consequências, o que, segundo o pai, prepara melhor os filhos para vivenciarem outros ambientes menos disciplinadores, como a faculdade, por exemplo. Segundo eles, não é uma escola "policialesca", que vigia o aluno o tempo todo. Também, por meio da diversidade do seu corpo docente, oferece uma visão diferente da família. "O papel da escola não é reproduzir o modelo família, mas trazer outros modelos, outras visões, até para o aluno decidir qual ele quer seguir", disse o pai.

Se o processo de entrada não fosse tão concorrido, eles teriam preferido que os filhos fizessem o Ensino Fundamental I na antiga escola. "Por quê?", pergunto. A antiga escola "é muito divertida, você demora mais para achar estudar chato". Numa escola mais formal, como a que estão, rapidamente podem passar a não gostar de estudar. "O prazer de aprender eles tiveram na antiga escola", explica o pai. Segundo Cristina, Rui tinha mais certeza de que a atual escola seria boa. Mas se surpreenderam positivamente, porque ela avançou do tempo em que o pai estudou até hoje. Apesar da quantidade de alunos, consegue ver cada criança se desenvolver, e a organização do espaço, onde as crianças andam livremente, permite que eles tenham mais autonomia. "Quais foram os critérios para a escolha da antiga escola, que também não é próxima de onde moram?" Após visitarem várias, acharam que foi ela que apresentou a melhor estrutura para desenvolver a proposta de fazer com que a criança desenvolva seu próprio raciocínio e tenha prazer com isso.

A possibilidade de os alunos participarem de trabalhos sociais os pais também veem como positivo na atual escola. Tanto que a filha mais velha já se envolveu em algumas dessas atividades e foi muito interessante. Apesar de ser uma escola de 
origem católica, permite uma pluralidade de religiões lá dentro. O ensino religioso é mais pautado em valores, em princípios universais, do que no catolicismo, o que é apontado como outra qualidade da escola. Inclusive essa posição da escola é bastante "avançada", para o pai.

Quando moraram no Chile, relata Cristina, não quiseram que os filhos estudassem numa escola católica porque perceberam que eram "muito rígidos". Só para matricularem as crianças, por exemplo, precisavam mostrar a certidão de casamento religioso. Além disso, o ensino era pautado por regras e fórmulas, sem uma preocupação com o desenvolvimento do raciocínio. Inclusive Mariana, a filha mais velha, que se revelou uma excelente aluna no Chile, teve dificuldades para se adaptar ao método de ensino no Brasil. "Ensinar a pensar, ensinar a ter senso crítico, ensinar a ter opinião própria, especialmente quando a opinião do grupo é forte, como gerenciar a opinião do grupo com a sua", disse a mãe. "Não que a escola ensine isso, mas oferece algumas ferramentas junto com a própria família", continua o pai.

Os aspectos negativos são pontuais, segundo Cristina, como, por exemplo, uma orientadora na qual não sente muita confiança ou uma professora que não é tão boa. Justamente o segundo filho teve uma professora que "foi péssima, fez mal para ele". Em outra ocasião, uma professora desconfiou de que uma redação da filha mais velha não tinha sido feita por ela. Entretanto, relata a mãe, quando foram à escola conversar, o encaminhamento dado foi muito bom. "Na medida em que nossos filhos vivenciam esses problemas pontuais, eles se preparam para situações que vão ter de enfrentar na vida, pois, afinal, não existe uma escola perfeita", continua o pai.

A percepção de que a professora que não foi legal para o segundo filho, o Paulo, foi mais uma observação deles do que uma queixa do menino. Como é um garoto muito cheio de energia, a professora não soube aproveitar isso e ele passou o ano "abafado", com uma pequena queda no aproveitamento. Inclusive outras professoras souberam lidar melhor com essa característica dele, colocando-o para trabalhar mais. Não procuraram logo a escola porque imaginavam que a questão era em casa. Quando procuraram a orientadora, ela perguntou de início se Paulo gostava da professora, o que deixou claro para eles que a escola sabia do problema e não 
tinha tomado nenhuma providência. Segundo o pai, a reciclagem de professores é outro ponto negativo da escola, pois há professores muito antigos que "talvez não estejam atualizados". O fato é que não há muita agilidade em mandar embora professores ruins ou que não estão mais correspondendo às necessidades da escola. Os pais acham que talvez a escola pudesse ter um sistema de avaliação de professores mais eficiente e sistemático.

"Há algumas desvantagens de uma escola muito grande", continua Cristina, "às vezes, não conseguem perceber que uma criança não está indo muito bem". Ela disse que, então, cabe aos pais ficarem de olho para não deixar isso acontecer. "Para as crianças que estão num bom momento intelectual e emocional, é a escola certa", continua Rui, "mas se estão precisando de um pouco mais de ajuda, é preciso pensar". Como a terceira filha está num momento mais difícil, eles estão pensando, "se está na escola certa de acordo com o ritmo dela", sobretudo por ser, segundo eles, uma escola de ritmo forte, que não espera muito alguém que tenha alguma defasagem, "é um bonde que vai andando". Hoje a filha está com psicóloga, fonoaudióloga e também reforço na escola. Mas os pais entendem que todo esse apoio deva ser temporário, pois não querem que ela permaneça toda a vida escolar assim. Com certeza estão satisfeitos com a troca de informações entre a escola e os profissionais. O fato é que o processo avaliativo da escola é muito bom, tanto os relatórios quanto as provas.

Sempre um dos dois vai às reuniões de pais e, quando possível, vão os dois. Algumas são muito boas, outras cansativas. Para eles interessa "ver a cara dos professores". Justo na reunião da classe da filha mais velha este ano foi ruim, porque houve uma exposição longa e teórica sobre o estudo do meio que não permitiu que outros professores se apresentassem. Até outros projetos que desenvolvem e que poderiam ser mais bem explicados, como o de sexualidade e drogas, foram relatados de maneira superficial. Por certo essa parte poderia melhorar, "levando para o lado família-escola, mesmo". Na reunião da classe do segundo filho também houve uma explicação detalhada sobre o estudo do meio e sobre o ciclo do café, e a parte com a professora de sala, a que mais interessava a eles, foi mais rápida. Eles acham que poderia ter sido o inverso. Seja como for, não querem saber tão detalhadamente o conteúdo que estão ensinando às crianças, mas a rotina, o cotidiano da escola. 
Também sempre vão às mostras de trabalhos, que são muito bem-feitas. No Ensino Fundamental II há exposições. "É bonito, é de muita qualidade", afirmam. As exposições dos trabalhos dos menores acontecem nas salas, e os pais devem chegar mais cedo para vê-las. Sem dúvida, nessas apresentações as produções das crianças são muito valorizadas. Os pais participam também da festa dos esportes, principalmente quando as crianças estão no Ensino Fundamental I, assim como de eventos sociais como missas e festas juninas.

A escola marca bem as passagens dos ciclos. Por certo há uma diferença grande quando os alunos entram na $1^{\text {a }}$ série, "saem do cercadinho", quando a escola estimula os pais a não irem buscar as crianças na classe, mas a marcarem um ponto de encontro. Quando passam para a $5^{a}$ série, a multiplicidade de professores faz com que o jeito de estudar e de administrar a lição de casa também passe a ser outro. De fato a escola dá um suporte, mas os alunos têm de se adaptar, porque são ciclos bem diferenciados.

"Os filhos, principalmente a mais velha, demonstram desprazer pela escola ou por estudar?". Mariana é muito tranquila e autônoma em relação aos estudos e, portanto, não demonstra, nem verbaliza esse tipo de coisa. Agora, na $7^{\mathrm{a}}$ série, ela está muito segura, e a questão de gostar de estudar ou não se associa mais aos professores. Mesmo a carga de lição sendo grande, ela não reclama. Já o segundo filho reclama mais de fazer as tarefas. Para os pais, essa questão do prazer de estudar está mais relacionado à criança do que à idade, à escola ou à estrutura familiar. Entretanto, observam que apesar de os filhos gostarem da escola, não os veem entusiasmados com o que estão aprendendo.

\section{Quinta Entrevista}

$(29 / 08 / 08)$

Vera é administradora de empresas, divorciada e tem três filhos. Todos estudam na mesma escola. Os mais velhos, desde a primeira série do Ensino Fundamental e o 
mais novo, desde a pré-escola. Um já se formou, a do meio está na segunda série do Ensino Médio e faz intercâmbio, e o mais novo, Murilo, cursa a sétima série do Ensino Fundamental II. Antes dessa escola, todos estudaram numa outra, pequena, na qual todo mundo se conhecia. A mãe gostava muito da escola. Entretanto, quis transferi-los porque tinha uma visão bastante positiva da atual escola "[...] em termos de qualidade de ensino, em termos de ser uma escola grande, com uma estrutura formal e liberal ao mesmo tempo". Como seu filho mais velho era um pouco tímido, chegou a ser criticada pela antiga escola por tirá-lo de um ambiente pequeno e colocá-lo numa escola grande. E justamente ele se adaptou muito bem. Era um bom jogador de futebol, acabou se sobressaindo por isso e criando uma turma enorme de amigos que se reúnem até hoje. "Como as coisas, às vezes, não adianta ir pela teoria".

O fato de a escola ter muitos alunos era também um fator negativo para ela. Afinal, fez Ensino Médio numa escola muito grande e não foi uma boa experiência: "nunca ninguém soube quem eu era, o diretor não sabia o que acontecia com os professores, os professores não sabiam o que acontecia com os alunos!". Contudo, surpreendeu-se com a capacidade de a escola manter a individualidade dos alunos, apesar de ter cinco ou seis classes de cada turma. Sempre que precisou tratar de alguma questão sobre seus filhos, as orientadoras sabiam exatamente o que estava acontecendo, especialmente com o mais novo, Murilo, que é uma criança "fora da curva da distribuição normal". Foram muito hábeis em lidar com suas dificuldades. Até comentou que muitos pais, quando os filhos dão problema, ficam com raiva da escola. Mas ela não tem o que recriminar. Quando Murilo foi reprovado na $4^{a}$ série do Ensino Fundamental, ela chegou a propor que mudasse de escola, mas ele quis continuar lá porque, não só ele, mas todos os outros, adoram a escola. O mais velho nem quis fazer intercâmbio, pois não queria perder seis meses do colégio; e a filha, quando foi, lamentou muito ficar longe da escola e dos amigos.

Segundo Vera, desde a Educação Infantil Murilo começou a apresentar problemas de aprendizagem. Ela era chamada na antiga escola porque ele não acompanhava a produção, apesar de ter um bom desenvolvimento na linguagem e no raciocínio. " $A$ produção dele sempre foi uma porcaria! Uma desorganização enorme, os desenhos eram rabiscos, a letra horrível [...]". Depois de procurar diversos profissionais, colocou o filho numa análise, porque ele também tinha problemas de 
relacionamento: "é muito explosivo". Nesse tempo todo, a escola foi muito paciente e compreensiva, dispondo-se a conversar inúmeras vezes com ela e com o psicanalista. "Incrível como a escola consegue manter a disciplina, a ordem e a organização com individualidade!", ela acrescenta. Hoje seu filho está melhor, e este é o primeiro ano em que ela ainda não foi chamada por conta da falta de aproveitamento dele.

"O que mais vê de bom na escola?" Ela ressalta a qualidade de ensino, principalmente nas disciplinas de português, geografia, filosofia, "a parte humanística e cultural". Há um incentivo à leitura, os alunos leem coisas atuais e ao mesmo tempo passam a se interessar por determinados tipos de filmes e por ler jornais. Já houve ciclos de debates para as famílias e para os alunos sobre atualidades e cultura, com pessoas de reconhecida importância, que foi muito bom, mas ela acha que os temas deveriam ser mais aprofundados e ter debates mais vezes. Relata que a escola investe em dois grandes eventos: a festa junina e a festa dos esportes; contudo, sente falta de um mesmo investimento numa "virada cultural". Até existe essa prática, mas que, para ela, não recebe a mesma dedicação das duas outras atividades. Exatamente pela importância que a escola dá ao esporte, é que seu filho mais velho, muito tímido, conseguiu se sobressair. Se houvesse o mesmo investimento em atividades culturais, talvez seu filho mais novo, que não é tímido, mas tem problemas de relacionamento, pudesse encontrar maneiras de conquistar espaços no grupo.

Apesar de seus filhos não concordarem com ela, uma das suas críticas é em relação ao ensino religioso. Acha que a escola não tem uma "visão moderna", principalmente comparando com outras áreas em que observa que a escola se renova bastante. Já as outras críticas são por situações pontuais. Apesar de gostar dos diretores da escola, a mãe acha que, às vezes, publicamente a direção assume uma posição um pouco autoritária e arrogante, o que não condiz com a prática cotidiana, que é bastante democrática. Também acha que, às vezes, há uma ideia predominante de que nesta escola se forma a elite, os líderes da sociedade e que, na sua visão, é um pouco pretensiosa e perigosa. "Todo trabalho que a escola faz é maravilhoso, muito sério, comprometido com a educação, com a ética, com a política, mas não vamos chegar lá em cima e ficar arrogantes. Um pouco de humildade é bom!" 
Costuma ir a todas as reuniões de pais. Agora avalia que elas poderiam ser organizadas em grupos menores para que pudessem ter um ambiente mais pessoal em que os pais pudessem de fato se expressar. Ela acha que perdem um longo tempo explicando, por exemplo, o sistema de recuperação, que poderia ser entregue por escrito. Os diretores fazem um discurso inicial, mas pela forma e pela quantidade de gente, não há espaço para os pais se colocarem, o que torna as reuniões um pouco burocráticas. Já No Ensino Fundamental I, os pais se reúnem em grupos menores, com a professora de sala, o que considera mais interessante porque há espaço para troca.

Como trabalha muito e sempre trabalhou, ela não tem o hábito de acompanhar de perto o estudo dos filhos. Apenas pergunta das lições e do boletim. Entretanto, interessa-se pelo que estão estudando de uma maneira mais espontânea: gosta de ler algumas redações que os filhos lhe mostram e acompanha conversas entre eles sobre alguns livros e as interpretações dos professores. Mas o dia-a-dia é mais focado na cobrança, até porque ela não tem paciência para estudar junto e também acha que não é sua obrigação.

Apesar de ela estar mais presente no cotidiano escolar dos filhos, o pai também acompanha a escolaridade. Nos momentos mais graves ele comparece às reuniões individuais e também participa das festas e eventos que a escola organiza. A escolha da escola foi em comum acordo com ele, um pouco antes de se separarem. Numa síntese do que pensa sobre a escola, Vera disse que realmente admira a sua capacidade de, com uma estrutura tão grande, ter uma visão individualizada de cada aluno e apóia sua visão sobre drogas e educação sexual. Mas acha que poderia ser mais explorado, assim como concorda com os seus valores sobre a questão da internet e da privacidade, mas também acha que esses assuntos mereciam ser mais bem trabalhados no currículo. 


\title{
ENTREVISTAS SEGUNDA ESCOLA
}

\author{
Primeira Entrevista
}

$(23 / 05 / 08)$

A entrevista foi feita com o casal, Mirtes e Felipe, num café em um shopping da cidade. Com três filhos, duas garotas mais velhas e um garoto mais novo, ambos optaram por uma escola Waldorf no início da escolarização. Só depois que os filhos encerraram o Ensino Fundamental II é que as duas garotas foram para a escola atual. Já o garoto fez um percurso diferente: saiu da Waldorf neste ano, na $8^{a}$ série, por razões que serão explicadas depois. A mais velha está na $3^{a}$ série do Ensino Médio e a do meio, na $2^{\mathrm{a}}$ série.

"Por que escolheram uma escola antroposófica?" "Pela filosofia, pela pedagogia, pelo conceito", disse Mirtes. Por meio de uma amiga, ela conheceu a pedagogia Waldorf e convenceu o marido a colocar os filhos nesse tipo de escola. Inclusive havia uma perto da casa deles. Justamente o que aponta como muito interessante é a participação dos pais no processo de desenvolvimento das crianças. O fato de as crianças não serem avaliadas por notas e de valorizarem a parte artística também é visto como positivo por ela.

Já Felipe ressalta que o que pesou na decisão foi o método de alfabetização bastante gradual, em que "a questão do momento lúdico da criança é muito valorizado" e o aprendizado se dá de maneira "natural". Sempre se preocuparam com uma educação mais ampla, não competitiva, e se consideram muito felizes com o resultado. Seus filhos gostam de ir para a escola, gostam de estudar e tiveram facilidade para se adaptar às outras escolas.

Quando terminaram o Ensino Fundamental, as duas filhas prestaram exames em escolas técnicas federais, mas não entraram. Fizeram isso mais para testar o nível de conhecimento, e não porque queriam um ensino profissionalizante. Os pais receberam a indicação da atual escola de amigos e, na conversa com o diretor na época, gostaram muito da proposta dela. Embora a escolha tenha sido deles, a filha 
mais velha também gostou. Segundo o pai, o diretor "foi decisivo", pois soube apresentar os professores e se mostrou muito dedicado. Verificaram que a escola realmente acompanhava os alunos de perto: "o que ele prometeu, ele cumpriu". Além disso, a adaptação da filha mais velha foi muito boa e tranquila. Não tiveram dúvidas, portanto, para matricular a segunda filha.

"O que mais veem de bom na escola?" É o fato de não ser muito conservadora, "os alunos são tratados de uma maneira mais solta, mais livre". Inclusive elogiam a condução da direção num problema com o uso de drogas: "trataram com objetividade [...] não entraram na coisa de ficar forçando a dedar, mas forçar a responsabilidade [...] até que apareceu quem era. [...] é desgastante, é mais difícil para a escola, mas mais rico para os alunos e para a escola também". Além disso, acham que o público é bastante diversificado: "vem gente de tudo quanto é bairro, de várias formações diferentes", o que proporciona uma convivência com diversos tipos de pessoas.

Sobretudo a qualidade de alguns professores, capazes de estimular os alunos a estudarem, é ressaltada pelo pai e pela mãe como um forte ponto positivo da escola. Algumas pessoas dizem que ela não é "puxada, é fácil". Na verdade, consideram que não é bem assim, "é uma escola para quem quer estudar, mas para quem só quer bagunçar, dá também". Por certo suas filhas terão de passar por um reforço, um cursinho para entrar na faculdade, porque trabalham mais a formação geral, o que é muito valorizado por eles. Apenas no segundo semestre da terceira série fazem uma revisão de conteúdos com ênfase no vestibular. Mesmo assim, eles acreditam que as filhas não devem conseguir entrar em universidades públicas; só se prestarem cursos menos concorridos.

Mais um aspecto positivo levantado pelo pai era um esquema de representantes de sala, criado pelo antigo diretor, que permitia um diálogo muito fluido com os alunos. Inclusive os representantes tiveram um papel importante no encaminhamento da discussão do problema do uso de drogas. E quando os representantes traziam problemas e questões, o diretor discutia, pensava numa solução, apresentava, explicava verdadeiramente. Para Felipe "essa coisa da representação é muito importante e muito mal trabalhada no nosso país. O representante precisa entender [...] que ele representa o grupo e não se representa [...]. Os pais estão criando os 
filhos para serem príncipes e princesas, e não para serem cidadãos, para serem colaborativos que pensam e entendem essa coisa de grupo [...]".

Quanto aos aspectos negativos, os pais relatam que houve uma mudança de diretor e que esse fato tem gerado insegurança entre pais e alunos. Não exatamente porque o novo tem uma forma diferente de agir, mas porque talvez indique uma mudança na proposta e nos objetivos da escola. Além disso, tiraram os melhores professores da $3^{a}$ série para colocá-los na $1^{\mathrm{a}}$, e os alunos se queixaram muito e sentiram que a escola "ficou perdida nesse processo [...] só alegavam que era uma reação emocional dos alunos". No entanto, para os pais houve objetivamente uma queda na qualidade do ensino. Mirtes também sente que a escola se transformou numa empresa. "Entrava lá e adorava cumprimentar as pessoas [...]. Hoje você se depara com vidros e, se quiser ser atendido, tem que entrar numa fila [...]". E ressalta que, para quem lida com adolescentes, é fundamental o contato humano. Por ora estão observando, não sabem se o filho mais novo também vai estudar lá. Talvez tudo esteja se acertando, porque a última reunião de pais foi melhor.

O filho mais novo estudou na mesma escola Waldorf das irmãs, mas quis sair antes de terminar o Ensino Fundamental. Foi para uma escola tradicional perto de onde moram e também se adaptou bem. Ele queria estudar num lugar maior, com mais gente. Como na Waldorf se estuda o tempo todo na mesma classe e com a mesma professora, os pais acham que ele estava um pouco rotulado como "bagunceiro" e tinha vontade de romper com isso, mas não sentia muito espaço nem no grupo, nem com a própria professora. Por isso atenderam ao pedido dele de mudar. Não que seja bagunceiro exatamente, mas é brincalhão e mais dispersivo do que as irmãs.

"O que acham das reuniões de pais?". "É o que dá para fazer", disse Mirtes segundo ela, há uma parte objetiva em que se fala do calendário, da programação, e depois os pais podem procurar os professores para saber do aproveitamento dos filhos ou para qualquer outro tipo de esclarecimento. Entretanto, eles quase nunca conseguem falar com os professores porque sempre há uma fila grande e, como suas filhas são boas alunas, não veem necessidade de perder esse tempo. Mesmo na outra escola do filho, as reuniões têm a mesma estrutura. "É chato, achamos que não é o ideal, mas não sabemos como fazer de outra forma", é a opinião deles. 
Já na escola antroposófica as reuniões eram melhores, porque explicavam a relação dos conteúdos trabalhados com a fase de crescimento dos filhos. "Nessas reuniões tínhamos verdadeiras aulas", relata o pai, que faziam com que os pais entendessem melhor o momento de vida que seus filhos estavam atravessando. Apesar de as filhas estarem mais velhas, ele continua achando importante entender melhor a fase de vida que estão passando: escolha profissional, vestibular... "É uma responsabilidade muito grande que gera um conflito, e esse amparo para o pai talvez fosse bem interessante". Na verdade ele considera que nas reuniões "o pai acaba sendo educado também! [...] Se forem bem preparadas pela escola, elas funcionam como um processo de educação para os pais". Mesmo com problemas, ele as considera "essenciais [...] para o acompanhamento [...] é essencial esse contato". Só que quem vai às reuniões com frequência é a mãe, pois ele vai apenas quando há um problema mais sério.

Nunca tiveram a experiência de serem chamados na escola por problemas de aproveitamento ou disciplinar. Eles é que a procuraram neste ano porque a filha mais velha terminou o namoro e teve uma queda de aproveitamento. Também não costumam acompanhar de perto, agora no Ensino Médio, as lições, etc., até porque "é mais difícil acompanhar o conteúdo". O que fazem é conversar sobre a escola e o que estão aprendendo de uma maneira mais ampla. Mas os filhos entre si conversam e se ajudam nos conteúdos e nas tarefas escolares.

\section{Segunda Entrevista}

$(11 / 06 / 08)$

A entrevista foi com Rosa, microempresária, casada, com três filhos. Só o do meio, Rodrigo, estuda na escola procurada por mim na terceira série do Ensino Médio. A mais velha é universitária, e o mais novo está no último ano do Ensino Fundamental II. Ao explicar a escolha da atual escola do segundo filho, a mãe relata que cada um deles teve percursos escolares diferentes. 
A mais velha, Pâmela, sempre estudou numa escola particular tradicional do bairro onde mora, caracterizada como grande e bem conceituada. Já Rodrigo entrou nessa mesma escola e não se adaptou. Até a $3^{a}$ série do Ensino Fundamental II não conseguia se alfabetizar. Depois de buscar muita ajuda de profissionais especializados, como psicólogos, a mãe conheceu a pedagogia Waldorf e resolveu levar o filho para esse tipo de escola, na qual ele se integrou muito bem, superando, inclusive, seus problemas de aprendizagem. Segundo Rosa, ela quis levar a filha mais velha também, mas foi desaconselhada pela própria diretora em função da sua idade, pois ela ia para a $7^{a}$ série e só estudaria dois anos, pois a Waldorf termina no final do Ensino Fundamental. E o mais novo começou a escolarização na Waldorf e, no ano passado, pediu para mudar por questões pessoais. Neste ano ele está em outra escola particular do bairro, mas não a mesma em que a irmã estudou.

Rosa lamenta que a filha não tenha estudado na escola Waldorf e disse que se "arrepende amargamente" da escolha que fez. Na época em que Pâmela começou a estudar, ela realmente achava que aquela escola do bairro era a melhor, era "muito limpa e organizada" e tinha boa reputação. E a filha acabou se dando bem. Mas com as dificuldades de aprendizagem que o segundo filho apresentou, percebeu que ele vivenciava "uma pressão emocional desumana lá". Como ele tinha dificuldade para aprender, ela começou a achar que ele é que tinha problemas e procurou Kumon, psicopedagoga e psicóloga. Entretanto, percebeu que, na verdade, era a escola que não conseguia trabalhar bem com o seu filho e com o tipo de dificuldade que ele apresentava, tanto que todos os problemas foram superados na escola Waldorf, na qual ele não se sentia pressionado. Relata que esses problemas estavam relacionados com uma depressão que ela própria viveu quando o filho era bebê e que o deixou muito inseguro na primeira infância. Era "uma criança que não se arriscava em nada, tudo ele tinha medo". Quando ela própria entendeu e superou seus problemas, o filho também melhorou e passou a aprender normalmente. Não é um excelente aluno, mas nunca mais teve problemas de aprendizagem ou de aproveitamento.

A mãe caracteriza a escola em que a filha estudou como uma escola que "vomita conteúdos e que cria jargões e modelos a serem seguidos”, sem considerar as diferenças individuais: "Lá ou você entra no padrão ou você é discriminado". Todo esse processo que ela vivenciou com o segundo filho fez com que valorizasse uma 
escola mais humanizada, que não se preocupa em impor modelos e transmitir conteúdos, mas que faça com que o aluno saiba usar, aplicar o que aprende.

Recebeu indicação do atual colégio de Rodrigo na própria escola Waldorf. O fato é que visitou várias escolas junto com o filho antes de optar por esta. Se na apresentação identificava na fala do diretor ou do coordenador uma intenção de "vender os pacotinhos prontos", já descartava, não conseguia imaginar o filho lá dentro. A decisão pela atual escola foi em comum acordo com o filho. Nesta ela se sentiu bem recebida pelo diretor, percebeu que, apesar de ser uma escola de Ensino Médio, na qual os alunos são mais velhos, ele os acompanhava de perto, conhecendo todos muito bem, além de ser muito atencioso com os pais. Também gostou da estrutura da escola, que é a mesma da faculdade, embora esse não tenha sido o fator decisivo.

Sem dúvida Rosa vê como qualidades da escola a organização, os professores e o bom atendimento aos pais. Todas as vezes que a procurou, sentiu-se ouvida e "prontamente atendida". Inclusive ficou impressionada com o conhecimento que o diretor mostrou ter do seu filho numa conversa em que o procurou para saber se corria risco de ser reprovado. Também percebeu que é uma escola que não impõe um padrão de comportamento, um único modelo a todos e que discrimina quem é diferente; há espaço para diferentes grupos de jovens. Um exemplo disso, para ela, é a não exigência de uniforme. Além disso, ela elogia a estrutura do prédio, que considera muito boa, principalmente a biblioteca.

Entretanto, ela e o filho estão um pouco insatisfeitos com a escola neste ano. Um dos motivos é que justamente o diretor que a recebeu saiu e ela não reconheceu no atual a mesma postura atenciosa e próxima do outro. Quando conversou com ele, sentiu-se apenas ouvida, percebeu que ele não se posicionou nem se envolveu com as questões que levava. Ainda observou outra mudança não exatamente da direção, mas talvez dos mantenedores da escola, na preocupação com a aparência, "de mostrar que tem estrutura, que tem grana, que tem poder e que isso é qualidade". Ela justamente quis uma escola diferente disso porque para ela "a qualidade está na essência". Além disto, acha que a escola "perdeu o padrão, principalmente a classe do filho dela". Segundo Rosa, os bons professores saíram ou foram transferidos para o primeiro ano. A turma do seu filho, mais velha e mais exigente, está com 
professores mais novos e com menos experiência. Os alunos estão ressentidos com a perda dos professores e do diretor.

Além disso, ela também discordou de um encaminhamento dado a um problema numa prova de biologia. A professora combinou com os alunos que teriam prova num dia em que tinham aula dupla. Na primeira aula, tirariam as dúvidas, e na segunda fariam a prova. Contudo, nesse dia houve uma mudança de horário, a professora não pôde dar a primeira aula e manteve a prova mesmo assim. Então os alunos, sem a aula de dúvidas, recusaram-se a fazer a prova, e a coordenadora deu zero para todos. Para Rosa a reivindicação dos alunos era justa e se a escola ensina os alunos a pensarem e a reivindicarem seus direitos, não deve "meter o pé no peito deles com um zero". Foi justamente para falar sobre sua discordância com esse encaminhamento que foi falar com o novo diretor. Não acha que eles deveriam voltar atrás e tirar o zero, mas esperava que a escola reconhecesse que não foi a melhor maneira de resolver o conflito. Esperava que conseguissem com que os alunos entendessem que seus motivos eram justos, mas a forma como reagiram diante da situação foi inadequada. Enfim, considera que essa atitude autoritária da escola pode fazer com que os jovens desistam de lutar pelos seus direitos e assumam uma postura indiferente perante as injustiças que ainda vão encontrar.

É exatamente isso que vê de ruim na atual escola de Rodrigo: a classe dele perdeu os bons professores "que tinham uma coisa muito especial, criavam o interesse [...] e não davam moleza"; houve uma mudança na direção que para ela pode indicar novas diretrizes; e a inabilidade ao conduzir o problema da prova de biologia. $\mathrm{O}$ certo é que por essas razões ela está em dúvida se coloca o filho mais novo, que vai para o Ensino Médio no próximo ano, nesta escola. Gostaria que ele entrasse numa escola técnica do estado. Primeiro, porque é gratuita, e grande parte da renda familiar é dedicada à educação dos filhos e esse é um dinheiro que pode ser poupado. (Nesse momento ela relata que todo final de ano procura as escolas dos filhos para solicitar bolsas). Segundo, porque acha importante o ensino vinculado a alguma experiência profissional, mesmo que o aluno não venha a seguir aquela profissão futuramente. Contudo, acha que ele não terá condições de entrar porque é muito concorrido. Com certeza sairá em busca de escolas novamente. 
Rosa procura comparecer a todas as reuniões de pais, mas prefere os contatos individuais. Até nas reuniões ela sente uma mudança de conduta da escola. Nos primeiros anos "era como se fosse uma confraternização entre pais e escola". Eram recebidos com uma mesa de sanduíches e frutas muito bem arrumada pela turma de Hotelaria, e ela se sentia como se "estivesse chegando para um evento". Além das diretrizes gerais, convidavam palestrantes para falarem sobre adolescência, drogas, "sobre um tema do momento do teu filho, da vida do teu filho", e ela considerava isso muito produtivo. Neste ano, por exemplo, não foram recebidos da mesma maneira e só se tratou das diretrizes gerais, sem nenhum convidado. Houve também um espaço só para os pais da classe do filho para tratar de algumas questões levantadas por eles. Talvez a mudança tenha sido apenas para os pais da terceira série, mas ela não tem certeza.

Apesar de seu filho não ser "um aluno nota dez, é um aluno cinco, seis" e fala abertamente que não gosta de escola. Entretanto, ela nunca teve a experiência de ser chamada na escola por problemas de nota ou por mau comportamento dele. É ela quem costuma procurar a escola quando tem alguma preocupação. Seu marido, segundo Rosa, não acompanha a escolaridade dos filhos, "fica total comigo". Inclusive ele não participou da escolha das escolas. Só se interessa pelo boletim, pelos resultados. "Se foi mal, quer saber por que foi mal, se não estudou, se ficou folgado". O acompanhamento do dia-a-dia, de provas, trabalhos, etc. fica com ela. Procuram o pai, que é engenheiro, para tirar dúvidas concretas na área de exatas. De fato a escola se comunica muito bem com os pais via e-mail, enviando boletins do que está acontecendo. Se não fosse isso, talvez seu acompanhamento falhasse.

Depois de encerradas as minhas perguntas, Rosa enfatiza que "a coisa principal é que você tem que ficar focada neles (filhos), tem que ficar preocupada, você não pode só pagar uma boa escola e deixar seu filho lá dentro, achando que está tudo bem, que a escola é ótima, os professores são ótimos, o diretor é ótimo. Não. Acho que a coisa mais fundamental [...] é que você esteja acompanhando, você esteja sabendo como seu filho está se sentindo lá dentro [...]. É a parte mais importante do nosso desafio enquanto pais e mães [...]". 
Terceira Entrevista

$(20 / 06 / 08)$

A entrevista foi feita com o casal Arnaldo e Carla; ele é o pai e ela, a madrasta de Maísa, que cursa a $2^{a}$ série do Ensino Médio da escola pesquisada. Desde os oito anos, a garota mora com o pai e tem pouco contato com a mãe. A decisão de ela morar com ele se deu por diversos fatores: um deles é que na casa da mãe não tinha quem a acompanhasse e a ajudasse nas tarefas escolares, e isso estava prejudicando o seu aproveitamento. Além disso, a mãe, que era muito jovem quando ela nasceu, casou-se novamente e o marido não aceitava a filha dela, diferente da madrasta, que desde a época de namoro com o pai construiu um bom vínculo afetivo com ela.

Antes de estudar na atual escola, Maísa estudou numa escola particular de bairro cuja administração era feita por um padre, o que correspondia às crenças religiosas da família. No ano de 2006 mudaram-se dali e procuraram outra escola melhor e mais perto de onde foram morar. Entretanto, ela só cursou um ano naquele colégio porque seus pais (pai e madrasta) observaram uma mudança de comportamento e de valores nela. É que o público de lá tinha um poder aquisitivo um pouco mais alto do que o deles, que começaram a ter problemas com o universo de convivência da garota. "Era uma escola que fugia totalmente do nosso padrão social e econômico [...] a gente começou a ter problemas com isso [...] os típicos problemas de roupas, tênis, costumes". Até da família ela começou a se afastar em função da origem mais humilde de todos. Então decidiram tirar Maísa da escola, e ela voltou para a antiga, no bairro onde moravam antes.

Já a escolha pela atual escola foi da própria filha, pois ela tinha uma grande amiga cujos irmãos mais velhos e o próprio pai haviam estudado lá. Já era uma coisa decidida na família de que a garota iria para essa escola, e Maísa quis ir também. Para o pai era importante que ela fizesse um ensino técnico, porque foi o percurso que ele próprio fez e que o ajudou a se inserir no mercado de trabalho. A madrasta disse que foi mais resistente, porque queria que ela fizesse as próprias escolhas e não fosse influenciada pelas amizades. Mas o fato é que quando foram conhecer a 
escola, acabaram gostando da apresentação feita. Além disso, pesquisaram sobre ela, tiveram ótimas referências e, portanto, acabaram concordando com a opção da filha. Maísa faz o curso técnico em publicidade.

Uma das qualidades da escola é que mantém um contato muito grande com os pais, sempre os informando do que está acontecendo. Se os alunos se atrasam ou não levam material, telefonam ou enviam e-mail informando-os. São ágeis e eficientes na comunicação e têm uma preocupação e um cuidado com a segurança dos alunos. Além disso, os pais observam que o nível de ensino é bom e ela própria elogia alguns de seus professores, conta empolgada como são as aulas. $\mathrm{Na}$ visão da madrasta, são professores que trazem um pouco de idealismo, o que é importante para os jovens.

Nesta escola não encontraram o problema de valores da outra, porque ela tem um público bastante diversificado. Segundo a madrasta, os adolescentes "são muito autênticos [...] cada um tem seu modo de ser, seu modo de vestir e eles se encontram, são várias tribos [...]", o que também permite que a filha seja do jeito que é. Como treina handebol em clube, gosta de ir para a escola com a roupa de treino, sem muita vaidade. O fato de Maísa se dedicar ao esporte, treinando todas as tardes, os tranquiliza: "ocupa o tempo". Afinal, a madrasta trabalha o dia todo e o pai viaja muito e estuda. Nas palavras de Carla, "preocupa muito deixar o adolescente solto [...] se não fosse isso (handebol), eu não sei como é que a gente ia fazer".

Quando perguntei sobre os aspectos negativos da escola, disseram que não veem. Inclusive o pai lembra que teve dúvidas, no início, a respeito de como a escola lidava com a questão do cigarro e do namoro e se tranquilizou porque lá não é permitido fumar e nem namorar. Não que esse tipo de coisa não aconteça, mas "imagine em um ambiente em que isso for permitido! Aí ninguém vai estudar [...] escola é para estudar".

Os dois costumam participar sempre das reuniões de pais porque acham importante saber como a filha está na escola e também para se apresentarem para os professores. Para o pai as reuniões são fundamentais, mas a escola deveria promover mais ações que integrassem os pais. E Carla complementa, dizendo que "os pais hoje em dia acham que a escola tem a obrigação de educar os filhos [...]. Em contrapartida, o colégio permite que os pais tenham esse pensamento 
justamente por não promover tanto a integração com os pais." O fato é que consideram boas as reuniões em que todos os professores ficam disponíveis para atender os pais. Entretanto sentem falta de mais eventos envolvendo pais e alunos, tanto para interagirem mais como também porque percebem que a filha fica orgulhosa com a presença deles.

Por duas vezes a filha recebeu advertências por comportamento inadequado e nas duas vezes o pai apoiou a escola integralmente. Na primeira, receberam um bilhete da professora de química dizendo que Maísa havia tido um ato de "insubordinação". Imediatamente foram até a escola conversar e ficaram sabendo que a filha dormia na aula. Como a professora chamou a sua atenção, ela achou injusto e discutiu. Não só o pai deu razão à professora, como deixou bem claro que dentro da sala de aula é "o professor quem manda" e isso deve ser respeitado. "Afinal, não vivemos numa anarquia". Depois disso, não só a filha melhorou, como a professora é uma das que ela mais gosta.

A outra advertência foi porque a filha ia para a escola de sandália papete, o que era proibido. Já tinham chamado a sua atenção várias vezes, mas, mesmo assim, ela insistia. Até que um dia o pai disse que, se para ela era tão importante ir para a escola de papete, o melhor era mudar para uma escola em que esse tipo de calçado fosse permitido. E depois dessa conversa, a filha passou a ir de tênis, sem problemas. Não se lembram de alguma situação em que discordaram da postura da escola. Apenas relatam uma reunião em foi discutido o uso de uniforme. Eles eram favoráveis, mas a maioria dos pais não e, portanto, perderam. Por outro lado, consideraram razoável o argumento da segurança levantado pelo diretor, pois jovens com uniforme podem de fato chamar mais a atenção de assaltantes, etc.

É verdade que o forte da filha não é o estudo. Ela cumpre o que é preciso, mas não gosta de estudar; gosta mesmo é de esporte. Tanto que seus professores sempre dizem que é inteligente, mas que conversa demais em aula. Porém, em época de provas ela acaba estudando bastante, o que a leva a ter resultados razoáveis. Os pais não estudam com ela, mas ajudam quando solicitados. 
Quarta Entrevista

$(18 / 08 / 08)$

Maria é psicóloga, separada, mãe de Joana, sua única filha, que cursa a $3^{a}$ série do Ensino Médio na escola pesquisada por mim. Como Maria sempre trabalhou, inicialmente a filha frequentou o próprio centro de educação em que trabalhava, mas depois foi para uma escola pequena perto de sua casa que priorizava os cuidados físicos e a segurança no espaço. Quando a filha estava já na idade pré-escolar, Maria procurou uma escola "construtivista" localizada num sítio em que a filha podia ficar o dia todo. E ela permaneceu ali até completar o Ensino Fundamental II, fazendo parte de uma das primeiras turmas da escola. Durante esse período Joana manifestou vontade de mudar de escola, porque se incomodava com o fato de conhecer todo mundo. Queria fazer novas amizades! Então a mãe conversou muito com ela, dizendo-Ihe que teria muitas outras oportunidades para fazer amigos, e matriculou-a no handebol para ampliar suas relações sociais, mantendo-a lá até encerrar o ciclo porque julgava importante e confiava muito na proposta da escola. "Não era uma vontade dela; era mais um embalo, porque todo mundo ia sair", disse a mãe.

Apesar de gostar muito do ensino construtivista, Maria disse que em vários momentos ficou em crise, sem saber se aquele era o melhor modelo de escola. "Eu tive várias crises nesse processo de ser construtivista ou não, de estar dando uma formação legal ou não, mas o trabalho que foi feito de convivência, de valores, e essa relação com o estudo eu acho que foi muito bom pra formação dela". Hoje Maria considera a experiência muito positiva, não só porque permitiu que a filha tivesse uma relação menos tensa com o aprendizado (acrescenta que ela já é bastante perfeccionista), mas também porque a escola se preocupava com a formação dos pais, fazendo reuniões para explicar como se dava o processo de alfabetização, por exemplo.

Justamente no final do Ensino Fundamental, Maria ponderou que uma escola técnica poderia oferecer algo que pudesse complementar a formação de Joana. Matriculou-a num cursinho para se preparar para os exames das escolas técnicas 
federais, mas ela não passou. Segundo Maria, a filha tem dificuldade para controlar o tempo nas provas. E a escolha pela escola atual se deu porque ela oferecia ensino técnico e também pela apresentação, feita pelo antigo diretor, da proposta pedagógica. Pareceu-lhe que a escola era preocupada com a formação global do aluno e valorizava o esporte, o que era importante para sua filha. Além disso, apesar de cara para suas condições financeiras, Maria conseguiu um desconto, tornando a escola ainda mais acessível. E como ela fica no centro da cidade, Joana teria que ir de metrô, o que a mãe viu como uma oportunidade para a filha adquirir autonomia. $E$ mais: tinha o fato de não ser muito grande, porém maior do que a anterior, e de que outros alunos da antiga escola também iriam para lá.

"Quais as qualidades da escola?", perguntei. Além do que já tinha dito ao explicar as razões da escolha, Maria aponta o sistema de avaliação como uma qualidade, pois permite que o aluno refaça provas em que não tenha se saído muito bem e ainda inclui trabalhos, o que favorece que ele se torne mais responsável. $\mathrm{O}$ antigo diretor também foi citado porque era bastante atento aos alunos não só do ponto de vista do rendimento escolar, mas também dos hábitos e comportamentos, além de ter uma boa capacidade de dialogar tanto com os alunos como com os pais. E Maria ainda ressalta o trabalho de escolha profissional.

Entre os aspectos negativos, Maria disse que neste ano, com a saída do antigo diretor, a coordenação da escola está perdendo a capacidade de dialogar com os alunos. Houve um problema com uma professora e, na sua visão, a escola não manejou muito bem a situação. O fato é que Maria não é uma mãe que dá ouvidos a todas as reclamações da filha, o que é inclusive uma queixa dela, que diz que a mãe "dá sempre razão para o professor"! Só que nesse caso Maria acha que não deram espaço para os alunos se colocarem, e a situação se extremou. Então ela procurou a direção e a coordenação para discutir a questão. Sente que "ficou uma relação de poder diferente". Mesmo assim, não tirou a Joana porque é seu último ano na escola, mas se a filha estivesse nas séries iniciais talvez considerasse essa possibilidade.

Maria costuma ir a todas as reuniões de pais. Quando perguntei como as avalia, ela respondeu que não sabe direito qual seria o melhor modelo. Na antiga escola, gostava. Geralmente participavam, além da coordenação, um ou dois professores, 
que apresentavam o seu trabalho, o que permitia que os pais entendessem melhor o projeto desenvolvido, porque muitas vezes "você não consegue perceber isso na fala dos alunos". Na atual escola há uma fala mais geral e depois os pais devem procurar os professores para saberem do aproveitamento dos filhos e "aí não tem jeito: é fila"! Como sua filha não tem grandes problemas de nota, acabava conversando pouco com os professores. Já houve algumas reuniões em que foi um profissional para falar da adolescência e outra em que foi abordado o vestibular e a escolha profissional, o que Maria avaliou positivamente.

Nunca foi chamada na escola por causa de problemas com nota e comportamento. Só uma vez a filha foi suspensa por não respeitar uma regra de segurança, mas Maria deu razão à escola. Quanto perguntei sobre o pai, Maria disse que ela sempre tomou a frente nas decisões sobre a escola da filha. Muitas vezes eles discutiram porque, em situações financeiras desfavoráveis, ele considerava a possibilidade de a filha ir para uma escola pública, e Maria discordava. Sempre deu prioridade à educação, mesmo que para isso tivesse de abrir mão de bens materiais. Não tem carro, por exemplo. Logo que se separou, passou por sérios problemas financeiros, mas a antiga escola fez acordos que permitiram que ela continuasse. Hoje o pai acompanha o aproveitamento e vai a jogos ou apresentações na escola porque a própria Joana cobra. Mas no que se refere a limites e comportamentos da filha, ela e o pai costumam se entender. 


\title{
ENTREVISTAS TERCEIRA ESCOLA
}

\author{
Primeira Entrevista
}

$(06 / 09 / 08)$

Ivone, jornalista e divorciada, é mãe de Carolina, sua única filha, que cursa $07^{\circ}$ ano ( $6^{a}$ série) da escola pesquisada e estuda lá desde a primeira série $\left(2^{\circ}\right.$ ano) do Ensino Fundamental I. "Quais foram seus critérios de escolha?", perguntei. Em primeiro lugar, Ivone disse que, apesar de ter simpatia por outra escola, optou por esta porque era mais próxima da sua casa. Depois, relata que a filha fez uma Educação Infantil muito boa e vários pais desta escola decidiram pesquisar, em grupo, alternativas de continuidade para que as crianças permanecessem juntas. Ela considera importante que os outros pais da escola tenham um "jeito mais parecido" com o seu e que partilhem dos mesmos valores. Além disso, nessa época ela estava se separando e achou a atual escola bastante acolhedora. Então a decisão se deu pela junção de todos esses fatores. Desse grupo inicial de pais, vários se decepcionaram e tiraram os filhos, mas ela e seu ex-marido optaram por manter a filha lá. Afinal, Ivone acredita que não há grandes diferenças entre as escolas com a mesma proposta pedagógica da mesma região da cidade.

Quando começou a responder sobre as qualidades da escola, ela disse que voltou entusiasmada com a primeira reunião de pais do ano em que a escola comunicou que seria mais exigente. "Puxar mais [...] para realmente fazer com que os alunos estudem", ela falou, pois sentia que isso "era um pouco relaxado demais". E essa era uma das críticas que fazia à escola e o motivo de alguns pais terem tirado seus filhos. Em seguida, levantou outras: uma dificuldade em dar limites - relatou que uma vez foi levar a filha até a sala e se deparou com os alunos jogando mochilas pela escada, sem que a escola chamasse a atenção deles -, o curso de artes, que tem uma única professora do $1^{\circ}$ ao $9^{\circ}$ ano e que é uma pessoa "pouco estimulante e estimulável". Para Ivone, artes é tão importante quanto qualquer outra matéria e em diversas ocasiões já deu a sua opinião sobre o curso para a escola. 
De repente ela se interrompeu e perguntou o que exatamente tinha sido perguntado. Quando eu esclareci dizendo que era para levantar aspectos positivos, ela riu pela troca e retomou dizendo que em geral a escola é atenta aos alunos, promove uma boa interação entre eles, faz um bom trabalho de estímulo à leitura, "as crianças leem muito, leem muito", assim como nos trabalhos de campo "em que realmente eles (alunos) estudam de verdade." E reforçou que o fato de se mostrar mais preocupada em criar um hábito e uma disciplina de estudo nos alunos é positivo e a escola está corrigindo algo que era um pouco falho. Em relação à disciplina, Ivone considera que era um problema maior na antiga escola de Ensino Fundamental I, outra instituição que acabou se unificando com a escola atual.

Além das críticas que já tinha feito, Ivone observa que é difícil ter um acesso direto aos professores, principalmente agora no Ensino Fundamental II. Às vezes ela também sente que há pouco intercâmbio efetivo da escola com os pais. Apesar de terem um discurso de que fazem parte de uma comunidade e de que a integração família-escola é importante, "no final das contas a escola só se coloca para refletir sobre as críticas quando percebe que há uma evasão de alunos [...] porque de outro modo se colocam numa postura muito defensiva". Para ela há uma discrepância entre o discurso democrático e a prática tanto com os pais quanto com os alunos, 0 que gera uma sensação de que o que se fala é diferente do que se faz. E acrescentou mais um incômodo, que é uma impressão de que os professores veem pouco o material dos alunos, de que não há um acompanhamento tão próximo de como cada um está aprendendo.

Sempre que fez críticas à escola, isso ocorreu nas reuniões coletivas; nunca sentiu necessidade de marcar conversas individuais sobre isso. Mas o que a desagrada não é o fato de a escola não mudar a professora de artes, por exemplo, mas de não se sentir ouvida: "o que incomoda é esta impermeabilidade". Também se queixou da comunicação da escola, pois disse que as cartas são mal redigidas e só têm uma via. Então ela sempre tem de telefonar para esclarecer algum tópico e não tem respostas para os e-mails que envia.

Ivone gosta de ir às reuniões de pais, considera-as um momento importante para ouvir a escola e verificar o que ela está propondo, por mais que haja distância com o que de fato acontece. E costuma ir a todas. Apesar de alguns professores 
participarem das reuniões, ela sente falta de um espaço em que possa ter um contato direto com eles, sem a mediação da direção ou da coordenação. "Acho que ninguém ganha com isso, acho que tem que ter um fluxo entre a pessoa que está direto com seu filho e você [...] Pessoa a pessoa se resolvem muitos conflitos!". Ocorre que no ano anterior a escola propôs uma atividade para os pais conhecerem os professores, mas neste ano ela foi cortada, o que gerou protestos, e não só dela. Cada professor ficava numa sala e os pais iam até lá para conversar. "Pra mim foi incrível porque de cara eu entrei com uma professora que eu achei sensacional! Depois fui saber pela Carolina que todo mundo adora ela! [...] então é bacana você conhecer e ver como é aquela pessoa, como ela trabalha, o que fala [...]". Excetuando isto, Ivone avalia positivamente as reuniões. Sempre que tem dúvidas e discordâncias, ela as expõem.

Além das reuniões, a escola organiza vários outros eventos, tanto com convidados quanto com os próprios alunos, mas Ivone não consegue ir a todos. Muitas vezes, agora que a filha está maior, apenas a leva e depois vai buscá-la. É evidente que acha muito importante a escola oferecer esses espaços que incentivam o interesse social e cultural dos alunos. Num deles ela foi um pouco desconfiada porque era um evento que chamavam de "Declamação" e se surpreendeu muito porque eram dramatizações e a peça da sua filha acabou sendo premiada! À medida que Carolina solicita, Ivone procura ajudá-la nos trabalhos e lições, tirando dúvidas, apresentando materiais de consulta, etc., mas mais na área de humanas. Nunca foi de se sentar com ela para fazer as lições, até porque a filha sempre foi muito "autônoma".

\section{Segunda Entrevista}

$(16 / 09 / 08)$

A entrevista foi realizada com o casal Susana e Maurício, engenheiro. Eles têm três filhos: o mais velho engenheiro como o pai, o do meio, Dênis, cursa a $3^{a}$ série do Ensino Médio da escola pesquisada e o mais novo estuda na $1^{\text {a }}$ série do Ensino Médio de outra escola particular, a mesma que Dênis estudava antes. Explicam que o filho do meio sempre teve muita dificuldade de aprendizagem, principalmente nas 
matérias de humanas. Tem inclusive um diagnóstico de déficit de atenção com hiperatividade. Ocorre que ele se transferiu para a escola atual depois de ter sido reprovado na $2^{a}$ série do Ensino Médio. Segundo a mãe, ela achou que a antiga escola estava marginalizando-o, sem muita disposição para fazê-lo mudar de postura diante dos estudos.

Mesmo antes de Dênis ir para o Ensino Médio, eles eram chamados à escola com frequência por causa de seus resultados ruins. Mas a orientação da antiga escola relatava que o filho era preguiçoso e nunca sugeriu que investigassem melhor a origem das suas dificuldades. Até por isso eles se decepcionaram com a escola. Além disso, nessas reuniões sentiam que o problema era colocado de uma maneira unilateral. A descoberta do déficit de atenção se deu porque eles próprios decidiram investigar. Primeiro procuraram uma psicanalista, que também achou que ele poderia ter algum problema, até que chegaram a um neurologista, que confirmou o diagnóstico.

Hoje Dênis toma medicamentos e faz tratamento com uma fonoaudióloga que trabalha memória e o ajuda a estudar. Apesar desse problema, os pais achavam que o filho não devia estudar numa escola especial. A escolha pela atual se deu por indicações de professores particulares do filho, por ela ter a mesma linha pedagógica da anterior, ser um pouco menor e perto de onde moram. Embora Dênis tenha se adaptado do ponto de vista social ("uma semana depois já estava no time de futebol"), as dificuldades persistem. Entretanto, nas conversas com orientadores, sentem que eles buscam fazer parcerias e não jogar o problema para eles, pais, resolverem.

Quando escolheram a primeira escola de Dênis, relatam que buscavam uma escola em que as crianças tivessem liberdade, que não fosse muito disciplinadora e que valorizasse "música, artes, esportes, outras coisas que não só o português e a matemática". Até porque o primeiro filho, nove anos mais velho que Dênis, estudou numa escola tradicional de freiras perto da casa deles e não teve uma boa experiência, pois os valores não eram os mesmos: "Ele não gostava, ia forçado!". Receberam indicação de duas escolas com esse perfil e acabaram optando pela que julgaram menos "elitizada e estratificada". E dois anos depois, o filho caçula também 
foi para lá e continua até hoje, porque ele fez questão, tem boas notas e uma boa inserção social. Se fosse pelos pais, teria saído também.

$\mathrm{Na}$ verdade este filho teve uma doença grave ainda bebê que o deixou com uma deficiência física - usa cadeira de rodas. Nem pensaram na atual escola de Dênis como possibilidade, porque lá o espaço físico não é adequado: tem escadas, por exemplo. Inclusive relatam que mesmo a escola em que ele está não era adaptada para cadeirante. Havia espaço para elevador, mas não colocavam, obrigando o motorista deles a ficar lá toda a manhã para ajudar o garoto a se locomover. Depois de uma reunião em que a escola fez um discurso sobre igualdade, ficaram indignados e escreveram para ela apontando que o discurso não era coerente com a prática. Afinal, não se preocupavam em criar condições igualitárias para o seu filho. Imediatamente os pais foram chamados pela escola, que se desculpou e pediu a ajuda do pai para a instalação do elevador. E, só a partir daí, tiveram uma preocupação maior com isso. Portanto, muito em função das características especiais desse filho é que os pais não insistiram na mudança de escola.

Em diversos momentos, ao levantar as qualidades da atual escola de Dênis (a pesquisada), eles acabavam comparando-a com a anterior. O primeiro aspecto positivo que levantam é a qualidade dos coordenadores. Enquanto na antiga escola a coordenadora não tinha contato direto com os alunos, era "fraca no diagnóstico" e "meio que transferia o problema", na atual, como os coordenadores entram em sala, conseguem conhecer melhor seu filho. Fazem uma análise mais ampla, buscam fazer parcerias com os pais, "ajuda lá que eu ajudo aqui", e, quando conversam, recebem feedbacks não só dos resultados, mas também do comportamento dos alunos. Assim, sentem-se motivados e não vão embora achando que "o filho não tem jeito" como acontecia na antiga escola.

Outros pontos positivos levantados foram: o estímulo à curiosidade - percebem que os filhos se interessam pelo que acontece no mundo, pois querem discutir e saber a posição deles; o trabalho com literatura e a interação entre os alunos. E nesses pontos consideram as duas escolas semelhantes. Já na parte esportiva eles também acham que o trabalho na atual é melhor. Dênis sempre foi fanático por futebol, é bastante competitivo. Na antiga escola, por ter agredido verbalmente um colega, foi expulso do time, o que, para eles, foi uma punição exagerada. Têm certeza de que 
na atual o filho deve fazer coisas semelhantes, mas recebe punições mais compatíveis e não fica impedido de jogar, o que para ele é muito importante até pelo diagnóstico de hiperatividade.

Entre os aspectos negativos, levantam a preparação para o vestibular e para o ENEM. Não que seja ruim e sabem que Dênis não pode ser tomado como parâmetro, mas sentem falta da divulgação de dados mais objetivos da escola como, por exemplo, como trabalham essas questões com os alunos. Também apontam que, como o filho não traz muitas informações sobre o cotidiano escolar, sentem falta de uma comunicação mais direta com a escola para que eles possam incentivar o filho a participar das atividades propostas. A mãe cita, por exemplo, o trabalho de orientação profissional em que os alunos visitam o local de trabalho de profissionais e também a inscrição no ENEM e na FUVEST, atividades que o filho ficou de fora. "Com dezessete, dezoito anos já poderia ser responsável, mas não é. Então poderiam mandar por e-mail esse tipo de informação, para chegar até mim”.

Quanto às reuniões de pais, pai e mãe discordam inicialmente. Enquanto a mãe disse que acha importante e que apenas uma durante o ano é pouco, o pai não gosta e prefere as reuniões individuais: "Porque tem muita gente que só quer saber do seu filho! Ou acontece de "duas ou três pessoas que monopolizam [...] Ficam meia hora falando de um assunto que só interessa a elas"! Cita o exemplo de uma em que se passou mais da metade do tempo discutindo se a cantina da escola deveria ou não vender chocolates. Não que coisas como essas sejam problemas da escola, mas, na avaliação do pai, a escola poderia se colocar mais e atuar como mediadora. Sem se posicionar, acaba fomentando esse tipo de situação. Já a mãe disse que gostava da apresentação que os professores faziam do seu trabalho: "era interessante [...] e a gente acompanhava melhor". Mas também dá razão à crítica do marido. Consideram as reuniões de pais nas duas escolas parecidas, mas, no relato, acabam se referindo mais às reuniões da antiga escola.

Sempre são chamados pela orientação por causa das dificuldades de Dênis, mas na escola atual não discordaram de nenhum encaminhamento dado. Até mesmo o filho concorda com os coordenadores e com a diretora. Os pais sentem que Dênis os respeita, porque na outra escola ele simplesmente dizia que "pegavam no pé". Voltam a elogiar os atuais coordenadores e a criticar os da antiga escola. Em 
relação ao acompanhamento de lição de casa e trabalhos, dizem que cobram, mas não têm o hábito de estudar junto, inclusive porque os filhos não aceitam. Durante a escolaridade de Dênis, a mãe foi aos poucos deixando que ele próprio tomasse a iniciativa de procurar os professores particulares. Também acrescenta que agora é o pai que está mais à frente desse acompanhamento: é ele quem confere o boletim e corta atividades, como esporte e computador, quando os resultados não estão bons, etc. Durante muito tempo ela fez isso sozinha. Na verdade o filho corre o risco de não ser aprovado na $3^{a}$ série. Mas, se for aprovado, querem que ele passe um tempo no exterior como uma forma de amadurecer, antes de escolher uma profissão e prestar vestibular. $\mathrm{O}$ mais velho teve esta experiência e os pais avaliaram como positiva.

\section{Terceira Entrevista}

$(17 / 09 / 08)$

Bruna, professora universitária, é separada, mãe de dois filhos que estudam na escola pesquisada desde o $2^{\circ}$ ano ( $1^{\text {a }}$ série $)$ do Ensino Fundamental I. O mais velho está agora na $2^{a}$ série do Ensino Médio, e o mais novo no $8^{\circ}$ ano do Ensino Fundamental. "Quais foram seus critérios para a escolha da escola?”, perguntei. Em primeiro lugar, segundo a mãe, a localização - queria que a escola fosse perto de sua casa não só para facilitar o transporte, mas também para que os amigos dos filhos morassem perto; depois, por oferecer o período da manhã para os dois filhos ao mesmo tempo e, principalmente, porque uma amiga, que tinha os filhos lá, deuIhe boas referências. Depois essa amiga acabou se decepcionando, achou que a escola não trabalhava bem a questão do vestibular e tirou os filhos. Contudo, ela continuou, foi "a cliente fiel".

Entre os pontos positivos que a fez optar por esta escola, Bruna destacou que era acolhedora, trabalhava bem os conteúdos, tinha bons professores e um bom estímulo à leitura. Além disso, era importante para ela que seus filhos não fossem "mais um entre muitos". Por isso, visitou outras escolas com propostas semelhantes, mas esta foi a que, para ela, conciliou mais aspectos favoráveis. Apesar de 
esclarecer que, quando escolheu a escola, escolheu outra instituição que tinha, inclusive, outro nome e que acabou se associando com a atual. Isso aconteceu na época em que os filhos ainda estavam no Ensino Fundamental I. "Eu optei por uma e depois tive que engolir a outra." Na sua visão, a antiga escola tinha uma proposta mais "endógena", era menos preocupada com o mercado e com o marketing. Mas, com a fusão, incorporou atividades que não faziam parte das suas propostas. Cita um acampamento de lazer como exemplo que passou a fazer parte do currículo e que era muito caro, gerando protestos não só dela, mas de outros pais também. Além disso, ela, que tinha optado por uma escola pequena, deparou-se com uma escola grande. Agora que os filhos estão maiores, considera positivo a escola ser mais "encorpada", mas, na época, foi um desconforto.

"O que vê de bom na escola?", foi a próxima pergunta que fiz. Bruna enfatizou o trabalho de conclusão de curso que os alunos da $2^{\mathrm{a}}$ série do Ensino Médio realizam. É um trabalho que ensina metodologia de pesquisa e que ela, por exemplo, teve de aprender "na raça, sem a menor noção de como começa." O filho, ao contrário, está tendo a oportunidade de aprender algo que será fundamental na continuidade dos seus estudos: "É uma das grandes diferenças no Ensino Médio, uma das coisas que pesou para os meninos ficarem lá o tempo todo". Também aponta a qualidade dos professores - têm uma boa formação e um bom jeito de conduzir a conversa com os alunos -, a proximidade de casa (embora agora seus filhos vão e voltam sozinhos) e o fato de a escola ser crítica, "ensina um pouco a meninada a ser cidadão do mundo".

Ainda se lembra do trabalho de teatro que é "um diferencial enorme!", além das disciplinas optativas oferecidas, como astronomia, psicologia, entre outras. E considera importante também o ambiente da escola, pois "as famílias que têm seus filhos lá estão mais ou menos próximas da minha condição de vida, tanto do poder aquisitivo, quanto de valores". Mais para o final da entrevista ela também elogiou a qualidade dos orientadores: "Eles são de uma geração intermediária, entre os pais e os alunos, e acho que têm um approach muito legal com os meninos [...]". E ela acha que o fato de eles terem um horário programado para trabalharem com os alunos é muito bom porque "é a chance de os meninos conhecerem a coordenação e a coordenação conhecer melhor os meninos, de se ouvirem [...]". 
Já em relação ao Ensino Fundamental Bruna teve um pouco mais de críticas, porque trabalhos de pesquisas e matérias optativas não estão tão presentes no currículo e também porque houve muita troca de professores, tornando o corpo docente um pouco instável. Ela lamentou especialmente a saída de um coordenador, que para ela "era o ícone da escola". Mas como crítica à instituição como um todo ela apontou a fusão das escolas, que causou certa perda de identidade, mas agora ela está se recuperando; critica também a falta de professores: "tem-se a impressão de que os professores têm facilidade para faltar"; e critica os estudos do meio, que, para ela, "o ganho cognitivo em relação ao custo que isso provoca no orçamento da família é muito baixo!". Bruna também disse que é muito difícil ter acesso direto aos professores. Quando ela tem alguma questão específica para tratar com um professor, o máximo que consegue é conversar com a coordenação. Não há a possibilidade de marcar, via coordenação, uma conversa direta com o professor, "é mediado demais", o que a incomoda.

Contudo, em vários momentos da conversa Bruna expressou uma suspeita de que paga muito pelo que de fato a escola oferece: "[...] eu sempre acho que pago um preço muito alto pra escola, uma mensalidade muito alta, e a escola diz que é muito pouco! O esforço que eu tenho [...] o benefício não é proporcional!". Enfim, ela gostaria que a escola pagasse tão bem os professores que eles não quisessem sair e que os estudos do meio fossem em menor quantidade e mais coerentes com a proposta. Outro aspecto que a deixa insegura é a preparação para o vestibular. Até se lembrou de que quando os filhos eram pequenos ela tinha a convicção de que uma escola que se preocupasse com a formação global era a mais indicada. Mas agora que o filho mais velho se aproxima da hora de prestar o vestibular, ela pensa um pouco diferente. Todavia, essa é uma insegurança dela.

Bruna costuma ir às reuniões de pais. Com certeza a escola se esforça para cumprir tudo a que se propõe. Enviam antes por e-mail a pauta, os conteúdos curriculares dos cursos para que os pais leiam com antecedência e façam perguntas mais focadas. Mesmo assim, em algumas delas, alguns pais trazem casos particulares para a discussão, a coordenação "não segura muito a onda e as reuniões acabam sendo infrutíferas". Mas ela tanto gosta que acha que são poucas: uma ou duas por ano. Além disso, a escola promove muitos eventos pedagógicos e festivos e 
convidam palestrantes para falar com pais e alunos. Bruna vai aos pedagógicos; aos festivos, não.

Sempre que tem alguma questão, ela convoca reunião com os coordenadores. Uma vez foi questionar porque exigiam leitura obrigatória nas férias e sugeriu que os alunos recebessem no início do ano todos os livros que deveriam ler e se organizassem como achassem melhor. Porque para o filho "é um porre ficar lendo nas férias!" e para ela é uma imposição que pode justamente desmotivar a leitura. Sua sugestão não foi encaminhada, e a própria coordenadora nem sabia que os alunos deveriam ler dois livros. Inclusive tem assuntos que ela até já desistiu de discutir, como os estudos do meio, por exemplo, porque sente que a escola tem um discurso pronto. Nessas reuniões individuais ela é bem recebida, "mas as ideias param numa parede!". Uma única vez foi atendida: na reunião de apresentação dos professores que orientavam o trabalho de conclusão de curso. Como não estavam todos, ela questionou e fizeram outra reunião com os outros professores. Também reconhece que, nas situações de conflito entre aluno-professor, a escola tem uma boa acolhida.

Quanto ao estudo dos filhos, diz que os dois são muito independentes. Ela nem toma conhecimento do dia-a-dia deles, mas sabe o que estudam pelos livros didáticos que compra, dá uma olhada e também gosta de ler as provas, tanto para ver como os professores as elaboram quanto para ver como os filhos respondem. Eles "são excelentes alunos. Os dois estão entre os três ou cinco melhores alunos". Bruna e o ex-marido vivem "às turras" e, portanto, ela considerou que o que ia falar dele não é muito imparcial. Ele tiraria os filhos da escola por causa do preço. Já ela, apesar das críticas, é contrária porque considera que as escolas do mesmo nível custam mais ou menos a mesma coisa e a que o pai sugere é "mais fraca em todos os sentidos: pedagógicos, sociais [...]". Entretanto, ele vai às reuniões, marca para falar com os orientadores e acompanha o boletim. Ao final da entrevista, Bruna comentou que acha que passou uma imagem negativa e que gostaria de destacar que, apesar das críticas, ela gosta da escola e é sua opção que os filhos continuem lá, até porque "não existe a perfeição!". 
Quarta Entrevista

$(19 / 09 / 08)$

Karina e Márcio têm dois filhos: Cláudia, a mais velha e Daniel, o mais novo. Cláudia estudou desde a $1^{\text {a }}$ série (atual $2^{\circ}$ ano) do Ensino Fundamental na escola pesquisada e já se formou; Daniel, desde a Educação Infantil e agora está na $1^{a}$ série (antigo $1^{\circ}$ ano) do Ensino Médio. Ainda bebês, eles frequentaram a creche do trabalho da mãe. Em seguida, Cláudia foi para uma escola de Educação Infantil em que o pai conhecia a dona e, ao final desse ciclo, eles receberam a indicação da atual. Já Daniel foi direto para esta. Entre os critérios de escolha, citam a continuidade do "espírito" da escola anterior, o número reduzido de alunos, o projeto pedagógico, mas principalmente a afetividade e o acolhimento: "Não era uma coisa muito técnica [...], a sensação que eu tinha era de um jeito honesto de ser, [...] ter uma coisa menos comercial[...]", falou o pai.

Além disso, a escola tinha e ainda tem o cuidado de explicar e fundamentar as suas propostas, o que agrada bastante a ambos. Também apontam que ela estar no bairro em que moram foi um fator importante não só para facilitar a operacionalização de levar e buscar os filhos, mas porque os amigos moram perto, o que cria um ambiente mais comunitário. E, por último, disseram que as relações comerciais com a escola sempre foram tranquilas. Quando esta escola se juntou com outra, formando uma única instituição, eles tiveram um "pouco de resistência". Num tom de brincadeira, o pai disse que "não foram consultados! A gente é um pouco rebelde!". Entretanto, reconhecem que houve benefícios. Seus filhos já estavam maiores e a fusão das escolas deu uma "amplificada nas relações". Apesar das mudanças, reconhecem que a escola "se afina com o que a gente pensa".

Para Karina, até mais ou menos o meio do Ensino Fundamental, o projeto pedagógico e a execução são bem coerentes, mas a partir daí ela considera que a escola nem sempre consegue pôr em prática aquilo a que se propõe. Uma vez que não focam o vestibular, mas procuram fazer com que os alunos busquem informações e as analisem criticamente, a filha mais velha "pastou um pouco no cursinho, [...] é o preço que se paga [...]". Mas agora entrou no curso que queria, 
embora tenha amigas que querem medicina e ainda estão sofrendo. O pai acredita que, inclusive pela formação do colégio, a filha na universidade vai "deslanchar". Enfim, manter os dois filhos nesta escola foi uma escolha. Sua filha nunca quis sair, pois construiu um grupo sólido de amigos, e o filho em alguns momentos chegou a pensar nisso. No entanto, ela não concordou porque ele queria ir para uma outra escola muito parecida. Então o levou para conhecer uma escola técnica, e ele reconheceu que não queria mesmo sair.

"O que veem de bom na escola?", foi a próxima pergunta. Karina diz que os livros didáticos são bem selecionados (até tem dificuldade de se desfazer deles) e há uma complementação com fichas elaboradas pelos próprios professores. Também ressaltam a qualidade dos professores - são envolvidos com a proposta pedagógica, "fazem a diferença"! A área de artes é muito forte, com várias atividades, como exposições e eventos, assim como a área de esporte, que trabalha muito bem a questão da participação e da cooperação em equipe e, por isso mesmo, o time da escola nem sempre ganha os campeonatos. $E$ ainda ressaltam que a escola tem um bom espaço físico. Um pouco mais adiante da conversa, quando já se falava das críticas, a mãe se lembrou da proposta da tese que os alunos da $2^{a}$ série do Ensino Médio realizam. É uma proposta muito interessante, na visão deles, porque os alunos não recebem a informação, mas "eles vão atrás, [...] é um movimento mais novo [...]".

Já em relação aos aspectos negativos, Márcio disse que, às vezes, tem a impressão de que existe uma contradição entre o projeto pedagógico e a questão administrativa. E quando os alunos, que justamente aprenderam a serem críticos e a argumentar nesta escola, questionam essas medidas "desagradáveis", a escola não só não explica como não abre mão. Como exemplos dessas contradições citam o fato de professores queridos e significativos terem sido mandados embora e a mudança dos estudos do meio do Ensino Médio - antes viajavam para o Rio de Janeiro e atualmente a escola mudou para vários estudos em São Paulo mesmo, alegando que não precisavam ir tão longe para estudarem problemas metropolitanos. Claro que os alunos não gostaram! Mas também porque esse estudo do meio não foi bem executado. 
Karina concorda com o marido e reforça que sente essa contradição também no contato com os pais, com a comunidade: "Acho que a escola vive um conflito entre assumir essa coisa de um envolvimento muito maior [...] que a comunidade possa interferir mais e se afastar, em ser mais empresarial e não perder os alunos". O fato é que ela sente falta de participar mais do dia-a-dia da escola, tanto que fez parte da comissão de pais que ajuda a organizar a formatura do $9^{\circ}$ ano de ambos os filhos, 0 que foi uma experiência muito importante. Para ela, duas reuniões por ano é pouco. Inclusive, pensa que a escola deveria ter uma associação de pais e mestres, mas pondera que essa pode ser uma necessidade mais dela do que da maioria dos pais porque, em alguns eventos que a escola já organizou para a participação da comunidade, a adesão não foi tão significativa.

Uma vez, relata Karina, a escola contratou uma assessoria para trabalhar o comportamento de risco nos alunos. O trabalho não se restringia à questão das drogas, mas também internet, alimentação, comportamento sexual, etc. No início convocaram os pais para explicar o trabalho que envolvia, inicialmente, uma pesquisa. Depois chamaram os pais para apresentar os resultados, mas, à medida que as reuniões foram sendo mais pontuais, a participação foi diminuindo. Com isso, ela percebeu que "são temas delicados, porque alguns pais têm visões diferentes [...] pra escola é difícil entrar nesse contexto". E, apesar dessa tentativa, esse continua sendo um grande desafio para a escola. Quando tiveram de enfrentar essas questões com o filho, eles a procuraram para saber como lidar com isso, mas "a interlocução é limitada [...] não tem alguma coisa muito nítida a esse respeito".

Durante o processo de fusão entre as duas instituições, os pais disseram que a escola vivenciou algumas crises. Alguns coordenadores que eram "famosos" e reconhecidos foram demitidos, causando um grande mal-estar entre pais e alunos. Cláudia, a filha mais velha, chegou a frequentar as aulas com uma tarja preta no braço, de "luto" por essas medidas. Para a mãe "foi lindo! porque, claro, tem que se manifestar!". Entretanto, para todos foi difícil compreender e aceitar. Não chegaram, nessa época, a pensar em tirar os filhos porque acharam que outras escolas com proposta semelhante estavam vivendo situações parecidas, "era um processo geral". Mas houve uma evasão significativa de alunos, segundo a mãe. 
Em situações disciplinares com os alunos, eles identificaram também uma contradição entre um discurso democrático e ações autoritárias. Uma vez sua filha ficou inconformada com a expulsão de um colega e Karina foi à escola conversar para entender melhor o que tinha acontecido, e lhe foi dito que aquela era "uma prerrogativa da escola", sem maiores explicações. Porém, o pai pondera que a escola não conta todos os pormenores para não expor o aluno e a sua família. $O$ fato de a coordenação e a direção serem consideradas "chatas" e de se ter estabelecido um "padrão um pouco mais rigoroso de autoridade" começou a acontecer depois da fusão, mas também coincidiu com a entrada dos filhos na adolescência, quando se tornam mesmo mais questionadores. Por certo essa rebeldia dos filhos se reflete nos pais: "crianças rebeldes, pais nervosos!", que também se mostram resistentes e críticos.

Ambos gostam das reuniões de pais, embora Márcio dissesse que "ele se cansa um pouco" e, como tem um pouco mais de atividades à noite, vai menos. Já a mãe "acha inadmissível não ir" e questiona um pouco a postura do marido, dizendo que "quando vai, fica contente". Para Márcio, a qualidade das reuniões depende um pouco da pessoa responsável pela sua condução. Ele gosta muito das reuniões do Ensino Médio porque o coordenador é muito bom e aprende muito: "Ele fala e eu babo"! Também gosta de ouvir os professores. Mas, especialmente as reuniões de uma determinada coordenadora ele não gostava porque ela não era espontânea. Não que falasse coisas com as quais não concordava, mas a forma com que expunha era muito "artificial e chata".

Para Karina, apesar dessa coordenadora específica, as reuniões sempre foram muito "elucidativas [...] e cumpriam o papel a que se dispunham". Mostravam "a rotina que ia transcorrer", os professores relatavam seu trabalho e também se expunha os estudos do meio, de tal modo que possibilitava a ela acompanhar melhor o aprendizado dos filhos, especialmente do Daniel, que comenta muito pouco sobre o que está acontecendo na escola. Entretanto, ela concorda com o marido que eventualmente outros pais trazem questões para a reunião que não são pertinentes e que isso é desagradável.

Quando pergunto sobre como acompanham o estudo do filho, o pai diz que essa "é uma coisa difícil", pois a escola adota uma postura de que é o aluno o responsável 
pelo seu estudo e que os pais não devem interferir. E aí é que fica complicado, porque, se é assim, ele não deve nem cobrar a lição de casa, mas, ao mesmo tempo, se o filho deixa de fazer três, chega uma notificação em casa para eles assinarem. De modo que ele fica na dúvida: “Deixo o cara se estrepar?". Esse é um assunto que, volta e meia, outros pais levam para as reuniões. Karina admite que não segue a orientação de não interferir, pois, quando percebe que o filho está com dificuldade, procura ajudá-lo, estudando junto, orientando nos trabalhos, etc. Em síntese, acompanham a distância e, quando percebem que isso está prejudicando o aproveitamento do filho, ajudam e incentivam.

“O filho é um bom aluno?', perguntei. Pai e mãe discordam. Para a mãe, sim, porque, apesar de não ter boas notas em todas as matérias e de ser desorganizado, ele acaba se recuperando. Já o pai disse que ele bagunça um pouco na aula, e várias vezes foram chamados pelo coordenador por isso, além de ser muito preguiçoso para estudar. Entretanto, ambos reconhecem que o filho é articulado, escreve bem e tem um talento especial para o desenho desde pequeno. Nunca discordaram de algum encaminhamento da escola: "Sempre estavam certos". Todas as vezes que foram chamados ou que marcaram reuniões, "a abordagem deles foi muito positiva, nunca encaramos como uma maneira de confronto, sempre achamos bom", o que aumentou a confiança no trabalho deles.

Ao final a mãe disse que tem dúvida se é bom para os filhos passarem toda a vida escolar na mesma escola, já que as relações sociais ficam mais restritas. Ela, que estudou em escola pública, teve contato com uma diversidade maior de pessoas. Mas o pai é categórico em dizer que a vivência social dos filhos, apesar de ser restrita a uma classe social, é muito rica. Além disso, observa que ambos têm amizades muito sólidas. O filho, inclusive, por características dele, relaciona-se com outros grupos além do da escola. Diferente da sua própria experiência, em que "odiava a escola" e não fez amigos; só foi ter vida social na universidade. 